UNIVERSIDADE DE SÃO PAULO

INSTITUTO OCEANOGRÁFICO

ANDRÉ DA SILVA SALVATERRA

A investigação geotécnica como subsídio ao estudo da evolução quaternária de planícies costeiras

São Paulo 


\section{A investigação geotécnica como subsídio ao estudo da evolução quaternária}

\section{de planícies costeiras}

\section{Versão Corrigida}

Dissertação apresentada ao Instituto Oceanográfico da Universidade de São Paulo, como parte dos requisitos para obtenção do título de Mestre em Ciências, área de Oceanografia Geológica.

Orientador: Prof. Dr. Michel Michaelovitch de Mahiques

São Paulo 
Este exemplar foi revisado e corrigido em relação à versão original, sob responsabilidade única do autor e com a anuência de seu orientador.

São Paulo, de de

Assinatura do Autor:

Assinatura do Orientador:

Autorizo a reprodução e divulgação total ou parcial deste trabalho, por qualquer meio convencional ou eletrônico, para fins de estudo e pesquisa, desde que citada a fonte.

\section{Catalogação na publicação}

Instituto Oceanográfico da Universidade de São Paulo

Salvaterra, André da Silva

A investigação geotécnica como subsídio ao estudo da evolução quaternária de planícies costeiras / André da Silva Salvaterra; orientador, Michel Michaelovitch de Mahiques. - 2018 75 f.: il. + 1 DVD

Dissertação (Mestrado em Ciências) - Programa de Pós-Graduação em Oceanografia Geológica, Instituto Oceanográfico, Universidade de São Paulo, São Paulo, 2018 Versão corrigida

1. MIS3; Pleistoceno Superior; Nível do mar; Transgressão marinha; Planície costeira; Sondagens SPT; Baixada Santista. 


\section{AGRADECIMENTOS}

À Tati, Júlia e Felipe pelo apoio, companhia e carinho em todos os momentos.

Ao Prof. Dr. Michel Michaelovitch De Mahiques por sua orientação, paciência e disponibilidade durante a execução deste trabalho.

À empresa GEO-PRO por disponibilizar as sondagens, sem as quais, este trabalho não seria possível.

A todos os professores, funcionários e estagiários do Instituto Oceanográfico, Instituto de Geociências e Escola Politécnica da Universidade de São Paulo que contribuíram com a minha formação acadêmica. 


\section{RESUMO}

A partir da avaliação de um banco de dados com 192 sondagens SPT realizadas na costa do Estado de São Paulo, foram detalhadas neste trabalho duas perfurações executadas na planície costeira da RMBS, Município de São Vicente, litoral sudeste do Brasil, com objetivo de contribuir com o estudo estratigráfico regional, apresentando a descrição macroscópica, $\mathrm{N}_{\mathrm{SPT}}$, resultados granulométricos, geoquímicos e geocronológicos que indicam a correlação de depósitos lamosos amostrados em profundidade nestes furos com eventos transgressivos marinhos regionais. Tais resultados permitiram o reconhecimento de depósitos lamosos associados ao Estágio Isotópico Marinho 3 (MIS3) com idades entre 44890 AP e 40950 AP, formados em ambiente mixohalino desenvolvido entre 7 e 19 m abaixo do nível do mar atual, tendo-se ainda, proxies geoquímicos que sugerem uma transgressão marinha (ou mudança climática) entre 43000 e 42000 AP. Os resultados de granulometria indicaram o predomínio de areia fina nos intervalos arenosos e silte grosso nos lamosos, com $\mathrm{N}_{\mathrm{SPT}}$ das areias entre 2 e 40 e $\mathrm{N}_{\mathrm{SPT}}$ das lamas entre 1 e 8 , sendo que para as areias os números mais elevados estão relacionados aos depósitos com melhor seleção granulométrica, possivelmente, pela ação de dunas e/ou posicionadas inferiormente na coluna estratigráfica (e/ou próximas à base de cada intervalo), e para as lamas os maiores valores são encontrados nas porções inferiores das sondagens, provavelmente, devido ao peso da coluna sedimentar sobrejacente. Os resultados de diâmetro médio $(\varphi), \mathrm{N}_{\mathrm{SPT}}$ e $\mathrm{CaCO}_{3}$ apresentaram correlação em ambas as sondagens, observando-se para os maiores valores de $\varphi$, os menores de $\mathrm{N}_{\mathrm{SPT}}$ e os maiores de $\mathrm{CaCO}_{3}$. A distribuição dos metais na sondagem SP-02 revelou a existência de dois grupos principais, sendo o primeiro associado à dominância de minerais argilosos ( $\mathrm{K}, \mathrm{Ba}, \mathrm{Sc}, \mathrm{Al}, \mathrm{Mg}$ e $\mathrm{Sr})$, e o segundo, associado a óxidos ( $\mathrm{Fe}, \mathrm{Ti}, \mathrm{Cr}, \mathrm{V}, \mathrm{Mn}, \mathrm{Cu}, \mathrm{Ni}$ e $\mathrm{Zn}$ ), com a sequência basal lamosa (MIS5e) associada à fácies terrestre, e, as lamas intermediárias (MIS3) associadas a um ambiente mixohalino, indicando a possibilidade de rochas-fonte distintas ou mudanças nas condições climáticas entre MIS5e e MIS3.

Palavras-chave: MIS3; Pleistoceno Superior; nível do mar; transgressão marinha; planície costeira; sondagens SPT; Baixada Santista. 


\begin{abstract}
In this work, new evidence regarding a Marine Isotope Stage 3 (MIS3) transgression on the south-eastern Brazilian coast (Baixada Santista coastal plain) is shown. Data collected from two Standard Penetration Test (SPT) drillings allowed the distinction of four sandy intervals of three mud intervals, with the intermediate sequences revealing the occurrence of myxohaline sediments between BP 45,000 and 41,000 BP. A deeper sequence, which shows a clear transition from terrestrial to a myxohaline environment, was associated with the MIS5e. Organic and inorganic proxies have been used to recognize the variations on the terrestrial/myxohaline/marine deposits, as well as to infer about climate and energy of the depositional environment. Environmental change, which could correspond to a sea-level peak or the occurrence of drier conditions, was recognized between 43,000 and 42,000 BP. The SPT values in the sands varied between 2 and 40, while for muds the SPT values ranged from 1 to 8 . The results of mean diameter $(\varphi)$, SPT and $\mathrm{CaCO}_{3}$ presented a correlation in both drillings, with the highest values of $\varphi$, being the lowest of SPT and the highest of $\mathrm{CaCO}_{3}$. The results reinforce the need for future works on MIS3 variability on the South American Atlantic coast.
\end{abstract}

Keywords: Marine Isotope Stage 3; Late Pleistocene; sea-level; drillings; Standard Penetration Test; Brazilian coast. 


\section{LISTA DE ILUSTRAÇÕES}

Figura 1 - Planícies costeiras do litoral centro-sul do Estado de São Paulo............................ 15

Figura 2 - Fatores que controlam o nível relativo dos oceanos e dos continentes................... 17

Figura 3 - Curva de variação do NRM nos últimos 7000 anos, litoral trecho Santos-Bertioga.

Figura 4 - Área de estudo e sondagens avaliadas na RMBS, município de São Vicente/SP...24

Figura 5 - Região Metropolitana da Baixada Santista. ......................................................25

Figura 6 - Caminhos e trilhas feitas pelos índios entre São Vicente e o planalto....................27

Figura 7 - Mapa hipsométrico da costa central do Estado de São Paulo e escudo continental adjacente. Em detalhe, a área de estudo e as duas sondagens avaliadas. ...............................28

Figura 8 - Mapa geológico da RMBS................................................................................29

Figura 9 - Equipamento básico de sondagem de simples reconhecimento com SPT.............33

Figura 10 - Perfis das sondagens geotécnicas SP-02 e SP-05. ................................................39

Figura 11 - (A) Cotas/perfil; (B) Diâmetro médio dos grãos $(\varphi)$; (C) $\mathrm{N}_{\mathrm{SPT}}$; (D) Descrição da

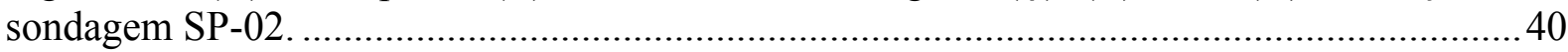

Figura 12 - Percentual por classe granulométrica para cada intervalo da sondagem SP-02 ... 43

Figura 13 - Histogramas de granulometria da sondagem SP-02 por intervalo arenoso. .........44

Figura 14 - Histogramas de granulometria da sondagem SP-02 por intervalo lamoso. ...........44

Figura 15 - Variações verticais de fatores 1 (53\% de variância explicada) e 2 (34,2\% de variância explicada) dos dados de granulometria. Distribuições de tamanho de grão são

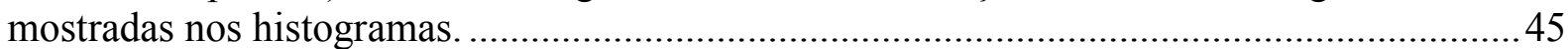

Figura 16 - Conteúdo de $\mathrm{CaCO}_{3}$ ao longo da sondagem SP-02 ............................................ 46

Figura 17 - Análise R-mode cluster (Coeficiente de Correlação, UPGMA clustering) de

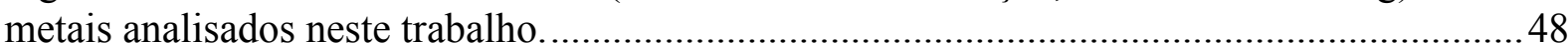
Figura 18 - Variações em $(\mathrm{A}) \delta^{13} \mathrm{C}$; (B) razão N/C; (C) $\ln (\mathrm{Ti} / \mathrm{Ca}) ;(\mathrm{D}) \ln (\mathrm{Fe} / \mathrm{K}) ;(\mathrm{E}) \ln (\mathrm{Ti} / \mathrm{Al})$; (F) $\ln$ (razão metais) ao longo da sondagem SP-02.

Figura 19 - (A) Cotas/perfil; (B) Diâmetro médio dos grãos $(\varphi)$; (C) $\mathrm{N}_{\mathrm{SPT}}$; (D) Descrição da

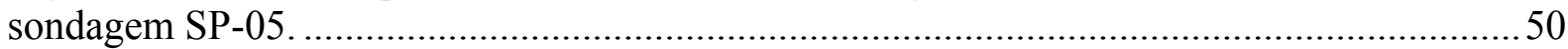

Figura 20 - Percentual por classe granulométrica para cada intervalo da sondagem SP-05...52

Figura 21 - Histogramas da granulometria da sondagem SP-05 por intervalo arenoso. .........53

Figura 22 - Histogramas da granulometria da sondagem SP-05 por intervalo lamoso. ..........54

Figura 23 - Perfil geológico esquemático da planície costeira na Baixada Santista................57

Figura 24 - Plotagem da dispersão das datações de sedimentos mixohalinos em profundidade.

Em verde (De Mahiques et al., 2011), em azul (Silva et al., 2014b) e em vermelho este

trabalho.

Figura 25 - (A) Locação das sondagens; (B) Perfil geológico entre as sondagens SP-02 e SP-

05 ao longo da Rodovia dos Imigrantes - SP-160 em São Vicente/SP. 


\section{LISTA DE TABELAS}

Tabela 1 - Características gerais dos sedimentos na planície sedimentar santista..................30

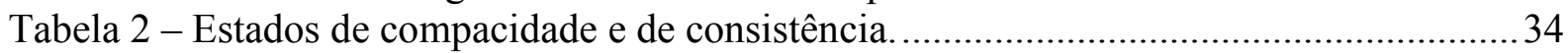

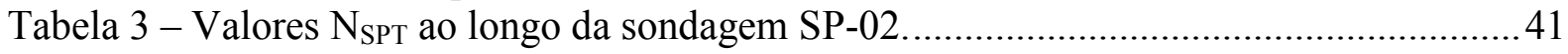

Tabela 4 - Datação por radiocarbono de amostras lamosas da sondagem SP-02 ...................42

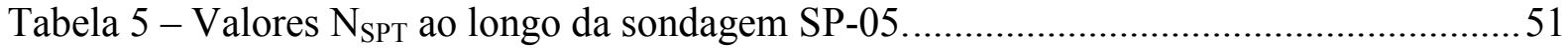




\section{LISTA DE ABREVIATURAS E SIGLAS}

\begin{tabular}{|c|c|}
\hline ABGE & Associação Brasileira de Geologia de Engenharia e Ambiental \\
\hline ABNT & Associação Brasileira de Normas Técnicas \\
\hline $\mathrm{AM}$ & Amostra \\
\hline AMS & Accelerator Mass Spectrometry \\
\hline AP & Antes do Presente \\
\hline AT & Aterro \\
\hline ATs & Argilas Transicionais \\
\hline $\mathrm{BP}$ & Before Present \\
\hline DER & Departamento de Estradas de Rodagem \\
\hline ESR & Electron Spin Resonance \\
\hline GPR & Ground Penetration Radar \\
\hline IA & Intervalo Arenoso \\
\hline IAEA & International Atomic Energy Agency \\
\hline IGC & Instituto Geográfico e Cartográfico do Estado de São Paulo \\
\hline IGEO & Interpretação Geológica \\
\hline IL & Intervalo Lamoso \\
\hline IOUSP & Instituto Oceanográfico da Universidade de São Paulo \\
\hline IPT & Instituto de Pesquisas Tecnológicas \\
\hline MIS3 & Marine Isotope Stage 3 \\
\hline MIS5e & Marine Isotope Stage 5e \\
\hline MS & Microsoft \\
\hline NBR & Norma Brasileira \\
\hline NOAA & National Oceanic and Atmospheric Administration \\
\hline NRM & Nível Relativo do Mar \\
\hline PA & Pavimento asfáltico \\
\hline $\mathrm{pMC}$ & Percent Modern Carbon \\
\hline $\mathrm{RM}$ & Razão de Metais \\
\hline RMBS & Região Metropolitana da Baixada Santista \\
\hline SAR & Solo de Alteração de Rocha \\
\hline SFL & Sedimentos Fluviolagunares \\
\hline $\mathrm{SH} 13$ & Southern Hemisphere Calibration \\
\hline SP & Sondagem à Percussão \\
\hline SPT & Standard Penetration Test \\
\hline SPT-T & Standard Penetration Test com torque \\
\hline UMG & Último Máximo Glacial \\
\hline USGS & United States Geological Survey \\
\hline UTM & Universal Transversa de Mercator \\
\hline
\end{tabular}




\section{LISTA DE SÍMBOLOS}

$\begin{array}{ll}\mathrm{cm} & \text { Centímetro } \\ \mathrm{C}_{\text {org }} & \text { Carbono Orgânico Total } \\ \delta^{13} \mathrm{C}_{\mathrm{PDB}} & \text { Razão Isotópica de }{ }^{13} \mathrm{C} \\ \delta^{15} \mathrm{~N}_{\mathrm{Ar}} & \text { Razão Isotópica de }{ }^{15} \mathrm{~N} \\ \mathrm{E} & \text { Leste } \\ \varphi & \text { Phi } \\ \mathrm{km} & \text { Quilômetro } \\ \mathrm{ln} & \text { Logaritmo Natural } \\ \mathrm{m} & \text { Metro } \\ \mathrm{NE} & \text { Nordeste } \\ \mathrm{N}_{\text {tot }} & \text { Nitrogênio Total } \\ \mathrm{N} / \mathrm{C} & \text { Relação Nitrogênio / Carbono } \\ \mathrm{N}_{\mathrm{SPT}} & \text { Número Standard Penetration Test } \\ \mathrm{SE} & \text { Sudeste } \\ \mathrm{SW} & \text { Sudoeste } \\ \mathrm{W} & \text { Oeste }\end{array}$




\section{AGRADECIMENTOS}

RESUMO

ABSTRACT

LISTA DE ILUSTRAÇÕES

LISTA DE TABELAS

LISTA DE ABREVIATURAS E SIGLAS

LISTA DE SÍMBOLOS

SUMÁRIO

1. INTRODUÇÃO

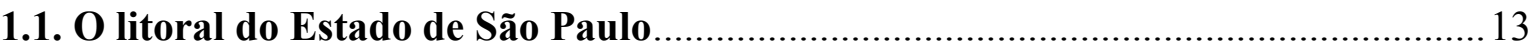

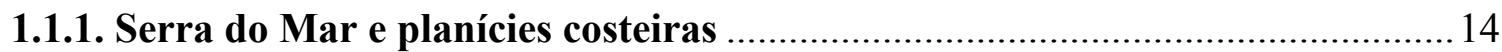

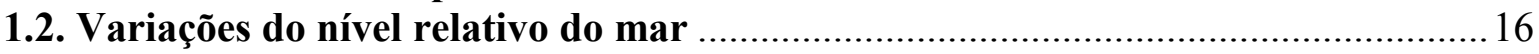

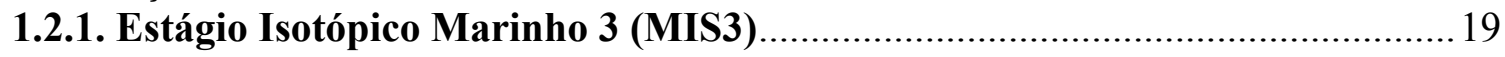

1.3. Considerações geológico-geotécnicas dos sedimentos quaternários ......................20

1.4. Sondagens SPT (Standard Penetration Test) para estudos sedimentares.............21

2. OBJETIVOS ...................................................................................................................... 23

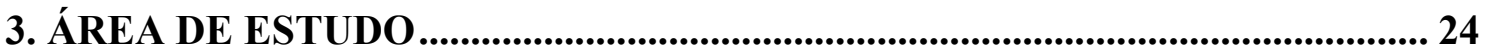

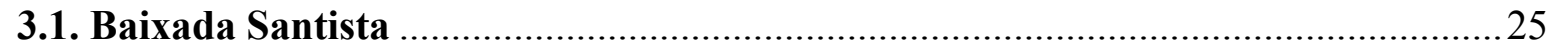

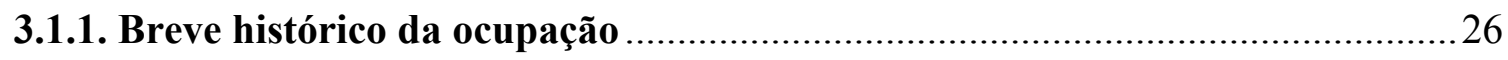

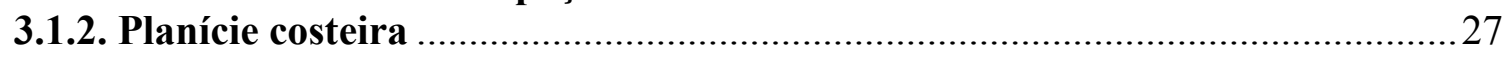

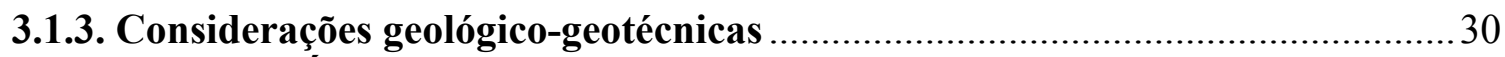

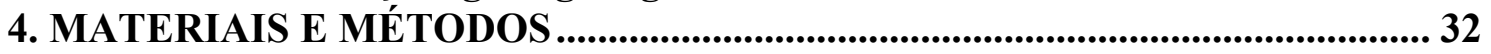

4.1. Sondagem de simples reconhecimento com SPT ….......................................... 33

4.2. Descrição macroscópica, elaboração dos perfis geológico-geotécnicos individuais e

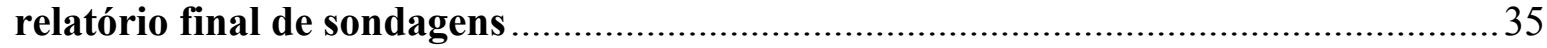

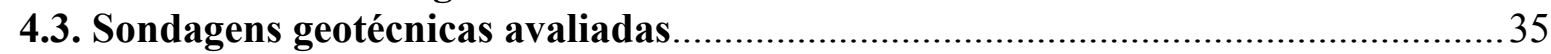

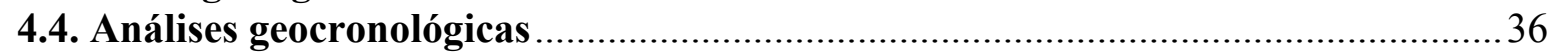

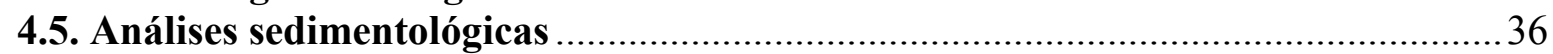

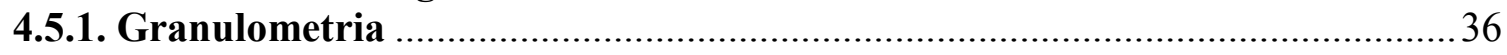

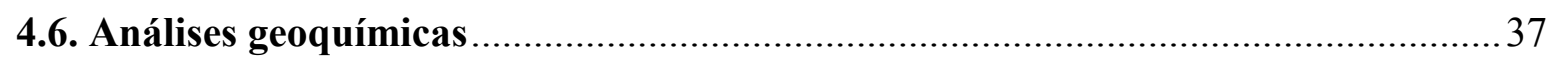



4.6.2. Conteúdo de Carbono orgânico $\left(C_{\text {org }}\right)$, Nitrogênio total $\left(N_{\text {tot }}\right)$, razão $\delta^{13} C_{P D B} e$

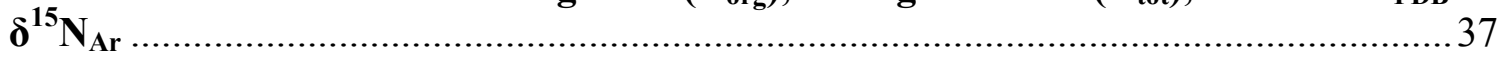

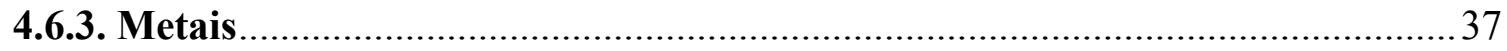

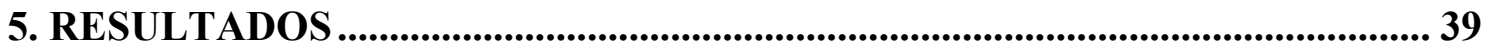

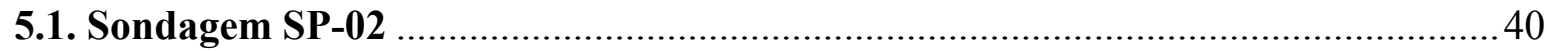

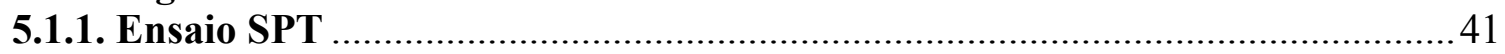

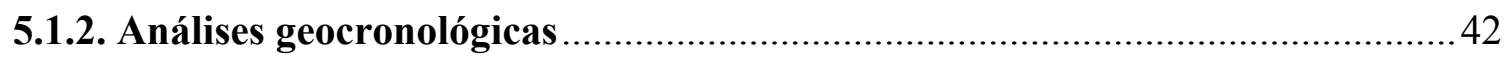

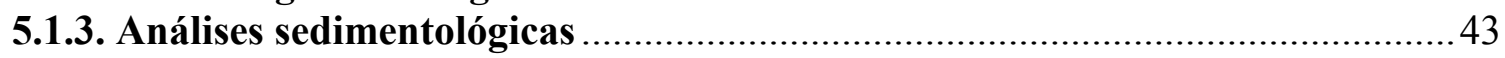

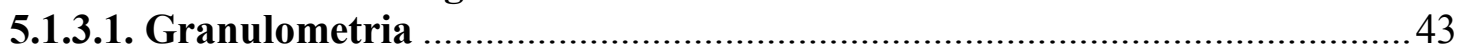

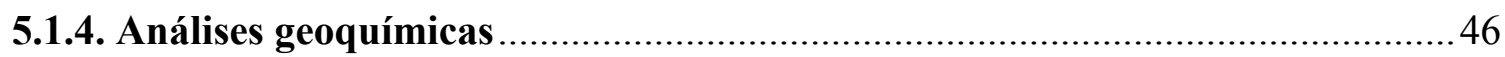

5.1.4.1. Conteúdo de Carbonato de Cálcio $\left(\mathrm{CaCO}_{3}\right)$.............................................46

5.1.4.2. Conteúdo de Carbono orgânico $\left(\mathbf{C}_{\text {org }}\right)$ e Nitrogênio total $\left(\mathbf{N}_{\text {tot }}\right) \ldots \ldots \ldots \ldots \ldots . . . . .47$

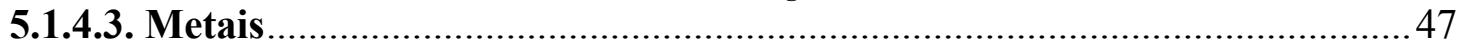


5.2. Sondagem SP-05

5.2.1. Ensaio SPT 50

5.2.2. Análises sedi

5.2.2.1. Granulometria

6. DISCUSSÃO

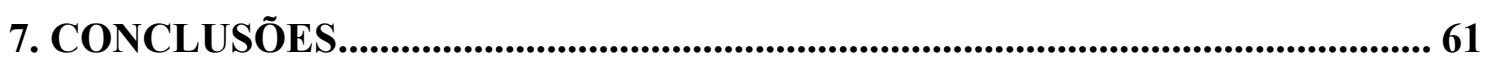

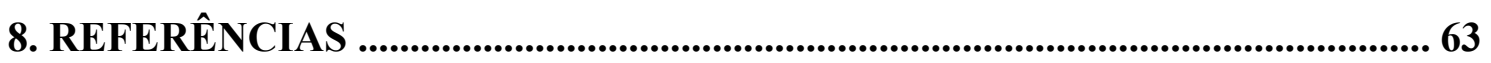

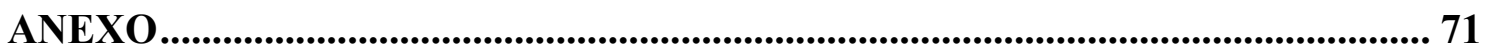

ANEXO A - Perfil sondagem geotécnica SP-02 ................................................... 72

ANEXO B - Perfil sondagem geotécnica SP-05..................................................... 74 


\section{INTRODUÇÃO}

No litoral sudeste do Brasil situam-se importantes cidades do país, muitas sobre depósitos sedimentares quaternários, originados da interação entre sistemas e processos costeiros diversos.

Com intenso movimento econômico e elevada ocupação populacional, centros metropolitanos costeiros como Santos, no Estado de São Paulo, ou Rio de Janeiro, no estado homônimo, demandam constantemente por obras civis, industriais e de infraestrutura, sendo necessário o prévio conhecimento geológico e geotécnico local e regional para o atendimento de tais solicitações.

Especificamente para a região costeira do Estado de São Paulo, os primeiros estudos geomorfológicos e arqueológicos de reconhecimento, e, com implicações ambientais, remontam ao final do século XIX (RODRIGUES et al., 1999).

O principal avanço no entendimento sobre a sedimentação no litoral paulista se deu a partir de trabalhos da década de 1960 e 1970, com o reconhecimento de diversos ambientes sedimentares e identificação das principais unidades geológicas e geomorfológicas quaternárias (SUGUIO; MARTIN, 1978a, 1978b; SUGUIO; BARCELOS, 1978).

Sob o ponto de vista geológico-geotécnico, os trabalhos iniciais sobre os sedimentos da planície costeira santista remontam à década de 1940, com estudos desenvolvidos pelo IPT para a construção de novas instalações portuárias para a CODESP, construção do trecho da Baixada da Via Anchieta e identificação da ocorrência de argilas distintas durante a construção das fundações de edifícios em Santos e São Vicente (VARGAS, 1999).

Somente na década de 1970, a questão sobre a origem destes depósitos sedimentares foi solucionada, a partir da aplicação do conceito de eustasia com expressão local relacionada às variações do nível relativo do mar, com diversos levantamentos sobre a posição de antigos níveis marinhos em um dado setor da costa, como no litoral noroeste da Europa, costa leste dos Estados Unidos e no Brasil (MÖRNER, 1969, 1976b; NEWMAN et al., 1980; SUGUIO et al., 1985 apud MASSAD, 2009; MARTIN et al., 1985; MARTIN et al., 1986).

\subsection{O litoral do Estado de São Paulo}

Dentro da divisão da costa brasileira (norte, nordeste, leste ou oriental, sudeste e sul) (SILVEIRA, 1964), o litoral sudeste, ou Litoral das Escarpas Cristalinas, apresenta como característica principal a proximidade da Serra do Mar e orientação NE-SW, estendendo-se do 
sul do Espírito Santo ao Cabo de Santa Marta (CUNHA; GUERRA, 2012). Diferentes macrocompartimentos foram identificados nesta faixa costeira: Litoral dos Cordões Litorâneos, Litoral das Escarpas Cristalinas Norte, Litoral das Planícies Costeiras e Estuários, Litoral das Escarpas Cristalinas Sul e Litoral das Planícies Litorâneas de Santa Catarina (MUEHE, 1998).

O litoral do Estado de São Paulo pode ser dividido, quanto à sua morfologia, em dois setores, observando-se a norte o embasamento em contato com o mar e ocorrência de pequenas planícies sedimentares, e, a sul, extensas planícies sedimentares formadas por depósitos marinhos e fluviolagunares, separadas entre si por pontões do embasamento em contato direto com o mar (SUGUIO; MARTIN, 1978a).

\subsubsection{Serra do Mar e planícies costeiras}

O sistema de montanhas representado pelas serras do Mar e da Mantiqueira, incluídas no Sistema de Rifts da Serra do Mar (ALMEIDA, 1976), renomeado como Rift Continental do sudeste do Brasil (RICCOMINI, 1989), segundo Almeida e Carneiro (1998, p. 135) "constitui a mais destacada feição orográfica da borda atlântica do continente sul-americano" estendendo-se do Rio de Janeiro ao norte de Santa Catarina, e, em São Paulo, impõe-se como típica borda de planalto, frequentemente nivelada pelo topo em altitudes de 800 a $1200 \mathrm{~m}$ (ALMEIDA; CARNEIRO, 1998).

Trabalhos clássicos atribuem o controle estrutural e a origem tectônica do relevo escalonado dos planaltos cristalinos do sudeste do Brasil (RUELLAN, 1944; FREITAS, 1951; ALMEIDA, 1964 apud CAMPANHA; ENS; PONÇANO, 1994). Em contrapartida, trabalhos com modelos erosivos e que atribuem aos movimentos tectônicos uma influencia secundária no modelamento do terreno, destacam a alternância entre ciclos áridos do terreno que passaram a ser dissecados e entalhados por drenagens em fases úmidas subsequentes, propiciando a instalação de novas superfícies pedimentares rebaixadas em relação às anteriores resultando, ao final de diversos ciclos, na formação de planaltos situados a altitudes distintas (BIGARELLA; AB'SABER, 1964; BIGARELLA; ANDRADE, 1965 apud CAMPANHA; ENS; PONÇANO, 1994).

Estudos mais recentes enfatizam o controle tectônico e reativações tectônicas tardias na evolução geológica cenozóica do sudeste do Brasil e da "Província Serra do Mar", esta última, de idade neocretácea e controlada por falhas de direção NE a ENE relacionadas ao 
desenvolvimento do acidente topográfico homônimo e da Bacia de Santos (RICCOMINI; SANT'ANNA; FERRARI, 2004).

A integração dos dados das bacias sedimentares associadas aos rifts revelou a presença de depósitos sedimentares do Pleistoceno Superior nas bacias de Resende e Taubaté também afetados por reativação de falhas relacionadas à tectônica transcorrente, fortemente indicativa de atividade neotectônica compressiva segundo E-W, aparentemente ativa até o presente, pelo menos como tectonismo residual (CAMPANHA et al., 1985; CAMPANHA; ENS; PONÇANO, 1994; MELO et al., 1985; RICCOMINI, 1989; RICCOMINI; SANT'ANNA; FERRARI, 2004; SALVADOR, 1994; ZALÁN; OLIVEIRA, 2005; RIBEIRO et al., 2011).

As planícies sedimentares mais desenvolvidas no litoral paulista ocorrem nos trechos Cananéia-Iguape, Itanhaém-Santos e parte de Bertioga (Figura 1), preenchidas por sedimentos quaternários (SUGUIO; MARTIN, 1978a, 1978b) associados a duas transgressões marinhas, uma ocorrida no Pleistoceno Superior (Transgressão Cananéia MIS5e) e outra no Holoceno Médio (Transgressão Santos) (SUGUIO; MARTIN, 1978a, 1978b). Aspectos da evolução e dos depósitos foram estudados por Suguio e Martin (1978a, 1978b) e Coelho et al. (2010).

Figura 1 - Planícies costeiras do litoral centro-sul do Estado de São Paulo.

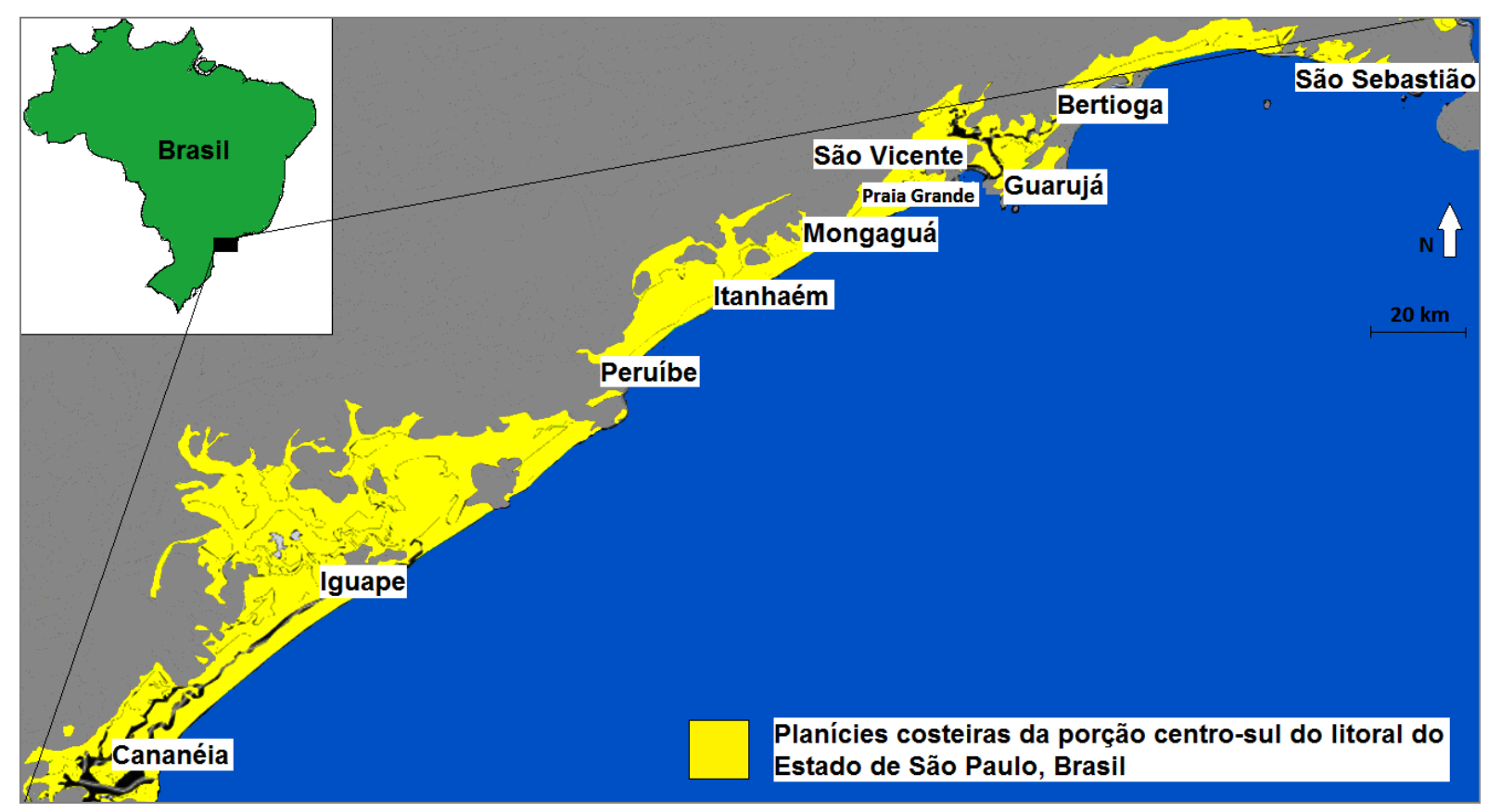

Fonte: Adaptado de (<http://portal.onegeology.org/OnegeologyGlobal/>, 2018).

Os sedimentos da Formação Cananéia, associados à transgressão homônima, foram depositados em ambiente mixohalino, descritos como depósitos transicionais (areias siltosas, 
argilas arenosas) de ambiente continental na porção inferior e ambiente marinho na parte superior (SUGUIO; PETRI, 1973), aparecendo como terraços arenosos de 6 a $7 \mathrm{~m}$ acima do nível do mar atual e argilas transicionais médias a rijas entre 15 e $35 \mathrm{~m}$ de profundidade (SUGUIO et al., 1978a; MASSAD, 2009).

Os sedimentos holocênicos caracterizam-se por terraços arenosos de construção marinha com altitudes de $4 \mathrm{~m}$ a $5 \mathrm{~m}$, por vezes revelando a ação de dunas, argilas fluviolagunares, muito moles a moles, e argilas de manguezais recentes, depositadas sobre as argilas fluviolagunares (SUGUIO; MARTIN, 1981; MASSAD, 2009; SUGUIO, 2010).

Um modelo geológico esquemático da planície costeira da Baixada Santista foi proposto por Suguio e Martin (1981) para explicar a origem destas planícies sedimentares durante o Quaternário em cinco estágios evolutivos, atribuída principalmente às variações do nível relativo do mar: 1 - deposição dos sedimentos transicionais argilo-arenosos e areias sobre os sedimentos continentais da Formação Pariquera-Açu, durante o máximo da Transgressão Cananéia, o qual atingiu o pé da Serra do Mar; 2 - Início da regressão marinha e deposição de cordões arenosos regressivos sobre os depósitos transicionais transgressivos, retrabalhados superficialmente pela ação dos ventos; 3 - erosão da Formação Cananéia originando vales profundos pela ação fluvial, atribuída à acentuada regressão marinha a cerca de 17000 AP com o nível relativo do mar chegando a $-110 \mathrm{~m}$ abaixo do atual, preservando, entretanto, os cordões arenosos formados preteritamente; 4 - novo avanço marinho em direção ao continente durante a Transgressão Santos, com penetração inicial da água do mar em zonas baixas e canais escavados durante a regressão anterior, originando um complexo sistema de lagunas e deposição de sedimentos argilo-arenosos ricos em matéria orgânica, ocorrendo ainda e em paralelo, a erosão por ação marinha das porções altas da Formação Cananéia e respectiva ressedimentação do material erodido, originando os depósitos marinhos arenosos holocênicos, e; 5 - formação dos cordões arenosos associados ao final da Transgressão Santos e recuo do mar à sua posição atual.

\subsection{Variações do nível relativo do mar}

As variações do nível relativo dos oceanos são controladas por tectono-eustasia, glacio-eustasia e geoido-eustasia (Figura 2), enquanto as mudanças nos níveis dos continentes ocorrem por movimentos tectônicos horizontais e verticais, movimentos isostáticos relacionados às variações nas sobrecargas exercidas pela expansão e retração das geleiras 
sobre os continentes e deformação das superfícies continentais, principalmente por fenômenos gravitacionais (MARTIN et al., 1986; SUGUIO, 2003, 2010).

Figura 2 - Fatores que controlam o nível relativo dos oceanos e dos continentes.

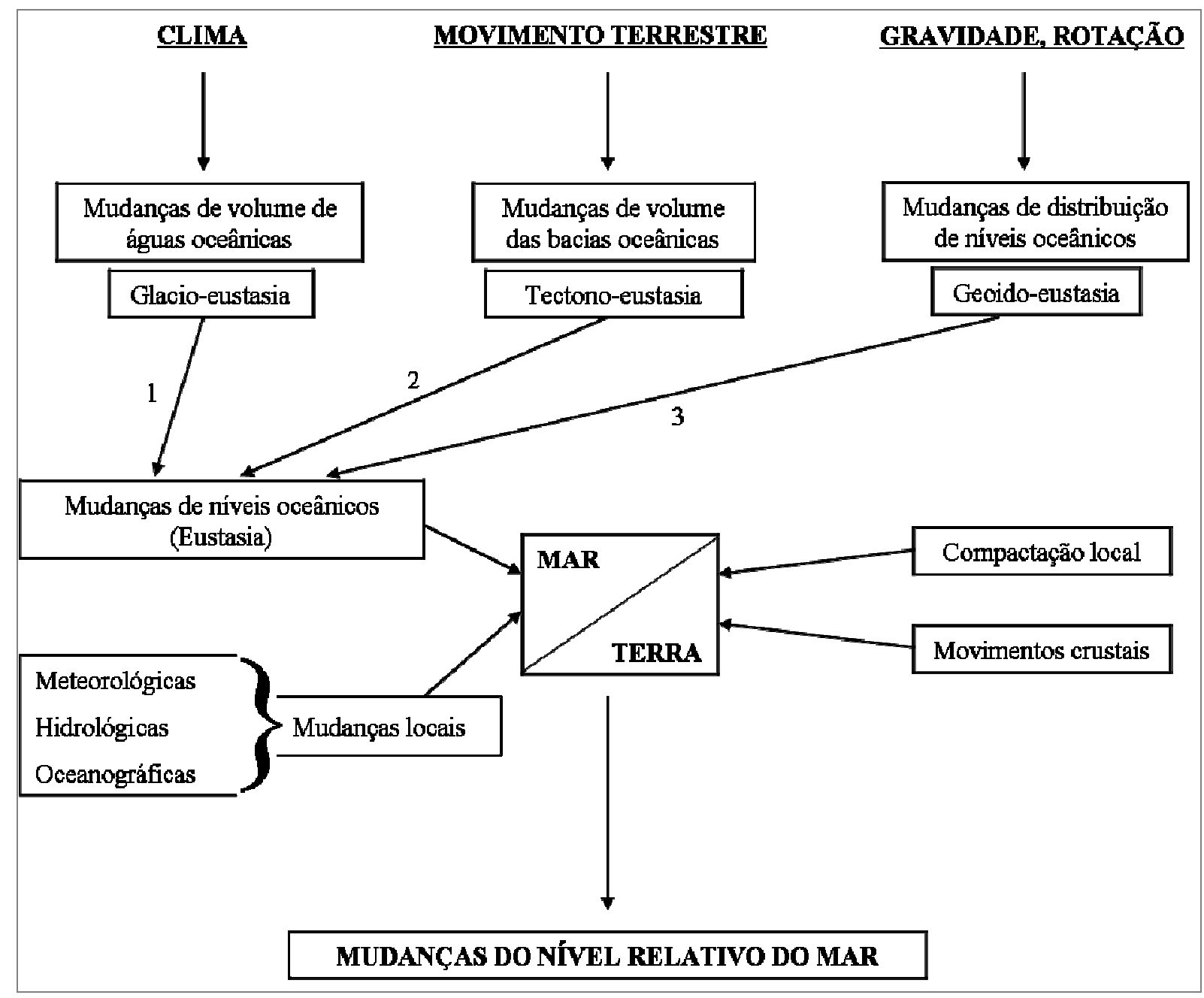

Fonte: Adaptado de (Martin et al., 1986).

Para Suguio (2010, p. 203) “o nível do oceano em um determinado ponto da costa é o produto instantâneo de complexas interações entre os níveis das superfícies do oceano e da terra emersa adjacente".

No mundo, as pesquisas sobre as variações do nível relativo do mar e mudanças nas linhas de costa remontam ao século XIX, e, no Brasil, somente a partir da década de 1970, o conhecimento deste campo de pesquisa progrediu devido principalmente à implantação do Projeto de Reconhecimento Global da Margem Continental Brasileira (MASSAD, 2009). 
O uso do conceito de eustasia com expressão local permitiu a confecção de curvas de variação do nível relativo do mar em diferentes litorais, trazendo luz sobre a origem dos sedimentos costeiros quaternários em todo o mundo (MARTIN et al., 1986; MASSAD, 2009).

De acordo com Suguio \& Martin (1978a), no litoral do Estado de São Paulo, durante o Quaternário, evidências de níveis marinhos mais elevados (Figura 3) foram relacionadas a dois eventos transgressivos, um ocorrido durante o Pleistoceno Superior (Transgressão Cananéia) com nível relativo $8 \mathrm{~m} \pm 2 \mathrm{~m}$ acima do atual e ápice em cerca de 120000 anos A.P. (MARTIN et al., 1983 apud MASSAD, 2009; SUGUIO, 2010), e outro, durante o Holoceno Médio (Transgressão Santos), iniciado em cerca de 18000 anos AP e máxima amplitude de 4,5 m acima do nível atual em cerca de 5100 anos AP, havendo, entretanto, uma oscilação negativa de -2 m, ocorrida por volta de 3900 anos AP (SUGUIO; MARTIN, 1978a, 1981; MASSAD, 2009). Angulo, Lessa \& Souza (2006) revisaram as mudanças no nível marinho durante o Holoceno Médio-Superior, definindo uma elevação máxima de 2 a 4 m em 5600 AP.

Figura 3 - Curva de variação do NRM nos últimos 7000 anos, litoral trecho Santos-Bertioga.

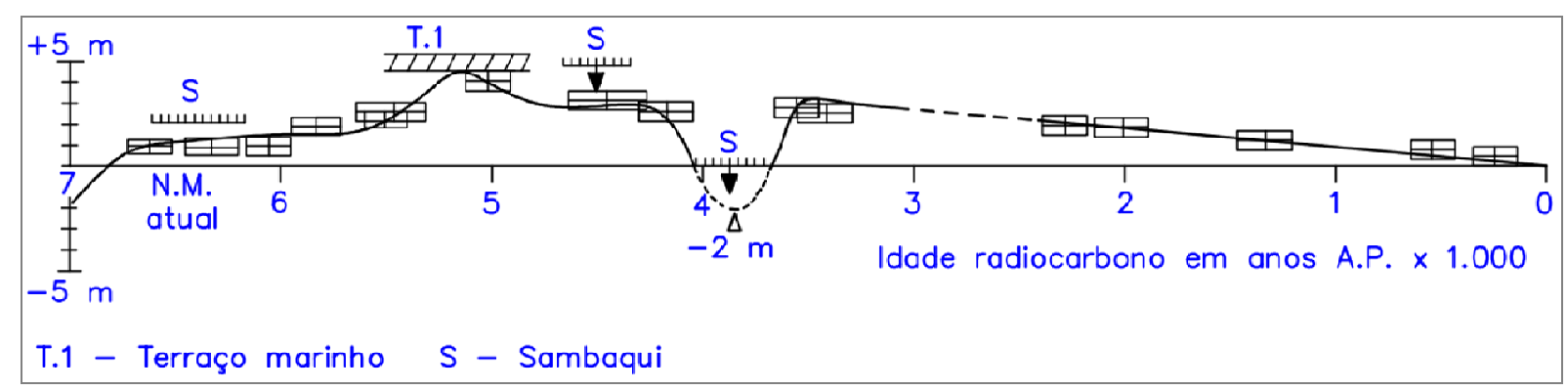

Fonte: Adaptado de (Suguio e Martin, 1981).

Por outro lado, há poucas informações a respeito da posição do nível marinho no leste e sudeste brasileiro entre o ótimo climático do MIS5e e o Holoceno Inferior (SALVATERRA et al., 2017).

Corrêa (1996) propôs uma curva do nível marinho entre o Último Máximo Glacial (UMG) e o Holoceno Inferior, baseada na posição dos terraços de abrasão do sudeste do Brasil com curvas de níveis marinhos globais. Vicalvi et al., (1978) reconheceu uma paleolaguna na Depressão de Abrolhos, datada de 10600 AP (data não calibrada). Finalmente, De Mahiques et al. (2011) apresentou quatro datações em diferentes materiais de "rochapraial" localizada a $13 \mathrm{~m}$ de altitude, com datação calibrada de 8200 AP. 
Entretanto, para Angulo, Lessa \& Souza (2006), o uso de datação por radiocarbono na construção de curvas de variação do nível marinho holocênico na costa leste brasileira levou a diversos resultados discrepantes e inconsistentes, não apenas em setores vizinhos, mas também, em diferentes estudos no mesmo setor costeiro, uma vez que uma grande parte dos dados (cerca de 70\%) foram inconclusivos ou mal interpretados, resultando em curvas erradas de variação do nível do mar, propondo então, o uso de vermitídeos como ideais para a reconstrução de curvas de nível marinho.

\subsubsection{Estágio Isotópico Marinho 3 (MIS3)}

A alternância entre períodos glaciais e interglaciais, durante o Quaternário, pode ser observada a partir do registro de isótopos de oxigênio (PISIAS et al., 1984), tendo-se desenvolvido uma escala de tempo baseada na razão isotópica de oxigênio em sedimentos profundos a partir de trabalhos pioneiros que consideraram dados obtidos nos oceanos Atlântico, Caribe e Pacífico (EMILIANI, 1955).

O Estágio Isotópico Marinho 3 (MIS3) corresponde a um intervalo de tempo entre 60000 e 25000 anos AP, com mudanças abruptas nas condições climáticas em escala milenar (SIDDALL et al., 2008), apresentando oscilações marinhas entre $30 \mathrm{~m}$ e $80 \mathrm{~m}$ abaixo do nível atual (CHAPPELL; SHACKLETON, 1986; LAMBECK; BARD, 2000; CHAPPELL, 2002; PAHNKE et al., 2003; RABINEAU et al., 2006). Variações de curto prazo em intervalos de 6000 a 7000 anos seguidos de eventos de subida de $10 \mathrm{~m}$ a 15 metros, correspondentes a eventos Heinrich, ocorreram neste intervalo de tempo (CHAPPELL, 2002).

Entretanto, diversos trabalhos reportaram a ocorrência de MIS3 em níveis consideravelmente mais altos do que os apresentados em curvas de níveis tradicionais (CANN et al., 1993; MURRAY-WALLACE et al., 1993; RODRIGUEZ et al., 2000; MURRAYWALLACE, 2002; HANEBUTH et al., 2006; SIMMS et al., 2009; DOĞAN et al., 2012).

Na América do Sul, outros exemplos de MIS3 foram descritos nas costas do Atlântico e do Pacífico (ISLA, 1990; ISLA; SCHNACK, 2016), mas parte destes dados foi descartada por comparação dos dados de radiocarbono com ESR (SCHELLMANN; RADTKE, 1997).

No Brasil, alguns trabalhos indicaram a ocorrência do MIS3 no litoral sudeste, através do reconhecimento de um ambiente lagunar, entre 47000 e 36000 anos AP na planície costeira de Maricá/RJ (SILVA et al., 2014a), bem como, um conjunto completo de idades coerentes de radiocarbono em matéria orgânica e foraminíferos entre 39000 e 24000 anos AP que marcam a transição de condições mixohalinas para águas interiores em ambiente raso (6 m) no Canal 
de São Sebastião/SP (DE MAHIQUES et al., 2011), e ainda, níveis marinhos mais elevados na plataforma continental do Estado do Paraná (SOUZA, 2005; VEIGA, 2005).

A principal crítica aos trabalhos que tratam do MIS3 está associada às limitações do radiocarbono como uma ferramenta geocronológica adequada, onde uma parte significativa deste evento não pode ser datada com confiança (após 45000 anos). Também, a contaminação de materiais mais antigos com carbono jovem pode resultar em datações MIS3 aparentes (MURRAY-WALLACE et al., 1993; YIM, 1999; HANEBUTH et al., 2006). Entretanto, a introdução da técnica de espectrometria de massa com acelerador de partículas (AMS) para a datação por radiocarbono (DORN et al., 1989) trouxe uma nova perspectiva para a datação radiocarbônica além de 30000 AP. Com isso, é possível que diversas amostras Pleistocênicas originalmente datadas em estudos na costa brasileira necessitem de revisão devido à possibilidade de estarem relacionadas à transgressão MIS3 (SALVATERRA et al., 2017).

\subsection{Considerações geológico-geotécnicas dos sedimentos quaternários}

Os sedimentos quaternários costeiros apresentam comportamento geotécnico diverso (mesmo para depósitos classificados em uma mesma classe granulométrica), com os primeiros trabalhos a respeito da geotecnia desses depósitos na costa paulista datados do final da década de 1940 (MASSAD, 2009).

A presença de diferentes argilas marinhas de consistência variável, em toda a planície costeira de Santos, bem como de argilas orgânicas moles na Baixada Fluminense e em outras partes do litoral brasileiro, constituiu um desafio para a Engenharia Nacional no que tange às construções civis, industriais e de infraestrutura (MASSAD, 2009).

Um importante aspecto relacionado ao comportamento dos solos da Baixada Santista é o recalque e desaprumo em prédios da orla com mais de 10 andares (construídos a partir da década de 1940), os quais, geralmente, foram fundados sobre a camada superficial de areia, e, devido ao peso da estrutura, a camada subjacente de lama acabou comprimida, acarretando no adensamento desta pela expulsão da água intersticial (VARGAS, 1999).

A compreensão da origem das planícies costeiras, determinada pelas variações do nível relativo do mar, durante o Quaternário, auxiliou no entendimento do sobreadensamento das argilas em bases puramente mecânicas (pressão total de terra, oscilação negativa do nível do mar durante os últimos 7000 anos, ação de dunas, movimentação de ilhas-barreira e envelhecimento) (MASSAD, 2009). 
Relacionado às variações marinhas e ao peso de dunas, o forte sobreadensamento nas argilas transicionais pleistocênicas e o leve a forte sobreadensamento nas argilas holocênicas de sedimentos fluviolagunares do litoral centro-sul paulista resultou em comportamentos geotécnicos diferenciados (MASSAD, 2009), ainda que tais sedimentos possam apresentar granulometria e mineralogia semelhantes (MELLO; PONÇANO, 1983).

É possível diferenciar as argilas transicionais das argilas de sedimentos fluviolagunares, por exemplo, com uso da medida obtida no SPT e SPT-T, com índices de SPT entre 0 e 4 para as argilas de sedimentos fluviolagunares e de 5 a 25 para as argilas transicionais (MASSAD, 2009).

Algumas vezes, as argilas de sedimentos fluviolagunares mostram-se homogêneas e uniformes, com provável deposição em ambiente calmo lagunar ou de baía. Outras vezes, aparecem com grande heterogeneidade e distribuição caótica, com provável deposição em ambiente conturbado, próximo à rede fluvial (MASSAD, 2009).

Em vista da complexidade dos materiais geológicos litorâneos, em especial, dos depósitos sedimentares quaternários encontrados na planície costeira da Baixada Santista, a implantação das fundações de quaisquer obras, deve, necessariamente, ser precedida de estudos de caracterização geológica e geotécnica, tanto nas encostas da Serra do Mar quanto na planície costeira quaternária, com destaque para o uso de sondagens de simples reconhecimento do subsolo com SPT, amplamente conhecidas e utilizadas no Brasil, devido à simplicidade na execução dos trabalhos, eficiência na obtenção e entrega dos resultados e baixo custo.

\subsection{Sondagens SPT (Standard Penetration Test) para estudos sedimentares}

“A sondagem à percussão ou sondagem de simples reconhecimento ou, ainda, sondagem com SPT é o processo de investigação mais comum empregado na caracterização da cobertura terrosa dos terrenos naturais" (SOUZA; DA SILVA; IYOMASA, 1998, p. 185). Este método, apesar de relativamente simples e com baixo custo, é eficaz para a medida da resistência de solos e coleta de amostras, definindo o tipo de solo e suas características geotécnicas em profundidade.

Diversos trabalhos com enfoque geotécnico sobre argilas e areias litorâneas quaternárias obtidas em sondagens foram feitos a partir de 1960 (MASSAD, 2009), não caracterizando, entretanto, os sedimentos quanto a análises sedimentares, geoquímicas e geocronológicas. 
Suguio e Martin (1978b) utilizaram perfis de sondagens de simples reconhecimento com SPT para a construção de seções geológicas na área da planície costeira santista, com enfoque nas características geológicas dos sedimentos, evolução e na estratigrafia regional (MASSAD, 2009).

Dorneles, Becker e Dillenburg (2006) estudaram as variações granulométricas dos sedimentos da barreira holocênica do Rio Grande do Sul com a execução de nove sondagens SPT ao longo de três perfis transversais à barreira.

Dillenburg et al. (2007) estudaram a Barreira Costeira de Dunas Altas no litoral médio do Estado do Rio Grande do Sul, de idade holocênica, a partir de dados de duas sondagens SPT associados a estudos morfológicos da barreira.

Lima (2008) estudou a estratigrafia e a evolução da barreira holocênica na praia do Hermenegildo, Estado do Rio Grande do Sul, através da integração de dados de três sondagens SPT associadas a métodos geofísicos.

Yanez e Gonçalves (2010) estudaram as argilas marinhas da região do Porto de Santos, Estado de São Paulo, e suas características geotécnicas com uso de diversas sondagens SPT.

Dillenburg et al. (2011) utilizaram uma sondagem de simples reconhecimento com SPT e GPR para estudos sedimentares e datação por radiocarbono em sedimentos quaternários regressivos na costa do Estado de Santa Catarina.

Lima et al. (2011) utilizaram perfilagens com GPR associadas a duas sondagens SPT para o detalhamento da zona de transição entre a fase transgressiva e regressiva da barreira costeira holocênica ao longo do litoral norte do Estado do Rio Grande do Sul.

Caron et al. (2011) estudaram barreiras transgressivas costeiras holocênicas do Estado do Rio Grande do Sul através da comparação de registros de GPR e dados de uma sondagem SPT. 


\section{OBJETIVOS}

Este trabalho tem como objetivo contribuir com o estudo da evolução quaternária de planícies costeiras a partir do uso de dados e amostras obtidas em duas sondagens geotécnicas com SPT, as quais foram realizadas na porção centro-sul do litoral do Estado de São Paulo. Tal contribuição envolve:

- Caracterização sedimentológica e geotécnica das areias e lamas quaternárias da planície costeira na Região Metropolitana da Baixada Santista (RMBS), originalmente associadas a dois eventos transgressivos marinhos conhecidos no litoral paulista (Transgressão Cananéia e Transgressão Santos);

- Caracterização geoquímica e datação por radiocarbono de sedimentos lamosos em profundidade, possivelmente associados aos eventos transgressivos MIS5e e MIS3;

- Contribuição ao estudo estratigráfico regional, especificamente ao perfil geológico esquemático da planície costeira da RMBS proposta por Suguio \& Martin (1978b). 


\section{3. ÁREA DE ESTUDO}

A área de estudo (Figura 4) situa-se na porção centro-sul do litoral do Estado de São Paulo, região sudeste do Brasil, entre as latitudes $23^{\circ} 38^{\prime} \mathrm{S}$ e $24^{\circ} 26^{\prime} \mathrm{S}$ e longitudes $45^{\circ} 47^{\prime} \mathrm{W}$ e $47^{\circ} 07^{\prime} \mathrm{W}$, inserida no compartimento do litoral conhecido como Região Metropolitana da Baixada Santista (Município de São Vicente), a qual é recoberta por depósitos sedimentares continentais, marinhos e de dunas do Pleistoceno Superior e sedimentos transicionais e lagunares do Holoceno, adicionalmente, por depósitos aluviais modernos próximos à Serra do Mar (SUGUIO; MARTIN, 1978b).

Figura 4 - Área de estudo e sondagens avaliadas na RMBS, município de São Vicente/SP.

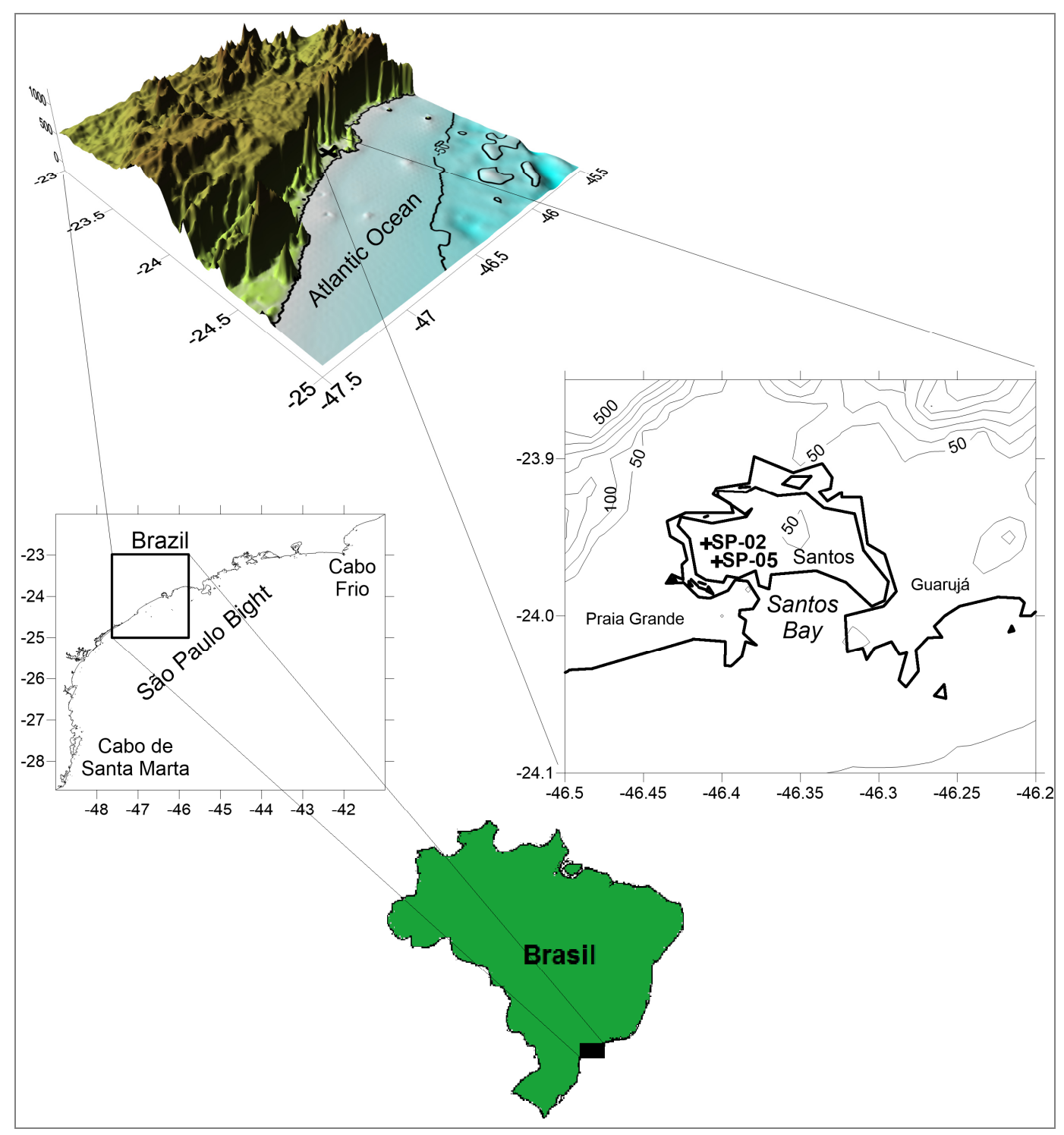

Fonte: Adaptado de (Salvaterra et al., 2017). 


\subsection{Baixada Santista}

A RMBS é composta pelos municípios de Bertioga, Cubatão, Guarujá, Itanhaém, Mongaguá, Peruíbe, Praia Grande, Santos e São Vicente (Figura 5), cobrindo uma área de $2420,5 \mathrm{~km}^{2}$, população de 1.828 .212 habitantes e densidade demográfica de $755,31 \mathrm{hab} . / \mathrm{km}^{2}$ (EMPRESA PAULISTA DE PLANEJAMENTO S/A., 2017), apresentando relevante importância econômica devido, principalmente, à presença do parque industrial de Cubatão e do complexo portuário de Santos, ativo desde 1892 (COMPANHIA DOCAS DO ESTADO DE SÃO PAULO, 2017).

Figura 5 - Região Metropolitana da Baixada Santista.

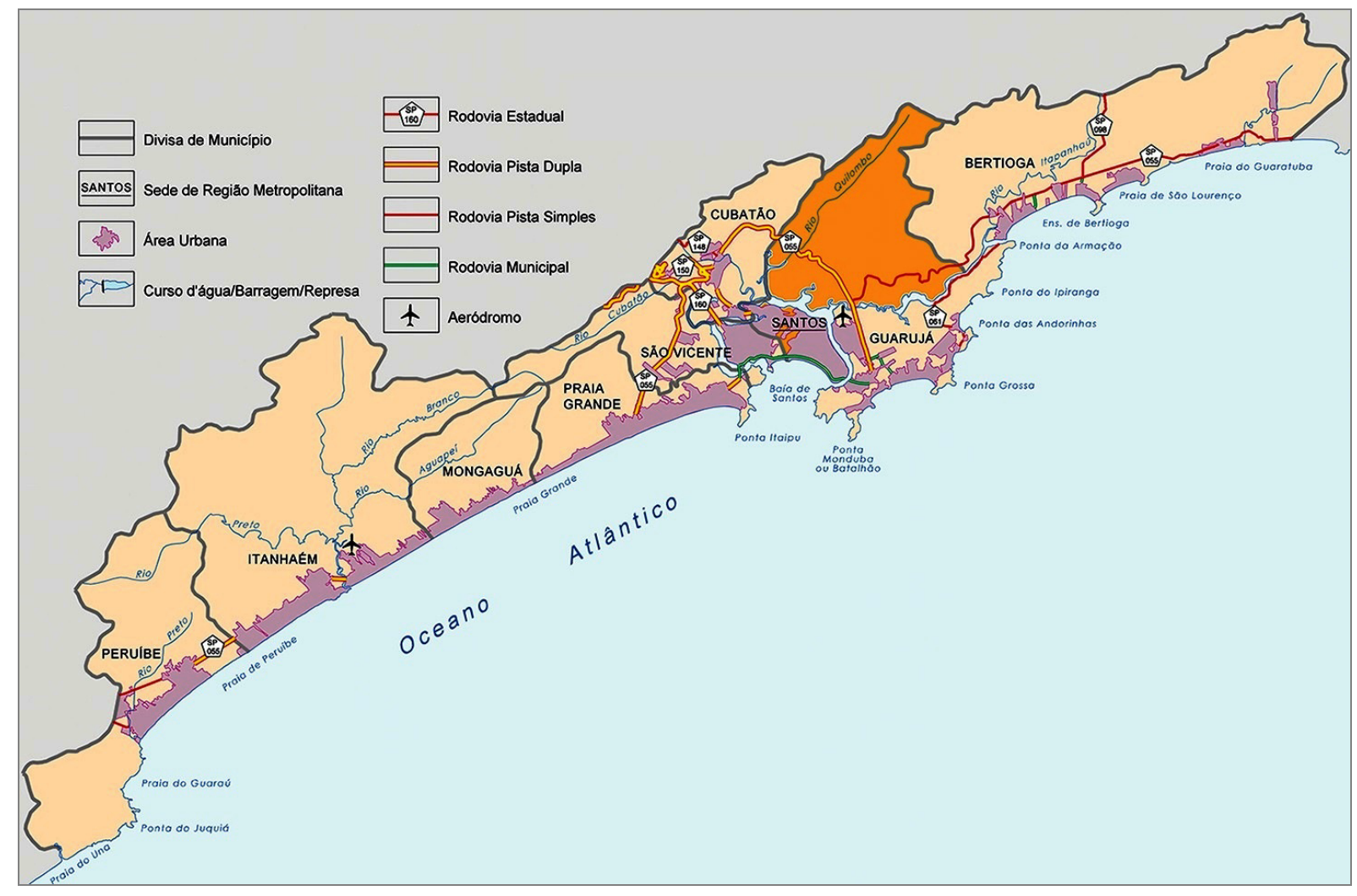

Fonte: DER - Mapa Rodoviário do Estado de São Paulo (2006); IGC - Divisão Municipal do Estado de São Paulo (1998).

Uma elevada demanda por obras na RMBS ocorre devido às atividades portuárias, industriais, petrolíferas, população e intensa movimentação rodoviária no Sistema AnchietaImigrantes, principal ligação entre as regiões metropolitanas de São Paulo e da Baixada Santista. Composto pelos trechos SP-150 - Rodovia Anchieta, SP-160 - Rodovia dos Imigrantes, SP-040/150 - Interligação Planalto, SP-059/150 - Interligação Baixada, SP- 
248/055 - Rodovia Cônego Domenico Rangoni e SP-055 - Rodovia Padre Manoel da Nóbrega, o Sistema Anchieta-Imigrantes totaliza 176,44 km de estradas (ECORODOVIAS INFRAESTRUTURA E LOGÍSTICA S/A, 2018), dos quais, aproximadamente $99 \mathrm{~km}$ atravessam a área de planalto e serra e $77 \mathrm{~km}$ cortam a planície costeira, exigindo um constante monitoramento geotécnico de túneis, pavimentos e obras de arte instaladas na serra e na planície costeira.

Nos terrenos baixos, estabeleceu-se um complexo de canais estuarinos margeados por vegetação pantanosa, enquanto que as porções arenosas mais elevadas estão ocupadas atualmente pela infraestrutura urbana, industrial e portuária da RMBS.

\subsubsection{Breve histórico da ocupação}

Desde a ocupação do litoral do atual Estado de São Paulo pelos "homens dos sambaquis", passando pelos índios e colonização portuguesa, até os dias atuais, a transposição da Serra do Mar a partir do Estuário de Santos em direção ao Planalto Paulista mostrou-se uma tarefa complexa, seja pela dificuldade pretérita em atravessar a serra e a densa Mata Atlântica com o uso de animais e o auxílio dos índios na abertura de trilhas e caminhos (Figura 6), seja pelo ponto de vista geotécnico atual, com a construção e manutenção das modernas instalações rodoviárias e ferroviárias presentes na região.

Evidências de povoação do litoral anterior à dos índios estão relacionadas com a descoberta de sambaquis (acumulações de conchas, restos humanos, ossos de peixes de aves), construídos pelos "homens dos sambaquis" (VARGAS, 1999). Até o final do século XV, esta faixa costeira era povoada por índios tupis, com os primeiros colonizadores portugueses instalando-se na região em 1493, provavelmente tripulantes da armada de Francisco de Almeida (PREFEITURA MUNICIPAL DE SÃO VICENTE, 2013).

A ocupação definitiva remonta ao início do processo de colonização do território brasileiro, tendo como marco fundamental a Vila de São Vicente, fundada em 1532, a mais antiga urbanização do Brasil, com economia baseada na agricultura e mercantilismo (ZÜNDT, 2006).

Logo após a fundação, buscou-se para a vila um ponto mais abrigado para a atracação das caravelas, encontrando-se do outro lado da ilha de São Vicente o estuário santista (ZÜNDT, 2006). Partindo-se de Santos ou São Vicente até o planalto paulista, o percurso era feito primeiramente em canoas até Cubatão, seguindo-se daí em tropas de mulas por trilhas e caminhos abertos pelos índios. 
Com o desenvolvimento da colônia, foi inaugurada a Calçada do Lorena, provavelmente em 1792 (VARGAS, 1999), com cerca de $50 \mathrm{~km}$ de extensão e menor declividade em relação aos acessos antigos. Desde então, a construção de vias mais rápidas e suaves até o planalto culminou nas ferrovias e rodovias atuais que cortam a planície costeira e a Serra do Mar (MASSAD, 2009), sem esquecer, entretanto, da importância dos trabalhos de acompanhamento geológico-geotécnico, risco geológico e manutenção de obras de arte, túneis e estabilidade de taludes das construções presentes na Serra do Mar.

Figura 6 - Caminhos e trilhas feitas pelos índios entre São Vicente e o planalto.

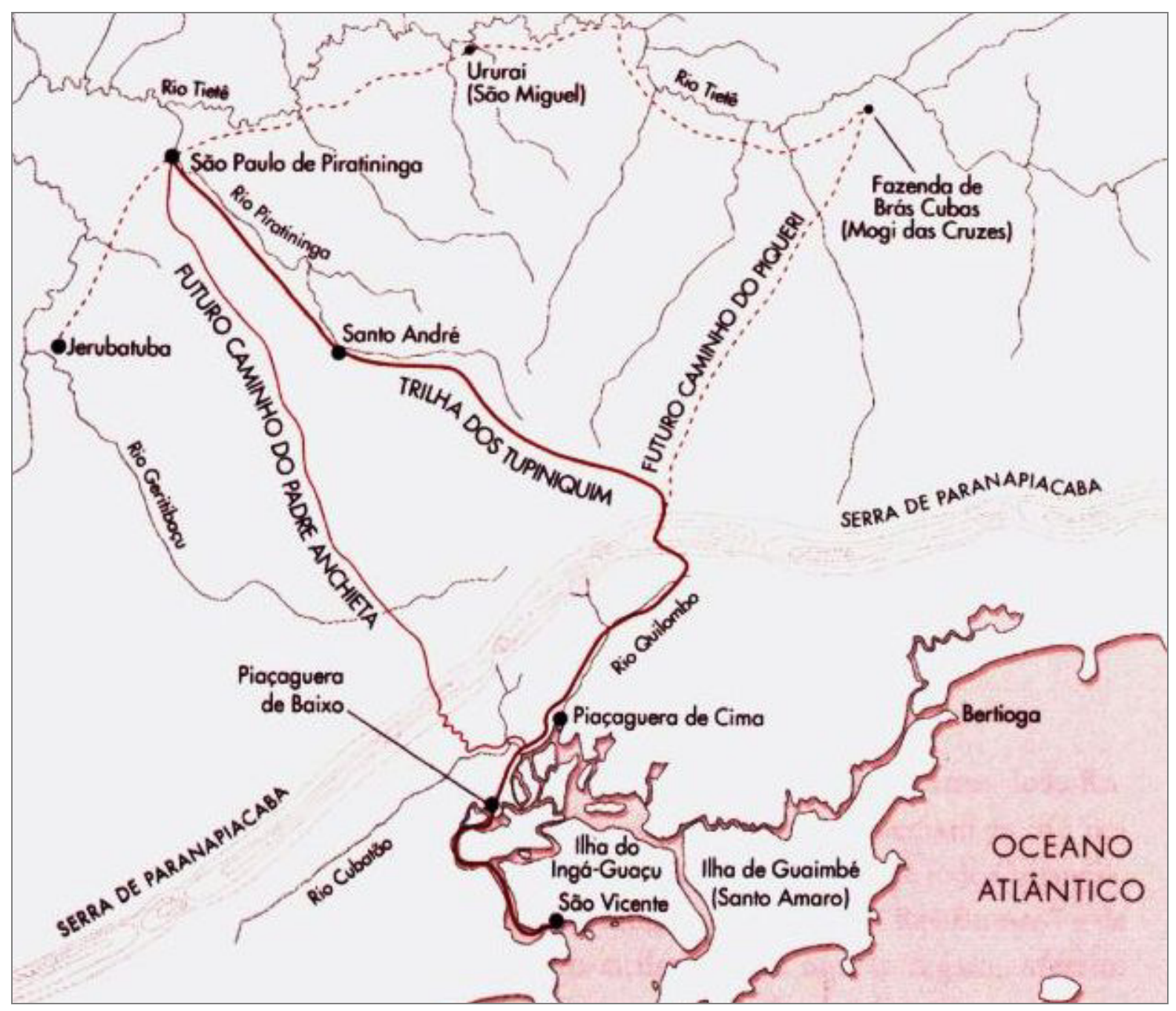

Fonte: Bueno (1999).

\subsubsection{Planície costeira}

A área da RMBS (Figura 7) está inserida em terrenos geológicos distintos quanto à origem e evolução, separados basicamente entre terrenos granítico-metamórficos do 
embasamento que compõem a Serra do Mar, morros e ilhas entre a serra e o mar, e, sedimentos quaternários, que constituem a planície costeira formada pelas variações do nível relativo do mar nos últimos 120000 anos (SUGUIO, 2010).

Figura 7 - Mapa hipsométrico da costa central do Estado de São Paulo e escudo continental adjacente. Em detalhe, a área de estudo e as duas sondagens avaliadas.

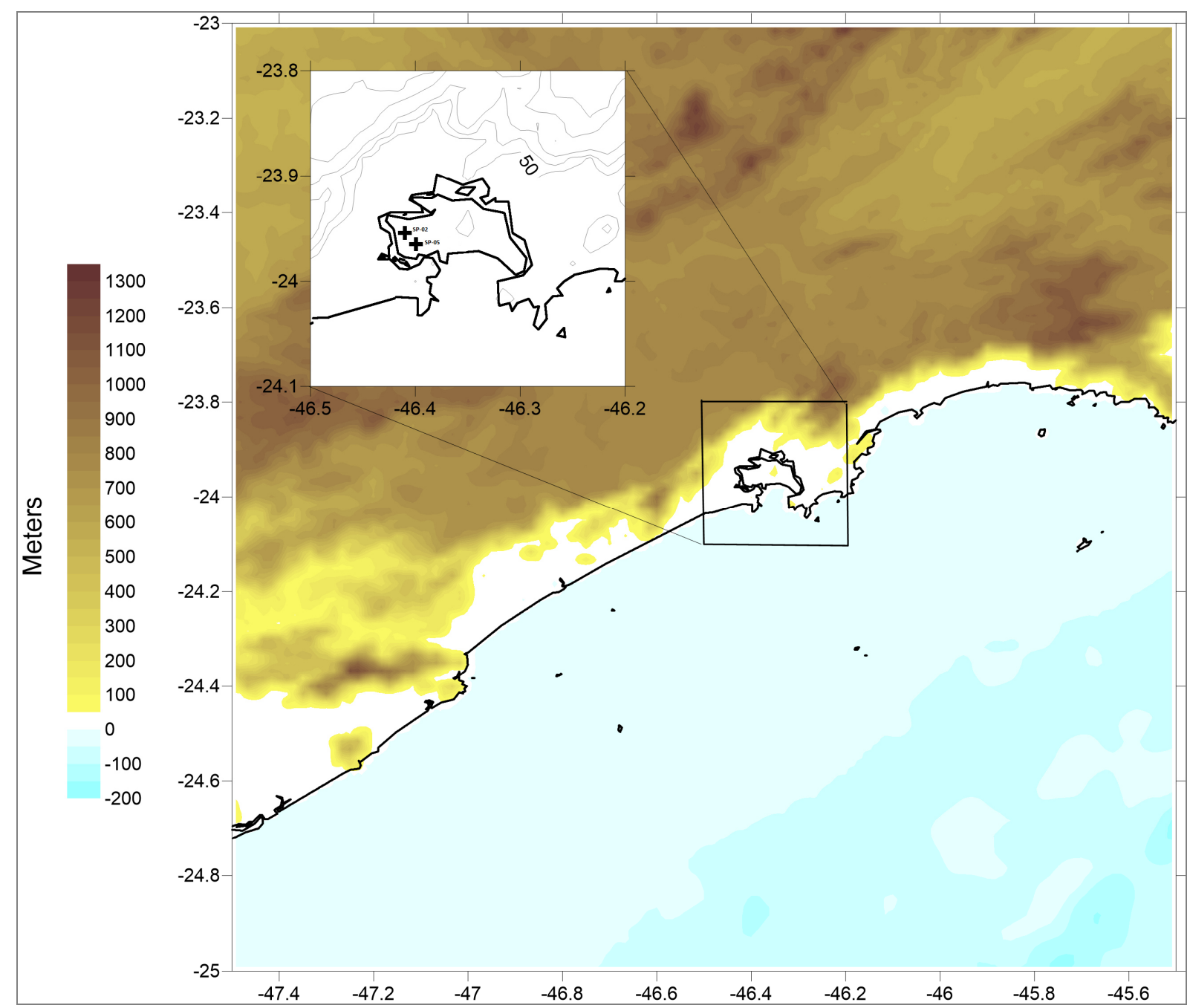

Fonte: Salvaterra et al. (2017) (Dados de: ETOPO1, NOAA 2016).

Segundo Suguio e Martin (1978a, p. 30) “A planície de Santos forma um crescente de $40 \mathrm{~km}$ de extensão por $15 \mathrm{~km}$ de largura máxima, sendo limitada, nas suas extremidades, pela Serra de Mongaguá, ao sul, e pela parte rochosa da Ilha de Santo Amaro ao norte", sendo recoberta por areias e lamas do Pleistoceno Superior e Holoceno, originalmente associadas a dois eventos transgressivos (Cananéia-MIS5e e Santos-Holoceno médio) (SUGUIO; MARTIN, 1978b). No mapa geológico da Baixada Santista de Suguio \& Martin (1978c) os sedimentos da planície são divididos em: i) areias marinhas litorâneas retrabalhadas em 
superfície pelo vento, relacionadas ao Pleistoceno marinho (Formação Cananéia); ii) areias marinhas litorâneas, areias e argilas fluviolagunares e de baías, e areias e argilas de mangue e de pântano, relacionadas ao Holoceno marinho e lagunar, e; iii) areias e argilas continentais, relacionadas ao Quaternário continental indiferenciado. O mapa geológico atualizado da Baixada Santista (CPEA, 2009) é mostrado na Figura 8.

Figura 8 - Mapa geológico da RMBS.

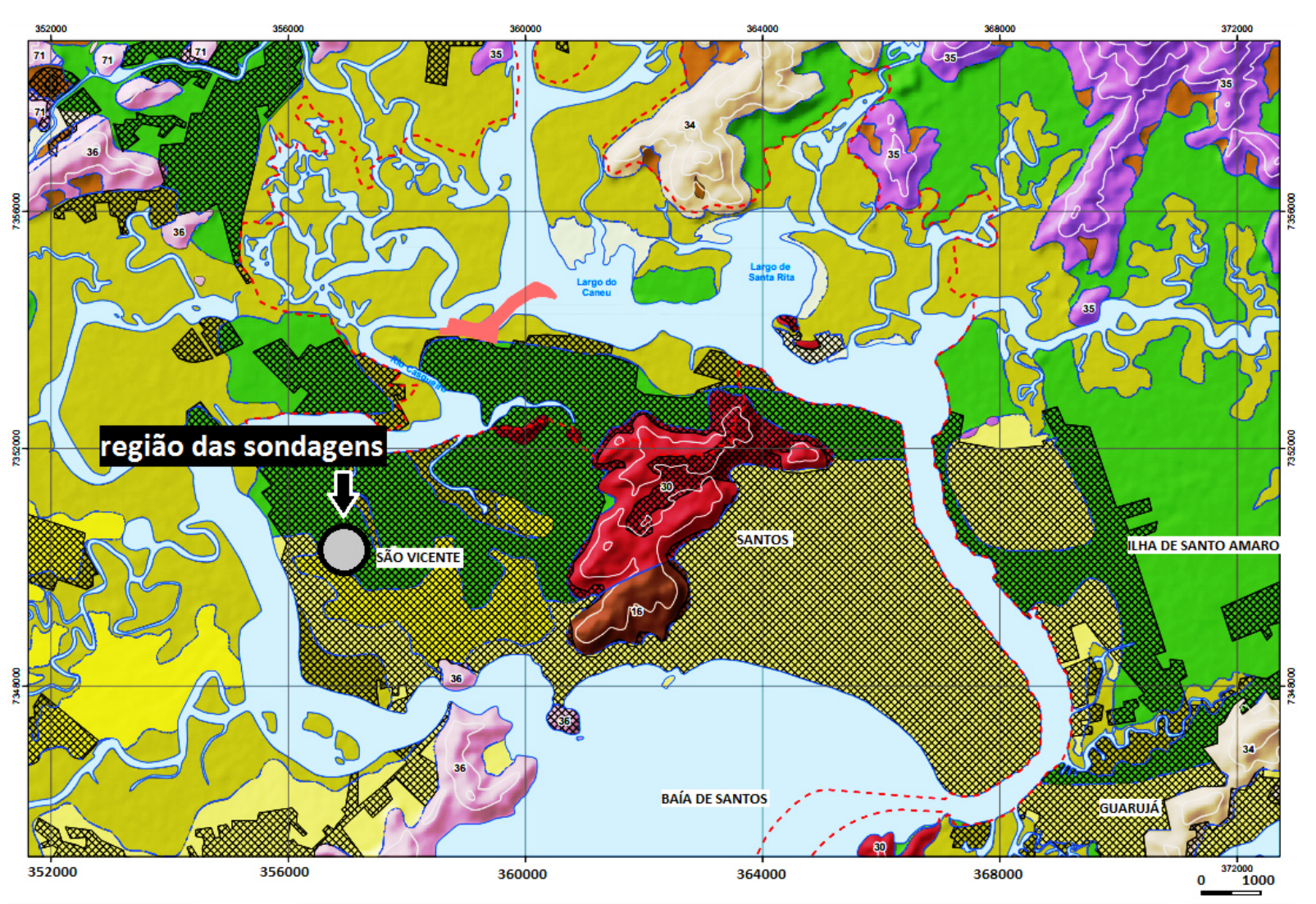

Legenda

Curvas de nivel
Áreas ocupadas
Área diretamente afetada - ADA

Geologia

COBERTURAS SEDIMENTARES QUATERNARIAS Depósitos Continentais

Depósitos Continentais

corpos de tálus e coluviöes (fragmentos rochosos imersos em matriz areno-silto-argilosa) e cones de dejẹcão

sedimentos de baixios (areias finas, siltes $e$ argilas)

sedimentos de mangue e de pântano (areias e argilas

sedimentos fluvio-agunares e de baias (areias e argilas)

areias marinhas litorâneas freqüentemente retrabalhadas em superficie pelo vento

Pleistoceno Marinho (Formação Cananéia)

areias marinhas litorâneas freqüentemente retrabalhadas em superficie pelo vento

DOMINIO COSTEIRO

Rochas Granitóides (Neoproterozóico-Paleozóico)

unsaras (muscovita)-biotita-granito róseo, maciço e eqüigranular (Maciço Granitóide Măe Maria)

uniasate (muscovita)-biotita-granito róseo, maciço e eqüigranular (Maciço Granitóide Santos-ltararé)

22 anfibolio-biotita-granitos a granodioritos equigranulares e com granada (Maciço Granitoide Morrāo)

muscovita-biobitia-granito cinza, inequigranular, por vezes porfirifico (Maciço Granitóide Taiçupeba)

biotita-granito cinza-rosado, porfiritico (Maciços Granitóides Santos e Guarujá)

Complexo Costeiro (Neoproterozóico)

$\frac{35}{35}$ (hornblenda)-biotita-migmatito e/ou granito-gnaisse porfiroclástico

bintita-gnaisses gradando para migmatitos estromatiticos, DOMINIO COSTEIRO DOMiNIO EMBÚ

quarzo-micaxistos e quartzitos, por vezes associados a metabasitos.milonitizados

Fonte: CPEA (2009). 


\subsubsection{Considerações geológico-geotécnicas}

A ocorrência de sedimentos depositados em ambientes costeiros diversos (estuarino, planície de maré, praia e marinho), devido às oscilações marinhas quaternárias, em interação com a complexa trama estrutural continental da Serra do Mar, resultou em depósitos sedimentares com características diferentes (Tabela 1), acarretando por vezes, problemas construtivos como recalques excessivos, rupturas de aterros e necessidade de fundações profundas de alto custo (MASSAD, 2009).

Tabela 1 - Características gerais dos sedimentos na planície sedimentar santista.

\begin{tabular}{|c|c|c|}
\hline & Sedimentos & Características gerais \\
\hline \multirow{4}{*}{  } & Argilas de mangues & $\begin{array}{c}\text { Sedimentadas sobre os SFL. Alternâncias, de forma caótica, de argilas } \\
\text { arenosas e areias argilosas. }\end{array}$ \\
\hline & \multirow{2}{*}{$\begin{array}{l}\text { Argilas de SFL (sedimentos } \\
\text { fluviolagunares) }\end{array}$} & $\begin{array}{l}\text { Deposição em águas calmas de lagunas e de baías. Camadas mais ou } \\
\text { menos homogêneas e uniformes de argilas muito moles a moles } \\
\text { (regiões de calmaria). }\end{array}$ \\
\hline & & $\begin{array}{l}\text { Deposição pelo retrabalhamento dos sedimentos pleistocênicos ou sob a } \\
\text { influência dos rios. Acentuada heterogeneidade, disposição mais ou } \\
\text { menos caótica de argilas muito moles a moles (regiões "conturbadas"). }\end{array}$ \\
\hline & Areias & $\begin{array}{l}\text { Terraços de } 4 \text { a } 5 \text { m acima do nível do mar atual. Não se apresentam } \\
\text { impregnadas por matéria orgânica. Revelam a ação de dunas. }\end{array}$ \\
\hline \multirow{2}{*}{$\begin{array}{l}\stackrel{0}{0} \\
\frac{0}{0} \\
\frac{0}{0} \\
\frac{0}{2}\end{array}$} & Argilas transicionais (ATs) & $\begin{array}{l}\text { Ocorrem a } 20-35 \mathrm{~m} \text { de profundidade, às vezes } 15 \mathrm{~m} \text {, ou até menos. } \\
\text { Argilas médias a rijas, com folhas vegetais carbonizadas (Teixeira, } \\
\text { 1960) e com nódulos de areia quase pura, quando argilosas, ou bolotas } \\
\text { de argilas, quando arenosas (Suguio e Petri, 1973). }\end{array}$ \\
\hline & Areias & $\begin{array}{l}\text { Terraços alçados de } 6 \text { a } 7 \mathrm{~m} \text { acima do nível do mar atual. Amareladas } \\
\text { na superfície e marrom escuras a pretas, em profundidade. }\end{array}$ \\
\hline
\end{tabular}

Fonte: Adaptado de (Massad, 2009).

Os sedimentos lamosos, observados nas sondagens realizadas na Baixada Santista, são descritos genericamente como argilas orgânicas, argilas marinhas, argilas plásticas ou argilas siltosas, não havendo muita coerência no emprego desses termos, sendo então proposta por Massad (2009) a seguinte distinção:

- argilas orgânicas, de aparência turfosa e cor preta ou marrom escura, com pedaços de madeira e detritos vegetais em decomposição;

- argilas marinhas, para sedimentos finos de cor cinza, cinza escura ou preta, por vezes com conchas, e valores de SPT de 0 a 2; 
- argilas plásticas, de cor cinza clara, sem fragmentos de conchas, por vezes com restos vegetais e índices de SPT entre 4 e 6;

- argilas siltosas, mais "quebradiças” que as argilas plásticas.

Um importante aspecto geotécnico dos sedimentos costeiros da Baixada Santista refere-se ao adensamento das argilas de SFL (sedimentos fluviolagunares) pela expulsão da água intersticial (MASSAD, 2009), devido às cargas de grandes construções apoiadas nas areias holocênicas depositadas sobre estas argilas, acarretando recalques e desaprumos consideráveis principalmente nos edifícios mais altos (VARGAS, 1999). 


\section{MATERIAIS E MÉTODOS}

Neste trabalho, foram analisadas e detalhadas duas sondagens geotécnicas com SPT (SP-02 e SP-05) realizadas na RMBS em 2015 pela empresa GEO-PRO, dentro de uma campanha de cinco sondagens na Rodovia SP-160 - Rodovia dos Imigrantes (empresa a qual disponibilizou inicialmente um banco de dados com 192 perfurações executadas ao longo do litoral do Estado de São Paulo).

Optou-se por restringir o estudo e análises laboratoriais nos dois furos citados, pois ambos atendiam os objetivos básicos propostos no trabalho em contribuir com o estudo da evolução quaternária de planícies costeiras com uso de sondagens geotécnicas, devido à localização, profundidades atingidas e intercalações entre areias e lamas observadas nas duas sondagens.

Somente na execução de um perfil geológico apresentado ao fim deste trabalho (Figura $25 \mathrm{~A}$ e B) foram inseridas mais duas sondagens adicionais (SP-03 e SP-04) às duas detalhadas neste estudo (e realizadas na mesma campanha), apresentando uma possível ocorrência mais expressiva de depósitos associados ao MIS3 na região, sem, entretanto, qualquer detalhamento destas duas perfurações adicionais.

Para ambos os furos, manteve-se a numeração estabelecida na obra, adotando-se como referência para as sondagens e amostras a cota altimétrica relativa ao nível do mar atual $(0 \mathrm{~m})$.

Após os trabalhos de campo e descrição macroscópica, as amostras foram remetidas ao laboratório para análises geocronológicas (datação por Radiocarbono), análises sedimentológicas (granulometria) e geoquímicas (teores de Carbonato de Cálcio, Carbono orgânico, Nitrogênio total, razão isotópica $\delta^{13} \mathrm{C}_{\mathrm{PDB}}$ e $\delta^{13} \mathrm{~N}_{\mathrm{AIR}}$, metais).

As sondagens geotécnicas com SPT para a determinação do índice de resistência à penetração $(\mathrm{N})$ e a descrição macroscópica dos materiais amostrados, seguiram as seguintes diretrizes da ABNT e ABGE:

- ABNT NBR 8036:1983: Programação de sondagens de simples reconhecimento dos solos para fundações de edifícios - Procedimento;

- ABNT NBR 6484:2001: Solo - Sondagens de simples reconhecimento com SPT Método de Ensaio;

- ABNT NBR 6502:1995: Rochas e solos - Terminologia;

- ABNT NBR 13441:1995: Rochas e Solos - Simbologia, e; 
- Manual de Sondagens - Associação Brasileira de Geologia de Engenharia e Ambiental (ABGE) - Boletim no 3, 5a edição - São Paulo/2013.

\subsection{Sondagem de simples reconhecimento com SPT}

A locação e identificação das sondagens foram feitas por equipe de topografia seguindo os procedimentos da norma ABNT NBR 8036:1983, de acordo com o projeto da nova pavimentação e acessos da Rodovia dos Imigrantes na região do município de São Vicente/SP.

O diâmetro das perfurações executadas em campo foi de $2^{1 / 2}$ polegadas, atingindo-se a profundidade de 58,45 $\mathrm{m}$ na sondagem SP-02 e 50,45 m na sondagem SP-05.

$\mathrm{O}$ equipamento de sondagem usado consta basicamente de um tripé, uma bomba d'água, um tanque de água de 2001 e ferramentas de corte do solo/sedimento, padronizado conforme a norma ABNT NBR 6484:2001 e Manual de Sondagens da ABGE-2013 (Figura 9).

Figura 9 - Equipamento básico de sondagem de simples reconhecimento com SPT.

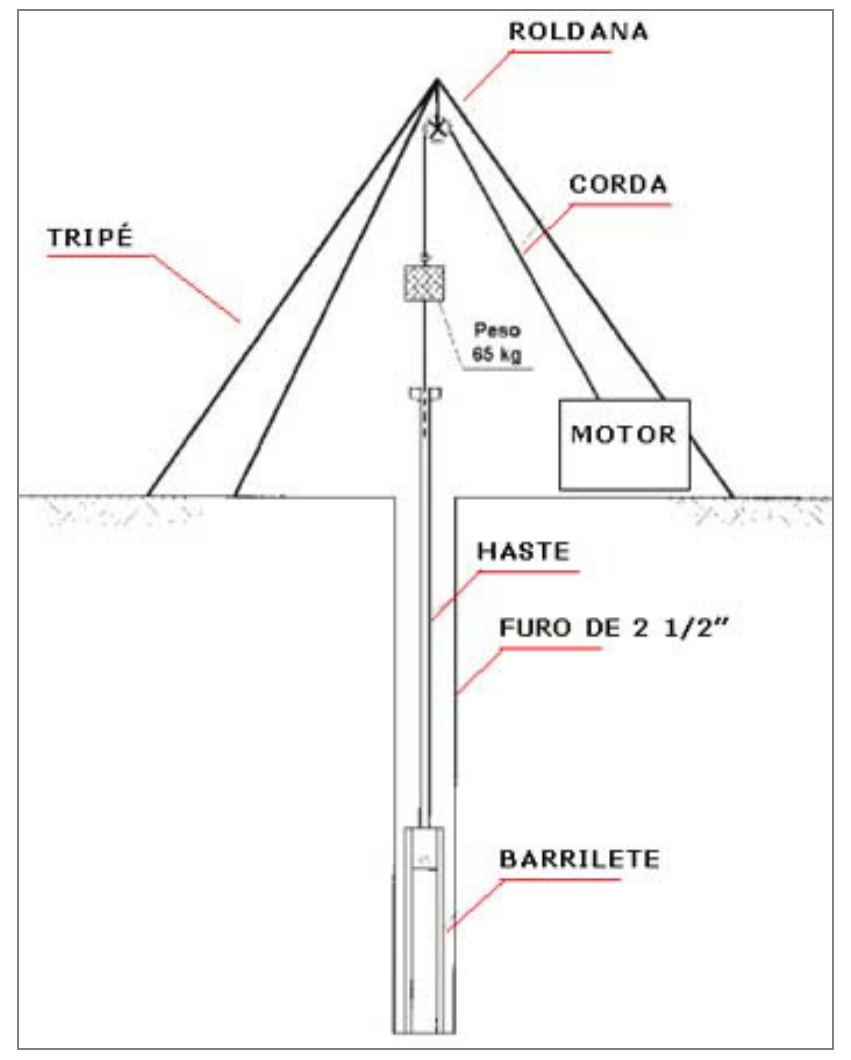

Fonte: Souza; Da Silva; Iyomasa (1998) 
O avanço inicial da sondagem foi feito com trado até atingir o nível freático, seguindo, a partir deste ponto, pelo processo de lavagem com o uso de trépano e circulação de água intercalado (de metro em metro) ao ensaio de penetração dinâmica e amostragem.

O SPT para a medida do índice de resistência à penetração $(\mathrm{N})$ e amostragem, foi feito a cada metro da perfuração, de acordo com a norma ABNT NBR 6484:2001, com a cravação de um barrilete de $45 \mathrm{~cm}$ no fundo do furo a partir do impacto de uma massa metálica de 65 $\mathrm{kg}$ em queda livre de $75 \mathrm{~cm}$ de altura sobre um ressalto da parte superior do hasteamento a ele conectado, anotando-se no boletim de campo a classificação do material amostrado conforme a norma ABNT NBR 6502:1995 e o número correspondente à quantidade de golpes necessária para penetrar o barrilete amostrador no solo/sedimento em um segmento de $45 \mathrm{~cm}$, dividido em três intervalos iguais de $15 \mathrm{~cm}$, considerando-se como valor de SPT o número de golpes correspondente à cravação dos últimos $30 \mathrm{~cm}$ do intervalo ensaiado, descartando-se os $15 \mathrm{~cm}$ iniciais devido à influência da lavagem anterior. As amostras coletadas foram armazenadas em recipientes plásticos herméticos para posterior avaliação macroscópica. Os estados de compacidade e de consistência são apresentados na Tabela 2.

Tabela 2 - Estados de compacidade e de consistência.

\begin{tabular}{|c|c|c|}
\hline Solo & $\begin{array}{c}\text { Índice de resistência à } \\
\text { penetração } \\
\text { N }\end{array}$ & Designação $^{1)}$ \\
\hline \multirow{5}{*}{$\begin{array}{l}\text { Areias e siltes } \\
\text { arenosos }\end{array}$} & $\leq 4$ & Fofa(o) \\
\hline & 5 a 8 & Pouco compacta(o) \\
\hline & 9 a 18 & Medianamente compacta(o) \\
\hline & 19 a 40 & Compacta(o) \\
\hline & $>40$ & Muito compacta(o) \\
\hline \multirow{5}{*}{$\begin{array}{l}\text { Argilas e siltes } \\
\text { argilosos }\end{array}$} & $\leq 2$ & Muito mole \\
\hline & 3 a 5 & Mole \\
\hline & 6 a 10 & Média(o) \\
\hline & 11 a 19 & Rija(o) \\
\hline & $>19$ & Dura(o) \\
\hline \multicolumn{3}{|c|}{$\begin{array}{l}\text { 1) As expressões empregadas para a classificação da compacidade das areias (fofa, compacta, etc.), referem-se } \\
\text { à deformabilidade e resistência destes solos, sob o ponto de vista de fundaçôses, e não devem ser confundida } \\
\text { com as mesmas denominações empregadas para a designação da compacidade relativa das areias ou para } \\
\text { situação perante o índice de vazios críticos, definidos na Mecânica de Solos. }\end{array}$} \\
\hline
\end{tabular}

Fonte: ABNT NBR 6484:2001. 


\subsection{Descrição macroscópica, elaboração dos perfis geológico-geotécnicos individuais e relatório final de sondagens}

Superada a etapa de campo, a planta com a locação das sondagens, os boletins de campo e as amostras coletadas, foram enviadas para avaliação e descrição macroscópica por geólogo, seguindo as orientações da norma ABNT NBR 6502:1995: Rochas e solos e do Manual de Sondagens da ABGE-2013, considerando textura principal e secundária, estrutura, origem e cor dos solos para a classificação e distinção dos diferentes materiais geológicos recebidos.

O produto da descrição macroscópica foi enviado para desenho e confecção dos perfis individuais com uso de software específico de sondagens, onde, para cada ponto perfurado, foi gerado um perfil geológico-geotécnico na escala vertical 1:100 apresentando os dados do contratante, obra, local, número da sondagem, cota e coordenadas, data de início e término da perfuração, profundidade do revestimento, início e término do procedimento de lavagem, índices de resistência à penetração $(\mathrm{N})$, valores de SPT, consistência e/ou compacidade, profundidade e classificação das camadas, interpretação geológica, simbologia, leitura inicial e final do nível d'água, culminando em um relatório composto por perfis geológicogeotécnicos individuais, planta com o posicionamento das sondagens e descrição dos procedimentos, com terminologia e simbologia de acordo com as normas ABNT NBR pertinentes.

\subsection{Sondagens geotécnicas avaliadas}

As duas sondagens geotécnicas avaliadas neste trabalho foram escolhidas devido às profundidades atingidas e intercalações entre areias e lamas ao longo dos furos, observadas na macroscopia, bem como, pela localização e distância entre elas (cerca de $1360 \mathrm{~m}$ ).

A sondagem SP-02 foi feita nas coordenadas UTM 23K 356523,91 m E / 7350128,77 $\mathrm{m} \mathrm{S}$ e cota $8 \mathrm{~m}$, atingindo a profundidade final de $58,45 \mathrm{~m}$ (cota $-50,45 \mathrm{~m}$ ) e totalizando cinquenta e nove amostras, as quais, após a descrição macroscópica, foram enviadas ao laboratório para análises sedimentares (granulometria), geoquímicas (teores de carbonato de cálcio, carbono orgânico, nitrogênio total, metais) e isotópicas $\left(\delta^{13} \mathrm{C}\right)$.

A sondagem SP-05 foi feita nas coordenadas UTM 23K 357351,72 m E / 7349051,79 $\mathrm{m} \mathrm{S}$ e cota $6 \mathrm{~m}$, atingindo a profundidade final de $50,45 \mathrm{~m}$ ( $\operatorname{cota}-44,45 \mathrm{~m})$ e totalizando 
cinquenta e uma amostras, as quais, após a descrição macroscópica, foram enviadas ao laboratório para análise sedimentológica (granulometria).

Conforme já exposto no início deste capítulo, para a confecção de um perfil geológico local (Figuras 26 A e B) adicionaram-se duas sondagens (SP-03 e SP-04) realizadas na mesma campanha da SP-02 e SP-05, sem, entretanto, qualquer detalhamento analítico ou laboratorial de tais furos adicionais, considerando-se somente as descrições macroscópicas de campo destas perfurações, correlacionando-as com as sondagens detalhadas no trabalho baseando-se na ocorrência e intercalação em profundidade entre areias e lamas ao longo de cada furo.

\subsection{Análises geocronológicas}

A datação com uso do radiocarbono ${ }^{14} \mathrm{C}$ foi realizada na fração orgânica das amostras de sedimentos com uso do Acelerador de Espectrometria de Massa (AMS) do Laboratório "Beta Analytic" (Miami, EUA), sendo as idades calibradas calculadas de acordo com a SH13 Calibração do Hemisfério Sul (HOGG et al., 2016).

\subsection{Análises sedimentológicas}

\subsubsection{Granulometria}

Para a análise granulométrica, cerca de $4 \mathrm{~g}$ de sedimento seco por amostra foi lavado com $\mathrm{H}_{2} \mathrm{O}_{2}$ para remoção completa da matéria orgânica, adicionando-se finalmente, $20 \mathrm{~mL}$ de uma solução de $25 \%$ de hexametafosfato de sódio para dispersão dos grãos.

O sedimento preparado foi inserido no analisador por difração laser Malvern Mastersizer 2000 do Laboratório de Sedimentologia do IOUSP, sendo os resultados obtidos em intervalos de $1 / 4 \varphi$.

Os parâmetros estatísticos da granulometria foram obtidos com auxílio da macro Gradistat, desenvolvida para o software MS Excel (BLOTT; PYE, 2001).

A análise fatorial por correspondência foi usada para o reconhecimento das distribuições dos tamanhos de grãos com auxilio do programa Past versão 3.15 (HAMMER et al., 2001), a qual possibilitou correlacionar os resultados da granulometria em um espaço vetorial ordenado segundo aspectos de interesse e relações existentes entre as variáveis. 


\subsection{Análises geoquímicas}

\subsubsection{Conteúdo de Carbonato de Cálcio $\left(\mathrm{CaCO}_{3}\right)$}

$\mathrm{O}$ conteúdo de carbonato de cálcio $\left(\mathrm{CaCO}_{3}\right)$ foi determinado pela diferença de massa

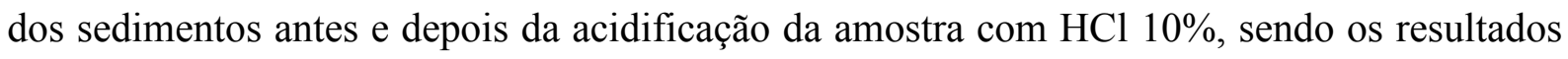
apresentados em $\%$ de $\mathrm{CaCO}_{3}$.

\subsubsection{Conteúdo de Carbono orgânico $\left(C_{\text {org }}\right)$, Nitrogênio total $\left(N_{\text {tot }}\right)$, razão $\delta^{13} C_{P D B} e$ $\delta^{15} \mathbf{N}_{\mathrm{Ar}}$}

$\mathrm{O}$ conteúdo de Carbono Orgânico total $\left(\mathrm{C}_{\mathrm{org}}\right)$, Nitrogênio total $\left(\mathrm{N}_{\text {tot }}\right)$, bem como, a razão isotópica $\delta^{13} \mathrm{C}_{\mathrm{PDB}}$ e $\delta^{15} \mathrm{~N}_{\mathrm{Ar}}$ foram determinados com uso de espectrômetro de massa Finnigan Delta V Plus acoplado ao analisador elementar Costech. O IAEA 600, USGS40, Leco $^{\text {TM }}$ Soil e um padrão secundário de sedimento marinho de Ubatuba/SP (Sudeste do Brasil) foram utilizados como materiais de referência.

Valores de $\delta^{13} \mathrm{C}_{\mathrm{PDB}}$, N/C têm sido usados como indicativos da contribuição de matéria orgânica de origem continental versus marinha (GOVIN et al., 2012).

Os resultados das razões $\delta^{13} \mathrm{C}_{\mathrm{PDB}}$ e $\delta^{15} \mathrm{~N}_{\mathrm{Ar}}$ são apresentados como $\delta^{13} \mathrm{C}_{\mathrm{PDB}}$ e $\delta^{15} \mathrm{~N}_{\mathrm{Ar}}$ (\%), e, têm sido usados para correlações a fases com maior influência marinha ou terrestre, levando-se em conta que em áreas costeiras a identificação da fonte isotópica é dificultada pela matéria orgânica de algas marinhas e plantas $\mathrm{C}_{3}$ e $\mathrm{C}_{4}$ (KLEIN; DE MAHIQUES, 2003).

\subsubsection{Metais}

Os metais (Al, Ba, Ca, Fe, K, Mg, Sc, Sr, Ti, e V) foram analisados em espectrômetro de emissão atômica por plasma acoplado Varian 710 ICP-OES, seguindo os procedimentos de digestão total estabelecidos pelo método 3052 da Agência de Proteção Ambiental dos Estados Unidos. A metodologia para a determinação completa de metais é descrita em De Mahiques et al. (2017).

A razão metal/metal, na forma logarítmica, tem sido usada para auxiliar na interpretação da característica marinha e/ou terrestre, rocha-fonte e clima (RAZIK et al., 2015; DE MAHIQUES et al., 2017; GOVIN et al., 2012). Valores de $\ln (\mathrm{Ti} / \mathrm{Ca})$ (GOVIN et al., 2012) são usados para a avaliação da contribuição marinha versus a terrestre. Já os valores 
de $\ln (\mathrm{Fe} / \mathrm{K})$ (GOVIN et al., 2012) têm sido usados como um proxy no intemperismo de rochas-fonte, enquanto os valores de $\ln (\mathrm{Ti} / \mathrm{Al})$ têm sido usados como proxies de mudanças na energia do ambiente (CHEN et al., 2013; GOVIN et al., 2012). 


\section{RESULTADOS}

Inicialmente, são apresentados os resultados de campo (descrição do material e SPT), análises geocronológicas $\left(\delta^{13} \mathrm{C}\right)$, sedimentológicas (granulometria) e geoquímicas $\left(\mathrm{CaCO}_{3}\right.$, $\mathrm{C}_{\text {org }}, \mathrm{N}_{\text {tot }}, \delta^{13} \mathrm{C}_{\mathrm{PDB}}, \delta^{15} \mathrm{~N}_{\mathrm{AIR}}$, metais) da sondagem SP-02, seguidos dos resultados de campo (descrição do material e SPT) e granulometria da sondagem SP-05.

Com base na macroscopia das sondagens, para os sedimentos estuarinos os intervalos arenosos foram separados dos lamosos e distintos do aterro e do solo de alteração de rocha (observados na sondagem SP-02), separação corroborada pelos resultados da granulometria.

Por não ser foco do presente trabalho, os materiais de aterro e solo de alteração de rocha encontrados na sondagem SP-02 não foram detalhados, mas seus resultados aparecem associados aos resultados da perfuração (perfil e figuras).

A intercalação entre intervalos arenosos e lamosos ao longo das sondagens SP-02 e SP-05 e respectivos valores de $\mathrm{N}_{\mathrm{SPT}}$ de cada perfuração são apresentados na Figura 10.

Figura 10 - Perfis das sondagens geotécnicas SP-02 e SP-05.

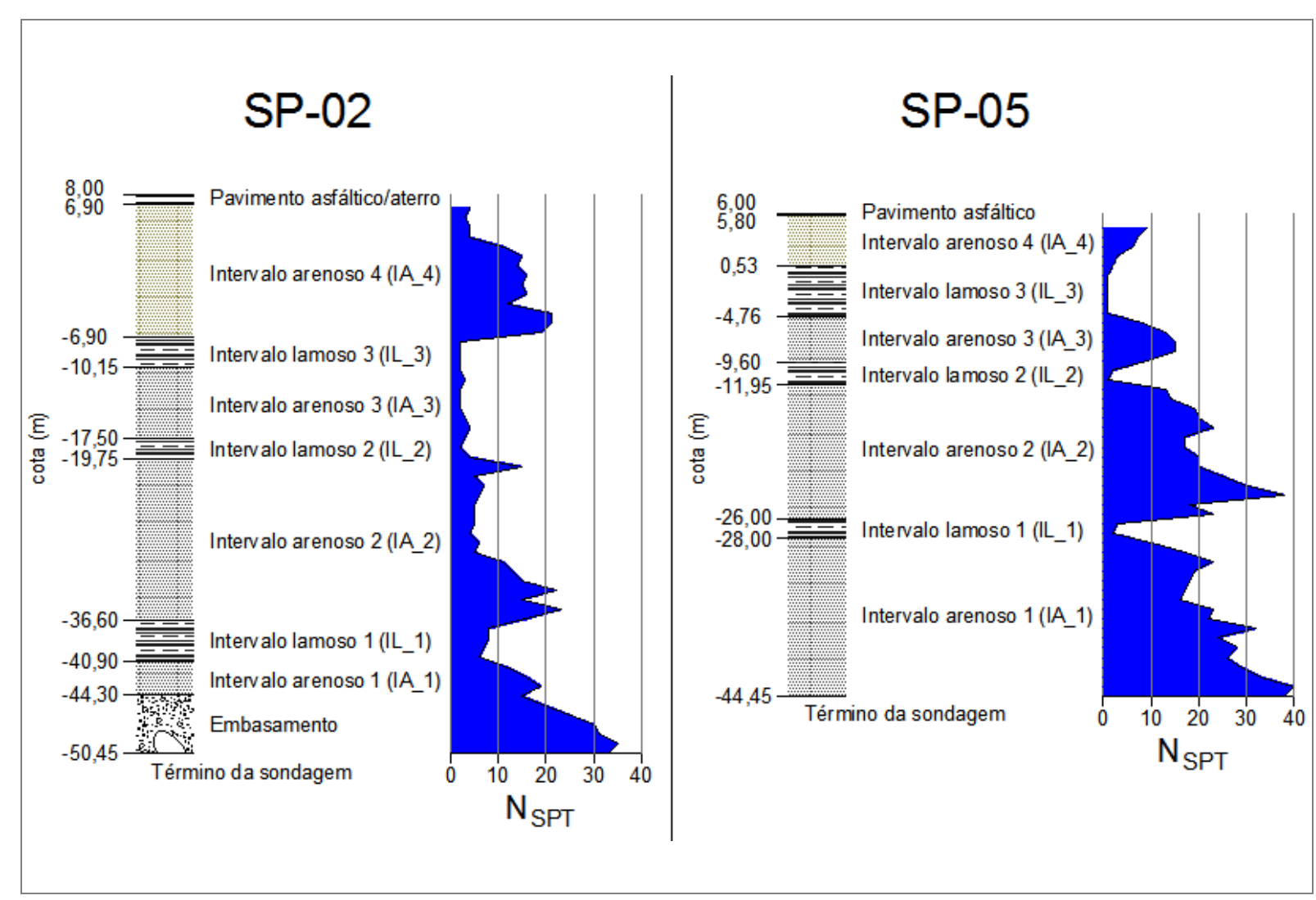

Fonte: Autor. 


\subsection{Sondagem SP-02}

A descrição macroscópica dos materiais amostrados permitiu a identificação de três domínios geológico-geotécnicos distintos, da base para o topo:

- Solo de alteração de rocha (SAR), a partir da cota $-44,3 \mathrm{~m}$ até o final do furo (cota $-50,45 \mathrm{~m}$ ), produto da alteração de rochas do embasamento rochoso;

- Sedimentos estuarinos (SE) entre as cotas $-44,3 \mathrm{~m}$ e $6,9 \mathrm{~m}$, e;

- Pavimento asfáltico / Aterro (AT) entre as cotas 6,9 m e 8,0 m.

Os resultados de granulometria (diâmetro médio dos grãos $\varphi$ ), $\mathrm{N}_{\mathrm{SPT}}$, descrição macroscópica e interpretação geológica da sondagem SP-02 são apresentados na Figura 11.

Figura 11 - (A) Cotas/perfil; (B) Diâmetro médio dos grãos $(\varphi)$; (C) N N SPT $_{\text {; }}(D)$ Descrição da sondagem SP-02.

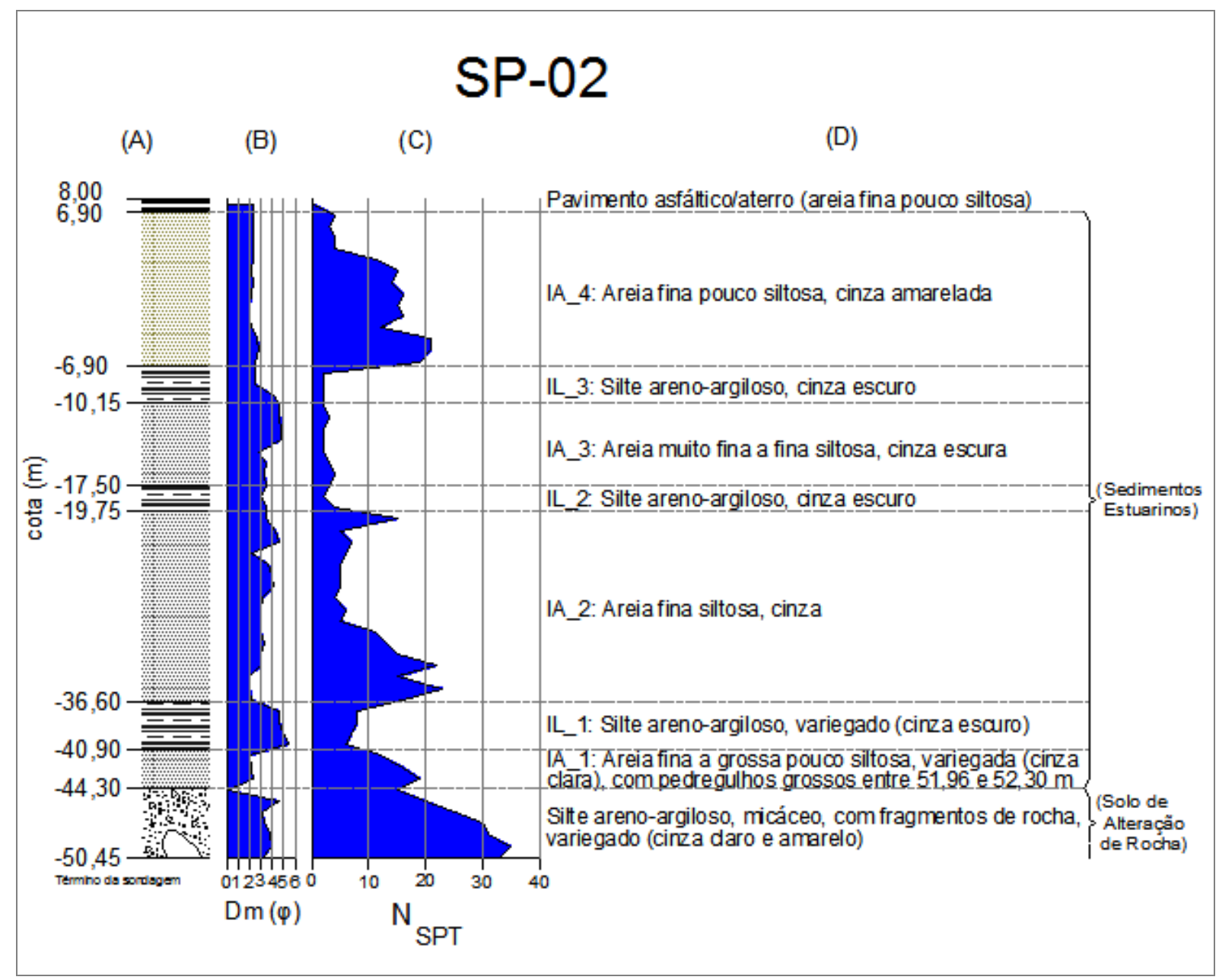

Fonte: Autor. 


\subsubsection{Ensaio SPT}

Os valores de SPT variaram significativamente ao longo da perfuração SP-02 (Tabela 3). De modo geral, os números anotados nas areias foram superiores aos das lamas, com os intervalos arenosos principais apresentando valores de resistência entre 2 e 23 .

Tabela 3 - Valores $\mathrm{N}_{\mathrm{SPT}}$ ao longo da sondagem SP-02.

\begin{tabular}{|c|c|c|c|}
\hline IGEO & AM & Cota (m) & $\mathbf{N}_{\mathrm{SPT}}$ \\
\hline \multirow{2}{*}{$\frac{\mathbb{a}}{a}$} & 0 & 8 & - \\
\hline & 1 & 7 & 4 \\
\hline \multirow{13}{*}{$\begin{array}{l}\mathbb{J}_{1} \\
\leq\end{array}$} & 2 & 6 & 3 \\
\hline & 3 & 5 & 4 \\
\hline & 4 & 4 & 4 \\
\hline & 5 & 3 & 11 \\
\hline & 6 & 2 & 15 \\
\hline & 7 & 1 & 14 \\
\hline & 8 & 0 & 16 \\
\hline & 9 & -1 & 15 \\
\hline & 10 & -2 & 16 \\
\hline & 11 & -3 & 12 \\
\hline & 12 & -4 & 21 \\
\hline & 13 & -5 & 21 \\
\hline & 14 & -6 & 19 \\
\hline \multirow{4}{*}{ "m } & 15 & -7 & 2 \\
\hline & 16 & -8 & 2 \\
\hline & 17 & -9 & 2 \\
\hline & 18 & -10 & 2 \\
\hline \multirow{7}{*}{$\begin{array}{l}m_{1} \\
\mathbb{s}^{\prime}\end{array}$} & 19 & -11 & 3 \\
\hline & 20 & -12 & 2 \\
\hline & 21 & -13 & 2 \\
\hline & 22 & -14 & 2 \\
\hline & 23 & -15 & 3 \\
\hline & 24 & -16 & 4 \\
\hline & 25 & -17 & 3 \\
\hline \multirow{2}{*}{$\begin{array}{l}N_{1} \\
=\end{array}$} & 26 & -18 & 2 \\
\hline & 27 & -19 & 4 \\
\hline
\end{tabular}

\begin{tabular}{|c|c|c|c|}
\hline IGEO & $\overline{A M}$ & Cota (m) & $\overline{N_{S P T}}$ \\
\hline \multirow{17}{*}{$\begin{array}{l}N_{1} \\
\leq\end{array}$} & 28 & -20 & 15 \\
\hline & 29 & -21 & 5 \\
\hline & 30 & -22 & 7 \\
\hline & 31 & -23 & 6 \\
\hline & 32 & -24 & 5 \\
\hline & 33 & -25 & 5 \\
\hline & 34 & -26 & 5 \\
\hline & 35 & -27 & 4 \\
\hline & 36 & -28 & 6 \\
\hline & 37 & -29 & 5 \\
\hline & 38 & -30 & 11 \\
\hline & 39 & -31 & 13 \\
\hline & 40 & -32 & 15 \\
\hline & 41 & -33 & 22 \\
\hline & 42 & -34 & 15 \\
\hline & 43 & -35 & 23 \\
\hline & 44 & -36 & 16 \\
\hline \multirow{4}{*}{ ' } & 45 & -37 & 8 \\
\hline & 46 & -38 & 8 \\
\hline & 47 & -39 & 7 \\
\hline & 48 & -40 & 6 \\
\hline \multirow{4}{*}{$\bar{\sigma}^{\prime}$} & 49 & -41 & 12 \\
\hline & 50 & -42 & 16 \\
\hline & 51 & -43 & 19 \\
\hline & 52 & -44 & 15 \\
\hline \multirow{6}{*}{$\underset{\frac{\alpha}{4}}{c}$} & 53 & -45 & 20 \\
\hline & 54 & -46 & 25 \\
\hline & 55 & -47 & 30 \\
\hline & 56 & -48 & 31 \\
\hline & 57 & -49 & 35 \\
\hline & 58 & -50 & 33 \\
\hline
\end{tabular}

Fonte: Autor.

No IA_1 os valores de SPT ficaram entre 12 e 19, com compacidade compacta e média-compacta, respectivamente, da base para o topo do intervalo. Para o IA_2 os valores de SPT variaram entre 4 e 23 com compacidade compacta, média-compacta, pouco-compacta e fofa variando ao longo do intervalo. No IA_3 os valores de SPT ficaram entre 2 e 4 com compacidade fofa. Para o IA_4 os valores de SPT variaram entre 
3 a 21, com compacidade compacta, média-compacta e fofa, respectivamente, da base para o topo do intervalo.

Nas lamas, os valores de SPT variaram entre 2 e 8 . No IL_1 os valores de SPT foram maiores em relação às lamas do nível intermediário e superior, entre 6 e 8 e consistência média. Para o IL_2 os valores de SPT variaram entre 2 e 4, com consistência muito mole e mole. O IL_3 apresentou valor de SPT igual a 2 em todas as amostras, com consistência muito mole em todo o trecho.

\subsubsection{Análises geocronológicas}

As datações por radiocarbono foram feitas nas amostras lamosas $-40,-19$ e -7, e são apresentadas na Tabela 4.

A amostra -40 (IL_1) apresentou idade limite para o radiocarbono (> 43500) (MIS5e?) e $\delta^{13} \mathrm{C}_{\mathrm{PDB}}$ de -29,6\%o, compatível com matéria orgânica terrestre.

A datação da amostra -19 (IL_2) marcou idade calibrada de 44890 A.P. (2б: 4558044200) (MIS3) e $\delta^{13} \mathrm{C}_{\mathrm{PDB}}$ de -24,4\%, indicativo de material orgânico marinho e terrestre.

Finalmente, a amostra -7 (IL_3) apresentou idade calibrada de 40950 A.P. (2б: 4153040300) (MIS3) e $\delta^{13} \mathrm{C}_{\mathrm{PDB}}$ de -24,5\%o, também indicativo de material orgânico mixohalino.

Tabela 4 - Datação por radiocarbono de amostras lamosas da sondagem SP-02.

\begin{tabular}{|c|c|c|c|c|c|c|c|c|c|}
\hline Beta & Amostra & $\begin{array}{l}\text { Prof. } \\
\text { (m) }\end{array}$ & $\begin{array}{c}\text { (Material): } \\
\text { pre- } \\
\text { tratamento }\end{array}$ & $\delta 13 C_{\text {PDB }}$ & $\begin{array}{l}\text { Idade } \\
\text { conven- } \\
\text { cional }\end{array}$ & $\begin{array}{l}\text { Probabi- } \\
\text { lidade média } \\
\text { e (calibração } \\
2 \text { sigma) }\end{array}$ & $\begin{array}{c}\% \mathrm{C} \\
\text { moderno }\end{array}$ & $\begin{array}{c}\text { Fra- } \\
\text { ção } \\
\text { moder- } \\
\text { na }\end{array}$ & $\Delta 14 C$ \\
\hline 455953 & SP02_15 & -7 & $\begin{array}{l}\text { (sedimento } \\
\text { orgânico): } \\
\text { lavagem } \\
\text { ácida }\end{array}$ & $-24,5$ & $\begin{array}{c}36350 \pm \\
280 \mathrm{AP}\end{array}$ & $\begin{array}{c}\text { cal AP } 40950 \\
(\text { cal AP } \\
41530-40300)\end{array}$ & $\begin{array}{c}1,1 \pm 0,0 \\
\mathrm{pMC}\end{array}$ & $\begin{array}{c}0,0108 \\
\pm \\
0,0004\end{array}$ & $\begin{array}{c}-989,2 \\
\pm \\
0,4 \% \text { o }\end{array}$ \\
\hline 444760 & SP02_27 & -19 & $\begin{array}{l}\text { (sedimento } \\
\text { orgânico): } \\
\text { lavagem } \\
\text { ácida }\end{array}$ & $-24,4$ & $\begin{array}{c}41480 \pm \\
370 \mathrm{AP}\end{array}$ & $\begin{array}{c}\text { cal AP } 44890 \\
\text { (cal AP } \\
45580-44200)\end{array}$ & $\begin{array}{c}0,6 \pm 0,1 \\
\mathrm{pMC}\end{array}$ & $\begin{array}{c}0,0057 \\
\pm \\
0,0003\end{array}$ & $\begin{array}{c}-994,3 \\
\pm \\
0,3 \% \text { o }\end{array}$ \\
\hline 444761 & SP02_48 & -40 & $\begin{array}{l}\text { (sedimento } \\
\text { orgânico): } \\
\text { lavagem } \\
\text { ácida }\end{array}$ & $-29,6$ & $\begin{array}{c}>43500 \\
\text { AP }\end{array}$ & & $\begin{array}{l}<0,4 \\
\mathrm{pMC}\end{array}$ & $\begin{array}{c}< \\
0,0044\end{array}$ & $\begin{array}{c}<- \\
995,6 \\
\% 0\end{array}$ \\
\hline
\end{tabular}

Fonte: Salvaterra et al. (2017). 


\subsubsection{Análises sedimentológicas}

\subsubsection{Granulometria}

Todas as cinquenta e nove amostras da sondagem SP-02 foram analisadas granulometricamente, entretanto, oito não foram detalhadas no trabalho por serem materiais de aterro (amostras 8 e 7) ou de solo de alteração de rocha do embasamento (amostras -45 a 50). O resultado da amostra -44 apresentou $99 \%$ do material com tamanho superior a 500 micra (areia grossa), coincidindo com a descrição macroscópica.

O percentual por classe granulométrica $\varphi$ para cada intervalo é mostrado na Figura 12.

Figura 12 - Percentual por classe granulométrica para cada intervalo da sondagem SP-02.

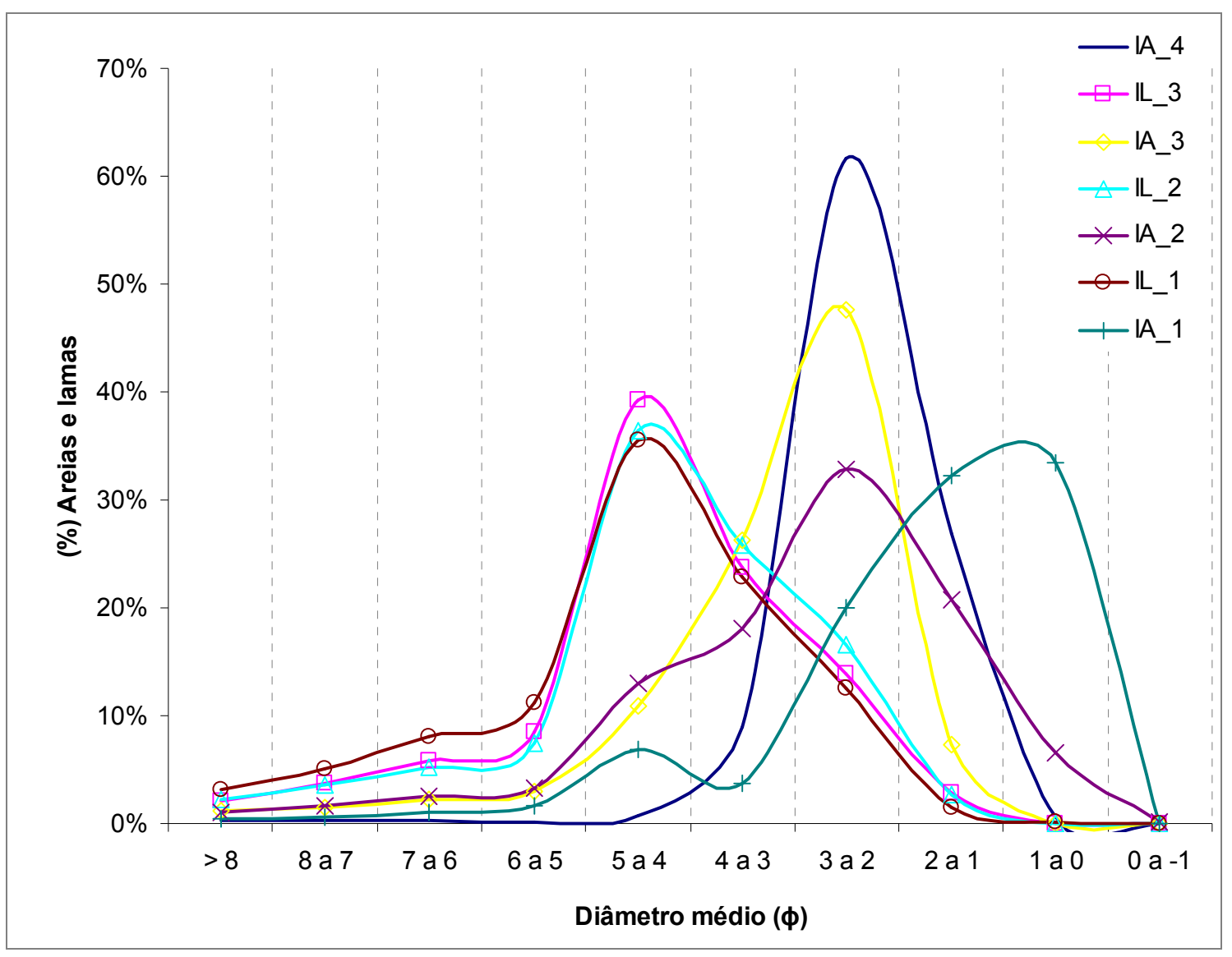

Fonte: Autor.

As areias do IA_1 apresentaram diâmetro médio entre $0,03 \varphi$ e 2,33 $\varphi$, com areia fina predominante no intervalo e areia grossa, presente na amostra -44. Para o IA_2, o diâmetro médio ficou entre $1,93 \varphi$ e 4,06 $\varphi$, com areia fina e areia muito fina na maioria das amostras, 
silte grosso predominante nas amostras -22 e -23 e areia média como fração principal na amostra -34. No IA_3, o diâmetro médio variou entre 2,74 $\varphi$ e 3,47 $\varphi$, com predomínio de areia muito fina no intervalo e areia fina como fração principal nas amostras -11 e -15 . Por fim, o IA_4 apresentou diâmetro médio entre 2,02 $\varphi$ e 2,79 $\varphi$, predominando areia fina. Os histogramas de granulometria dos intervalos arenosos são mostrados na Figura 13.

Figura 13 - Histogramas de granulometria da sondagem SP-02 por intervalo arenoso.

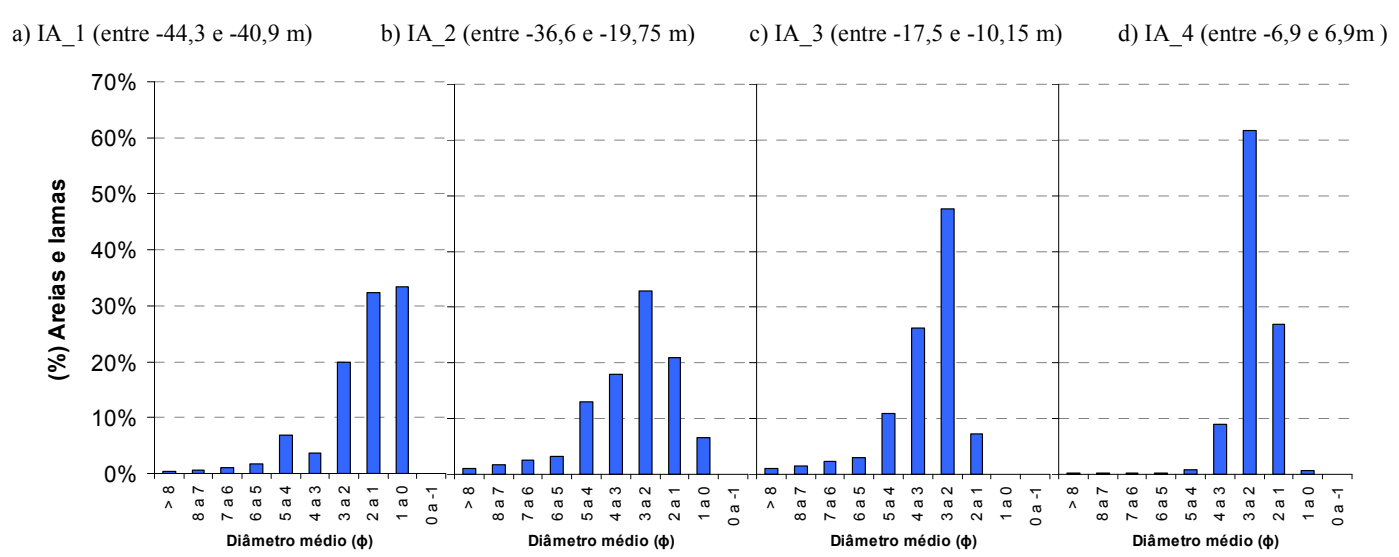

Fonte: Autor.

As lamas do IL_1 apresentaram diâmetro médio entre 4,62 $\varphi$ e 5,39 $\varphi$, com silte grosso predominante no intervalo e silte médio como fração principal na amostra -40. O IL_2 apresentou diâmetro médio entre 4,27 $\varphi$ e 4,63 $\varphi$, com predomínio de silte grosso. Por fim, para o IL_3 o diâmetro médio variou entre 4,13 $\varphi$ e 4,81 $\varphi$, predominado silte grosso. Os histogramas de granulometria dos intervalos lamosos são mostrados na Figura 14.

Figura 14 - Histogramas de granulometria da sondagem SP-02 por intervalo lamoso.

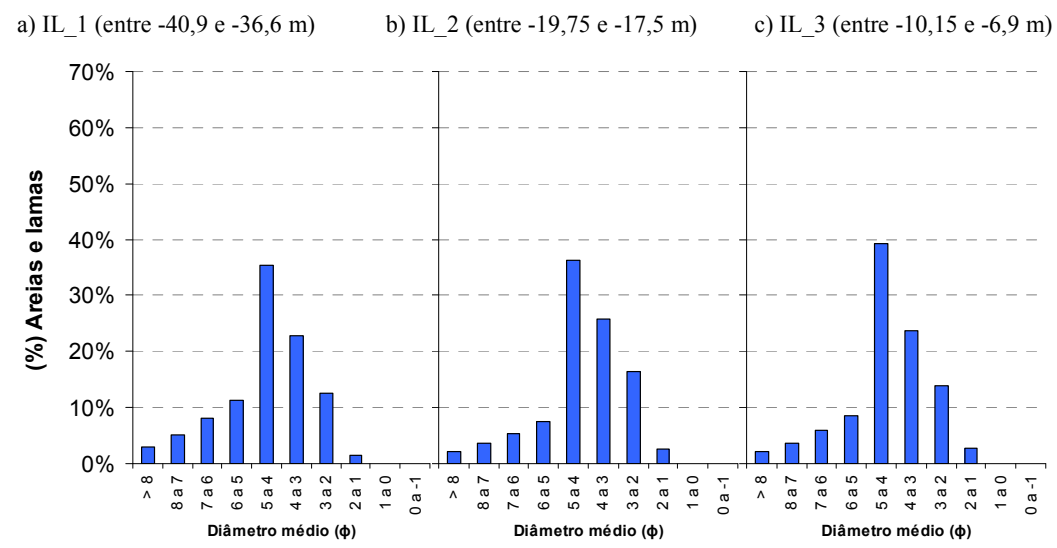

Fonte: Autor. 
A análise fatorial por correspondência permitiu o reconhecimento de quatro tipos principais de distribuições de tamanho de grão $\varphi$ (Figura 15).

O primeiro grupo é representado por um silte grosso a médio mal selecionado e com distribuição platicúrtica positivamente assimétrica, representada pela amostra -40 .

O segundo grupo, expresso pela amostra -34 , consiste em uma distribuição fortemente assimétrica, meso-platicúrtica, com moda principal em 1,75 $\varphi$ e quantidades progressivamente menores de siltes e argila.

O terceiro grupo, representado pela amostra -3 , consiste em uma distribuição bimodal, com moda principal centrada em $3 \varphi$ e distribuição leptocúrtica simétrica. A segunda moda é pouco expressiva e centrada em 5,75 $\varphi$.

Por fim, o quarto grupo é expresso pela amostra 1 e corresponde a uma distribuição simétrica leptocúrtica centrada em $2 \varphi$, associado aos sedimentos do topo da perfuração.

Figura 15 - Variações verticais de fatores 1 (53\% de variância explicada) e 2 (34,2\% de variância explicada) dos dados de granulometria. Distribuições de tamanho de grão são mostradas nos histogramas.

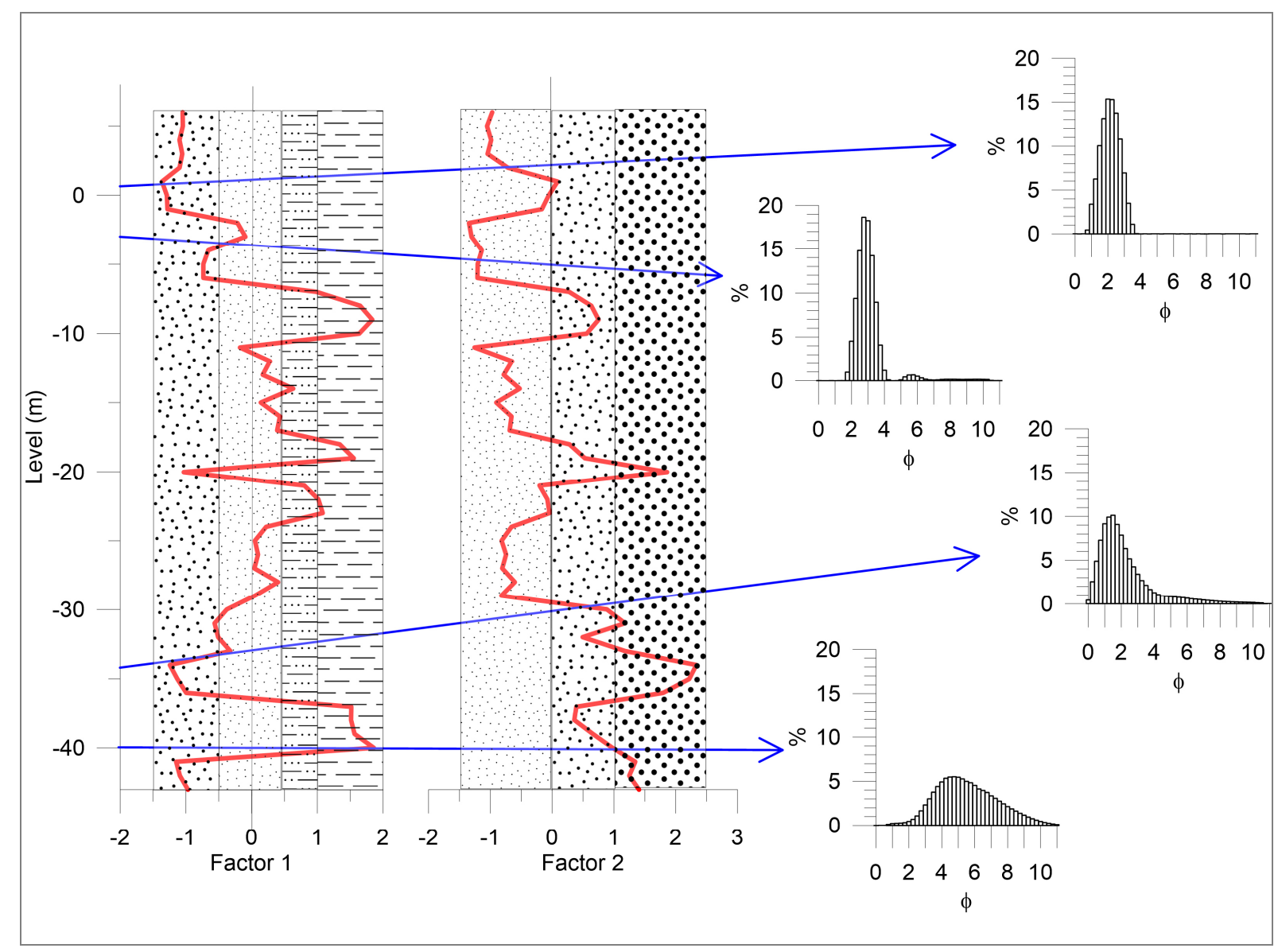

Fonte: Salvaterra et al. (2017). 


\subsubsection{Análises geoquímicas}

\subsubsection{Conteúdo de Carbonato de Cálcio $\left(\mathrm{CaCO}_{3}\right)$}

Os valores de $\mathrm{CaCO}_{3}$ ao longo da sondagem SP-02 são sempre baixos (Figura 16), variando de menos de $0,5 \%$ a cerca de $9,4 \%$, sendo os valores mais destacados encontrados nos intervalos lamosos.

Figura 16 - Conteúdo de $\mathrm{CaCO}_{3}$ ao longo da sondagem SP-02.

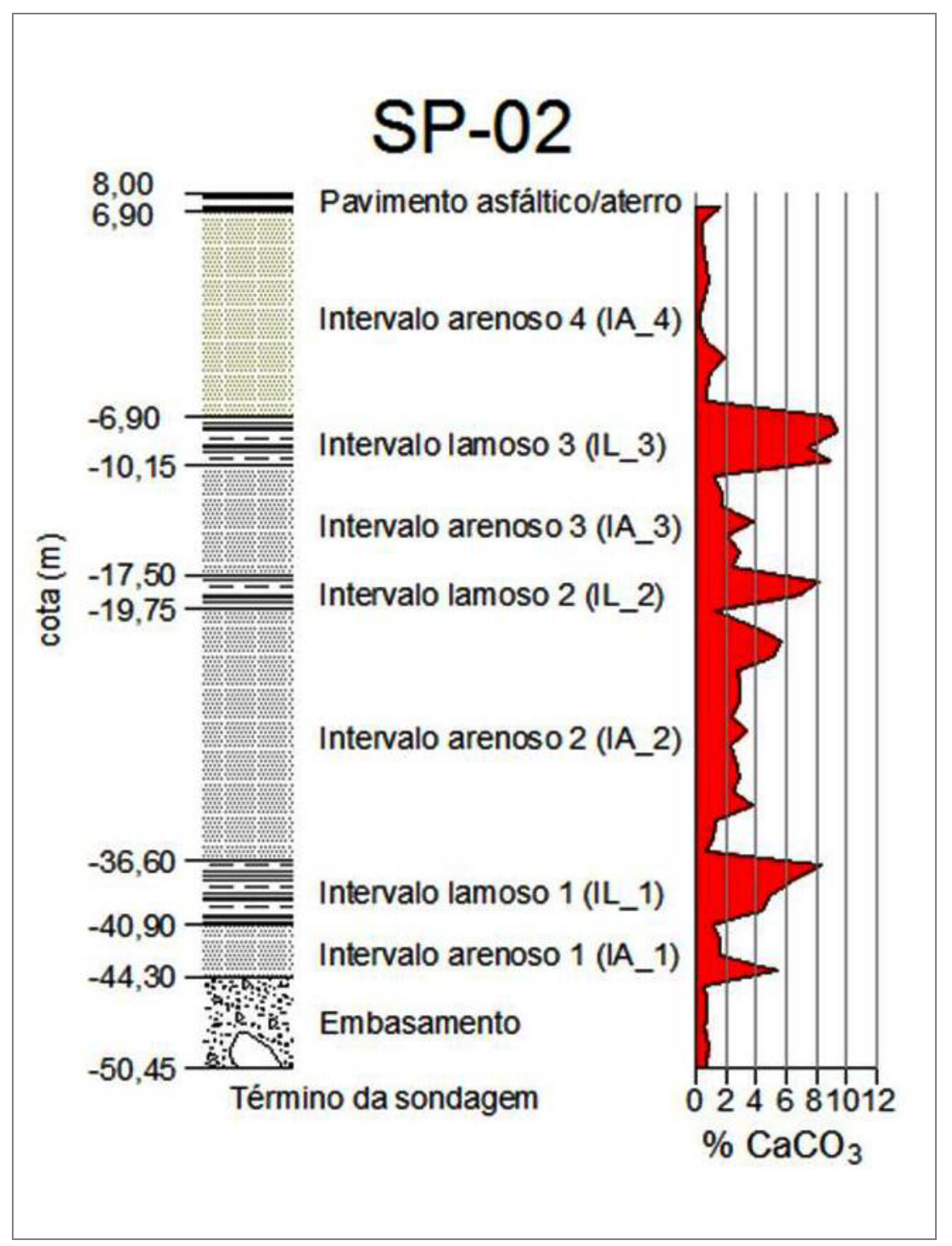

Fonte: Autor. 


\subsubsection{Conteúdo de Carbono orgânico $\left(\mathrm{C}_{\text {org }}\right)$ e Nitrogênio total $\left(\mathbf{N}_{\text {tot }}\right)$}

As concentrações de carbono orgânico variaram entre 0,29\% (-14 m, areia muito fina) e 1,52\% (-40 m, silte médio), com média de 0,69\% nas amostras avaliadas da sondagem SP02 .

A distribuição de carbono orgânico quando comparada com a distribuição dos sedimentos avaliados, apresenta maiores concentrações nos intervalos lamosos (entre $0,57 \% \mathrm{e}$ $1,52 \%$, silte grosso e silte médio, respectivamente) e menores nos intervalos arenosos (entre $0,29 \%$ e $0,31 \%$ areia muito fina).

Segundo Siqueira et al. (2006) nos locais mais abrigados e com menores profundidades ocorre a deposição de sedimentos finos homogêneos, por transporte em suspensão, depositados por processos de floculação e posterior sedimentação, favorecendo a deposição de compostos orgânicos no sistema.

As concentrações de nitrogênio total nas amostras avaliadas da sondagem SP-02 foram baixas, variando entre $0,03 \%$ e $0,07 \%$, com média de $0,03 \%$ para areia fina/muito fina e $0,05 \%$ para silte grosso/médio.

A respeito da proveniência e energia no ambiente de deposição, as amostras -39 e -40 evidenciam um ambiente claramente terrestre. Entretanto, esta condição é alterada na amostra -38 , passando para ambiente mixohalino em todas as amostras analisadas. A amostra -14 mostra uma indicação de ambiente plataformal interno, apresentando valores mais positivos de $\delta^{13} \mathrm{C}$ e N/C (Figura 18 A e B).

\subsubsection{Metais}

Foram feitas análises para os metais $\mathrm{Al}, \mathrm{Ba}, \mathrm{Ca}, \mathrm{Fe}, \mathrm{K}, \mathrm{Mg}, \mathrm{Sc}, \mathrm{Sr}, \mathrm{Ti}, \mathrm{V}, \mathrm{Cr}, \mathrm{Mn}, \mathrm{Cu}$, $\mathrm{Ni}$ e $\mathrm{Zn}$ nas amostras lamosas e de areia muito fina com siltes e argila.

Valores de $\ln (\mathrm{Ti} / \mathrm{Ca}), \ln (\mathrm{Fe} / \mathrm{K}), \ln (\mathrm{Ti} / \mathrm{Al})$ e $\ln ($ razão metais) foram usados como proxies de origem dos sedimentos, intemperismo continental e energia no ambiente de deposição.

A análise da distribuição dos metais revelou a existência de dois grupos principais (Figura 17) de acordo com a mineralogia dominante, sendo o primeiro associado a minerais argilosos englobando $\mathrm{K}, \mathrm{Ba}, \mathrm{Sc}, \mathrm{Al}, \mathrm{Mg}$ e $\mathrm{Sr}$, e o segundo, associado aos óxidos, englobando $\mathrm{Fe}, \mathrm{Ti}, \mathrm{Cr}, \mathrm{V}, \mathrm{Mn}, \mathrm{Cu}, \mathrm{Ni}$ e $\mathrm{Zn}$. O Ca isolado representa material exclusivamente biogênico. 
Com base nesta diferenciação, utilizou-se a seguinte Razão de Metais (RM) (Equação 1):

$$
R M=\frac{\Sigma(K+B a+S c+A l+M g+S r)}{\Sigma(F e+T i+C r+V+M n+C u+N i+Z n)}
$$

Figura 17 - Análise R-mode cluster (Coeficiente de Correlação, UPGMA clustering) de metais analisados neste trabalho.

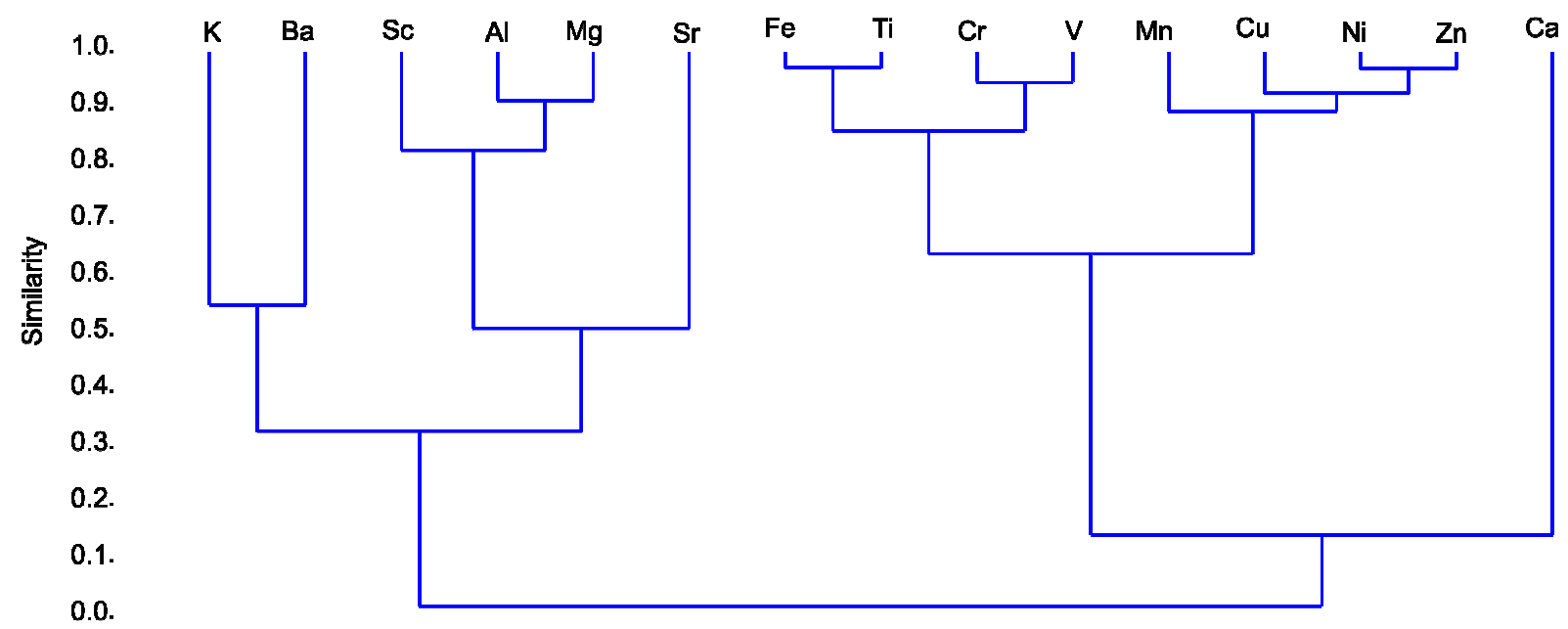

Fonte: Salvaterra et al. (2017).

Os valores de $\ln (\mathrm{Ti} / \mathrm{Ca}$ ) (Figura 18C) foram compatíveis a sedimentos predominantemente de origem continental nas amostras basais (entre $-40 \mathrm{~m} \mathrm{e}-38 \mathrm{~m}$ ) devido à maior proporção de $\mathrm{Ti}$, gradando para sedimentos de origem continental e ambiente mixohalino (-37 m, -17 m, -16 m, -14 m e -7 m) pelo ao aumento na proporção de Ca.

As variações nos valores de $\ln (\mathrm{Fe} / \mathrm{K})$ (Figura 18D) indicam oscilações no aporte de ilita e caulinita no ambiente de deposição e podem ser usados como proxies de intemperismo local e regional (ZIEGLER et al., 2013; NACE et al., 2014; SIMON et al., 2015). Nas amostras avaliadas, elevados valores de $\mathrm{K}$ foram obtidos nas amostras das cotas $-12 \mathrm{~m}$ e -13 m e estão associados às condições mais úmidas na bacia de drenagem (SOUSA, 2017).

Os valores de $\ln (\mathrm{Ti} / \mathrm{Al}$ ) (Figura 18E) são usados como indicadores de variações da energia no ambiente de deposição (SCHMITZ, 1987; CHEN et al., 2013), e de maneira geral nas amostras avaliadas (com exceção de algumas amostras basais), a maioria dos sedimentos indicou deposição em ambiente de baixa energia.

A distribuição da razão de metais ao longo da sequência sedimentar apresenta um padrão distinto quando se compara as duas sequências lamosas (Figura 18F). A sequência 
basal é rica em metais associados a óxidos, como $\mathrm{Fe}$ e Ti, enquanto a sequência lamosa intermediária apresenta elementos característicos de minerais argilosos (silicatos), com Al, $\mathrm{K}$ e Sc. Sedimentos associados a óxidos correspondem à fácies terrestre, enquanto sedimentos silicáticos estariam associados a ambiente mixohalino.

Figura 18 - Variações em $(\mathrm{A}) \delta^{13} \mathrm{C}$; (B) razão N/C; (C) $\ln (\mathrm{Ti} / \mathrm{Ca}) ;(\mathrm{D}) \ln (\mathrm{Fe} / \mathrm{K})$; (E) $\ln (\mathrm{Ti} / \mathrm{Al}) ;(\mathrm{F}) \ln ($ razão metais) ao longo da sondagem SP-02.

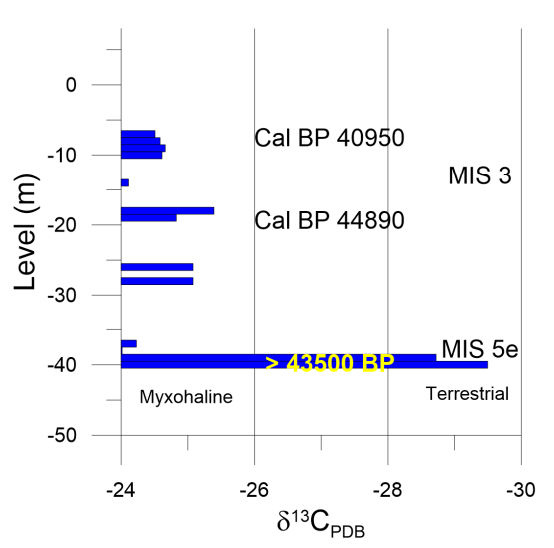

A

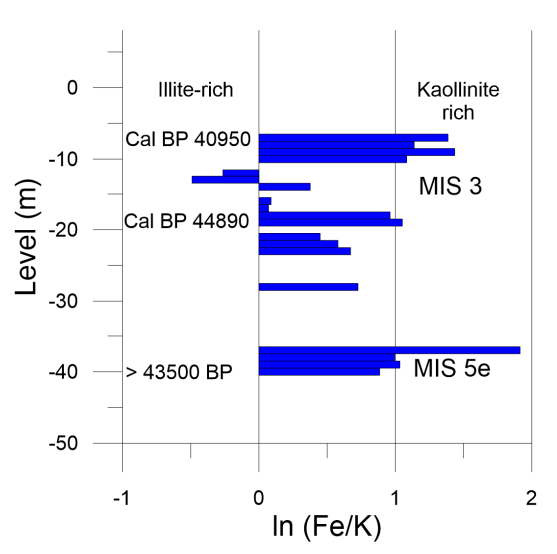

D

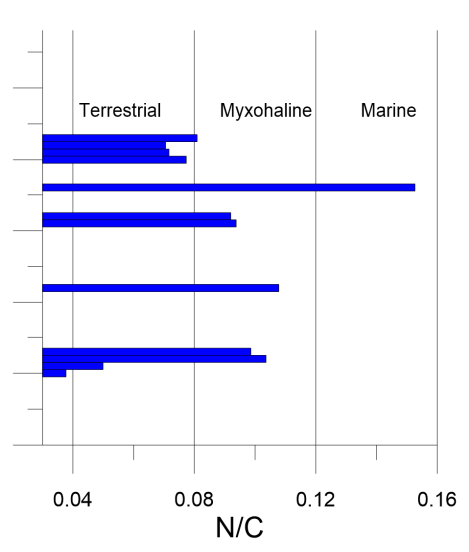

B

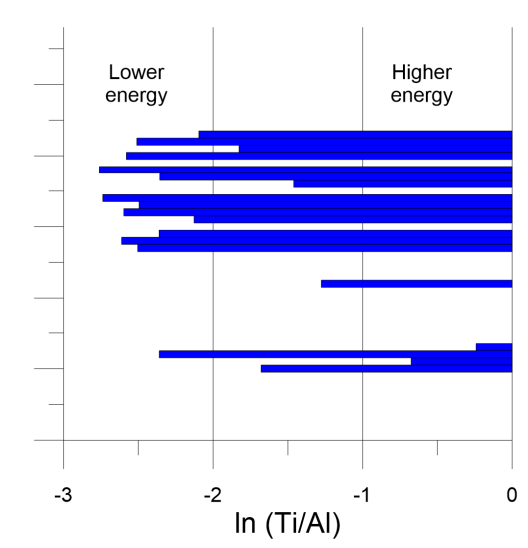

$\mathrm{E}$

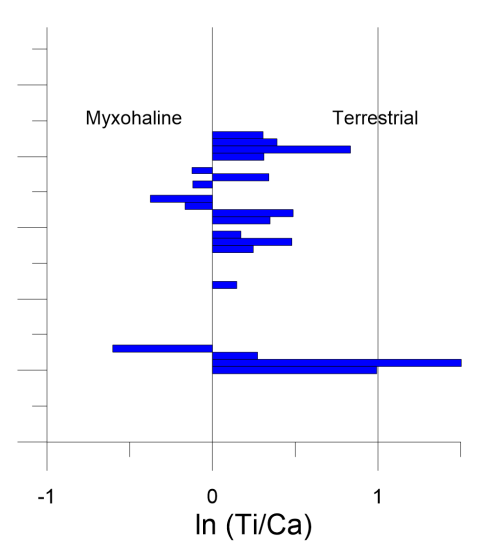

C

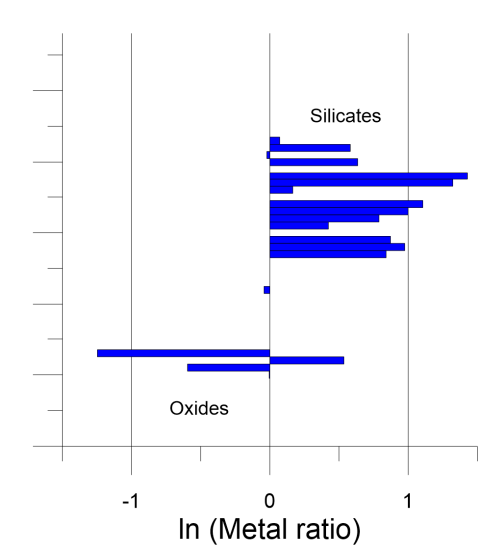

$\mathrm{F}$

Fonte: Salvaterra et al. (2017).

\subsection{Sondagem SP-05}

A descrição macroscópica dos materiais amostrados permitiu a identificação de dois domínios geológico-geotécnicos distintos, da base para o topo:

- Sedimentos estuarinos (SE) entre as cotas $-44,45 \mathrm{~m}$ e $5,8 \mathrm{~m}$;

- Pavimento asfáltico e brita entre as cotas $5,8 \mathrm{~m}$ e $6 \mathrm{~m}$. 
Os resultados de granulometria (diâmetro médio dos grãos $\varphi$ ), $\mathrm{N}_{\mathrm{SPT}}$, descrição macroscópica e interpretação geológica da sondagem SP-05 são apresentados na Figura 19.

Figura 19 - (A) Cotas/perfil; (B) Diâmetro médio dos grãos (ழ); (C) $\mathrm{N}_{\mathrm{SPT}}$; (D) Descrição da sondagem SP-05.

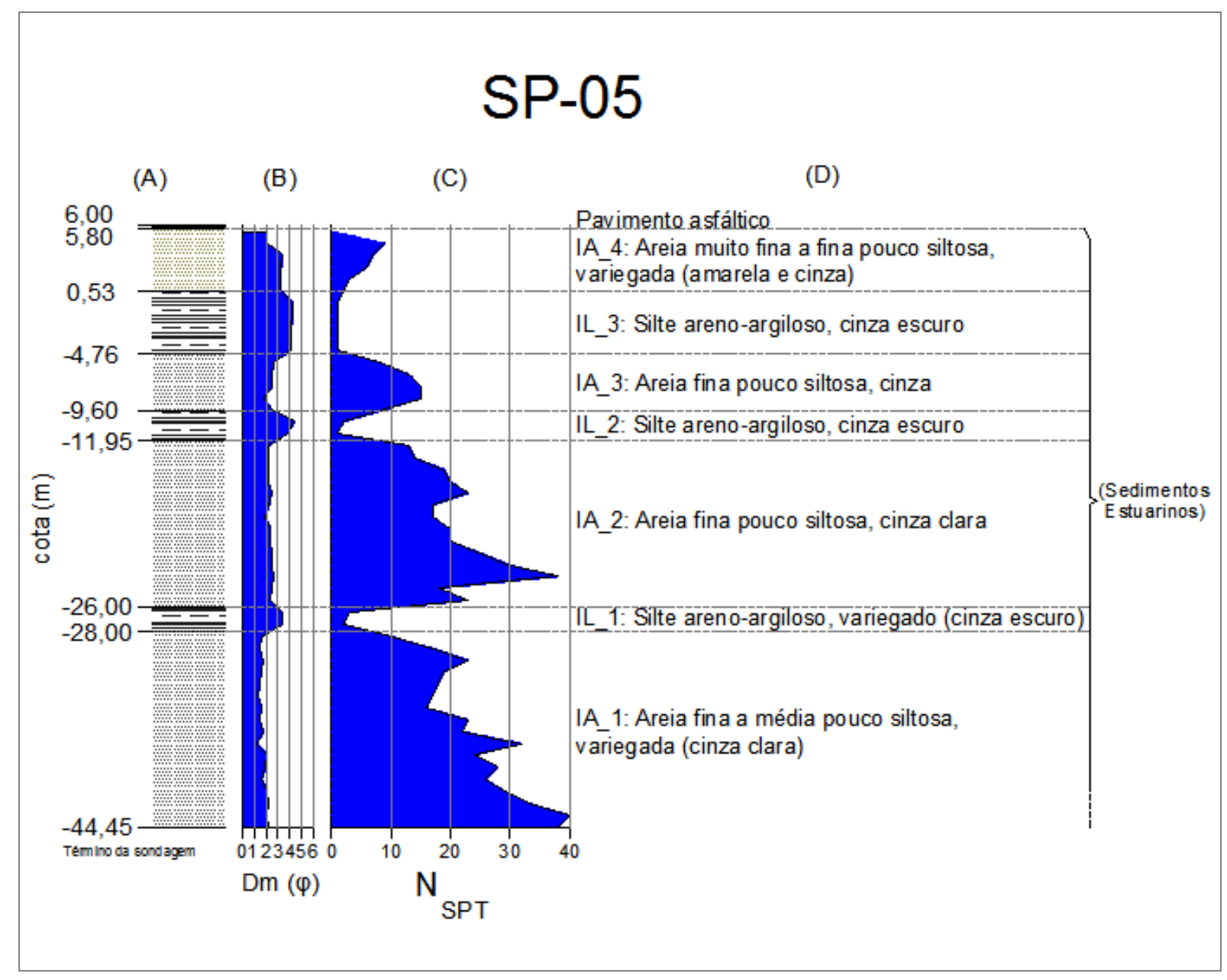

Fonte: Autor.

\subsubsection{Ensaio SPT}

Os valores de SPT para as areias foram superiores aos das lamas, com os intervalos arenosos principais apresentando números entre 2 e 40, sendo mais elevados nas porções internas e/ou basais de cada intervalo (6 a 40) e diminuindo nas transições e contatos com os intervalos lamosos (2 a 13).

$\mathrm{Na}$ tabela 5 são apresentados os valores $\mathrm{N}_{\mathrm{SPT}}$, respectivas cotas e amostras coletadas ao longo da sondagem SP-05. 
Tabela 5 - Valores $\mathrm{N}_{\mathrm{SPT}}$ ao longo da sondagem SP-05.

\begin{tabular}{|c|c|c|c|}
\hline IGEO & AM & Cota $(\mathrm{m})$ & $\mathbf{N}_{\text {SPT }}$ \\
\hline \multirow{6}{*}{$\begin{array}{l}\nabla_{1} \\
\mathbb{S}\end{array}$} & 0 & 6 & - \\
\hline & 1 & 5 & 9 \\
\hline & 2 & 4 & 7 \\
\hline & 3 & 3 & 6 \\
\hline & 4 & 2 & 3 \\
\hline & 5 & 1 & 2 \\
\hline \multirow{5}{*}{$\begin{array}{l}m_{1} \\
=\end{array}$} & 6 & 0 & 1 \\
\hline & 7 & -1 & 1 \\
\hline & 8 & -2 & 1 \\
\hline & 9 & -3 & 1 \\
\hline & 10 & -4 & 1 \\
\hline \multirow{5}{*}{$\begin{array}{l}m \\
\mathbb{I}\end{array}$} & 11 & -5 & 8 \\
\hline & 12 & -6 & 13 \\
\hline & 13 & -7 & 15 \\
\hline & 14 & -8 & 15 \\
\hline & 15 & -9 & 9 \\
\hline \multirow{2}{*}{$\begin{array}{l}N_{1} \\
{ }^{\prime}\end{array}$} & 16 & -10 & 2 \\
\hline & 17 & -11 & 1 \\
\hline \multirow{14}{*}{$\begin{array}{l}N_{1} \\
\leq\end{array}$} & 18 & -12 & 12 \\
\hline & 19 & -13 & 14 \\
\hline & 20 & -14 & 19 \\
\hline & 21 & -15 & 20 \\
\hline & 22 & -16 & 23 \\
\hline & 23 & -17 & 17 \\
\hline & 24 & -18 & 17 \\
\hline & 25 & -19 & 20 \\
\hline & 26 & -20 & 20 \\
\hline & 27 & -21 & 25 \\
\hline & 28 & -22 & 30 \\
\hline & 29 & -23 & 38 \\
\hline & 30 & -24 & 18 \\
\hline & 31 & -25 & 23 \\
\hline
\end{tabular}

\begin{tabular}{|c|c|c|c|}
\hline IGEO & AM & Cota $(\mathrm{m})$ & $\mathbf{N}_{\text {SPT }}$ \\
\hline \multirow{2}{*}{ 'ـ } & 32 & -26 & 3 \\
\hline & 33 & -27 & 2 \\
\hline \multirow{17}{*}{$\overleftarrow{s}^{\prime}$} & 34 & -28 & 10 \\
\hline & 35 & -29 & 17 \\
\hline & 36 & -30 & 23 \\
\hline & 37 & -31 & 19 \\
\hline & 38 & -32 & 18 \\
\hline & 39 & -33 & 17 \\
\hline & 40 & -34 & 16 \\
\hline & 41 & -35 & 23 \\
\hline & 42 & -36 & 22 \\
\hline & 43 & -37 & 32 \\
\hline & 44 & -38 & 24 \\
\hline & 45 & -39 & 28 \\
\hline & 46 & -40 & 26 \\
\hline & 47 & -41 & 29 \\
\hline & 48 & -42 & 33 \\
\hline & 49 & -43 & 40 \\
\hline & 50 & -44 & 38 \\
\hline
\end{tabular}

Fonte: Autor.

No IA_1 os valores de SPT ficaram entre 10 e 40, com compacidade compacta e média-compacta, respectivamente, da base para o topo do intervalo. Para o IA_2 os valores variaram entre 12 e 38 com compacidade compacta e média-compacta intercaladas ao longo do intervalo. No IA_3 os valores de SPT ficaram entre 8 e 15 com compacidade média- 
compacta e pouco compacta, da base para o topo do intervalo. Para o IA_4 os valores de SPT variaram entre 2 e 9, com compacidade fofa, pouco compacta e média-compacta.

Nas lamas os valores de SPT variaram entre 1 e 3 em todos os intervalos lamosos (IL_1, IL_2 e IL_3).

\subsubsection{Análises sedimentológicas}

\subsubsection{Granulometria}

Os resultados de diâmetro médio dos grãos $\varphi$ das cinquenta e uma amostras de sedimentos da sondagem SP-05 confirmaram a variação em profundidade descrita na macroscopia entre areias e lamas, e, assim como na sondagem SP-02, apresentaram correlação com os valores de SPT, medindo-se os menores índices de penetração nas lamas.

O percentual por classe granulométrica $\varphi$ para cada intervalo é mostrado na Figura 20.

Figura 20 - Percentual por classe granulométrica para cada intervalo da sondagem SP-05.

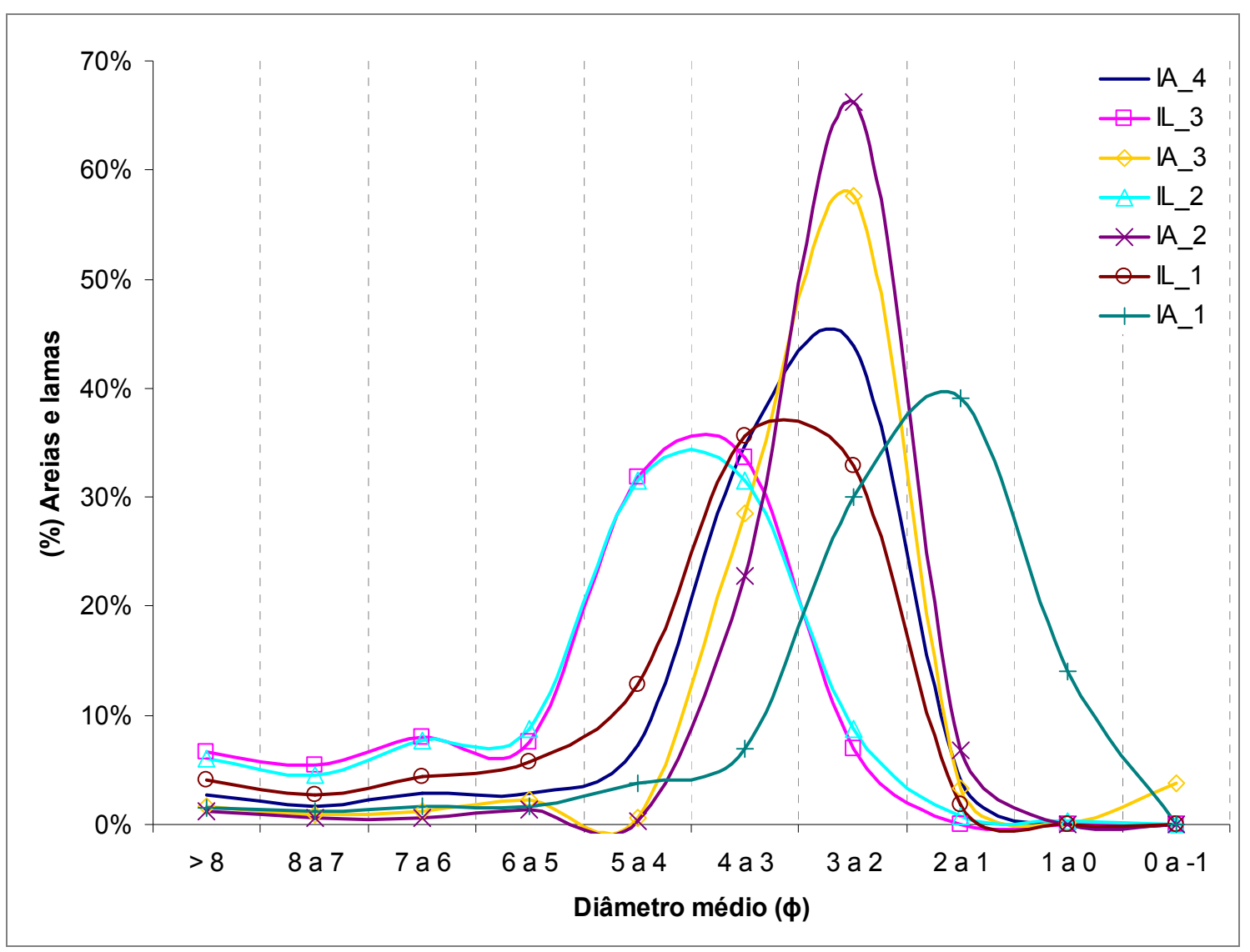

Fonte: Autor. 
As areias do IA_1 apresentaram diâmetro médio entre 1,26 $\varphi$ e 2,23 $\varphi$, com predomínio de areia média, fina e grossa respectivamente, ocorrência de areia fina e um pouco de lamas. Para o IA_2 é encontrado diâmetro médio entre 1,96 $\varphi$ e 2,65 $\varphi$, com areia fina e areia muito fina predominando no intervalo, pequena ocorrência de areia média e ínfima presença de lamas. No IA_3 o diâmetro médio variou entre 1,80 $\varphi$ e 2,60 $\varphi$, com areia fina e areia muito fina predominando no intervalo, pequena ocorrência de areia média e areia muito grossa, com ínfima presença de lamas. Por fim, o IA_4 apresentou diâmetro médio entre 2,09 $\varphi$ e 3,33 $\varphi$, com areia fina e areia muito fina predominando no intervalo, ocorrência de areia média e aumento na presença de lamas em relação aos outros intervalos arenosos. $\mathrm{O}$ percentual por classe granulométrica $\varphi$ para cada intervalo arenoso é mostrado na Figura 21.

Figura 21 - Histogramas da granulometria da sondagem SP-05 por intervalo arenoso.

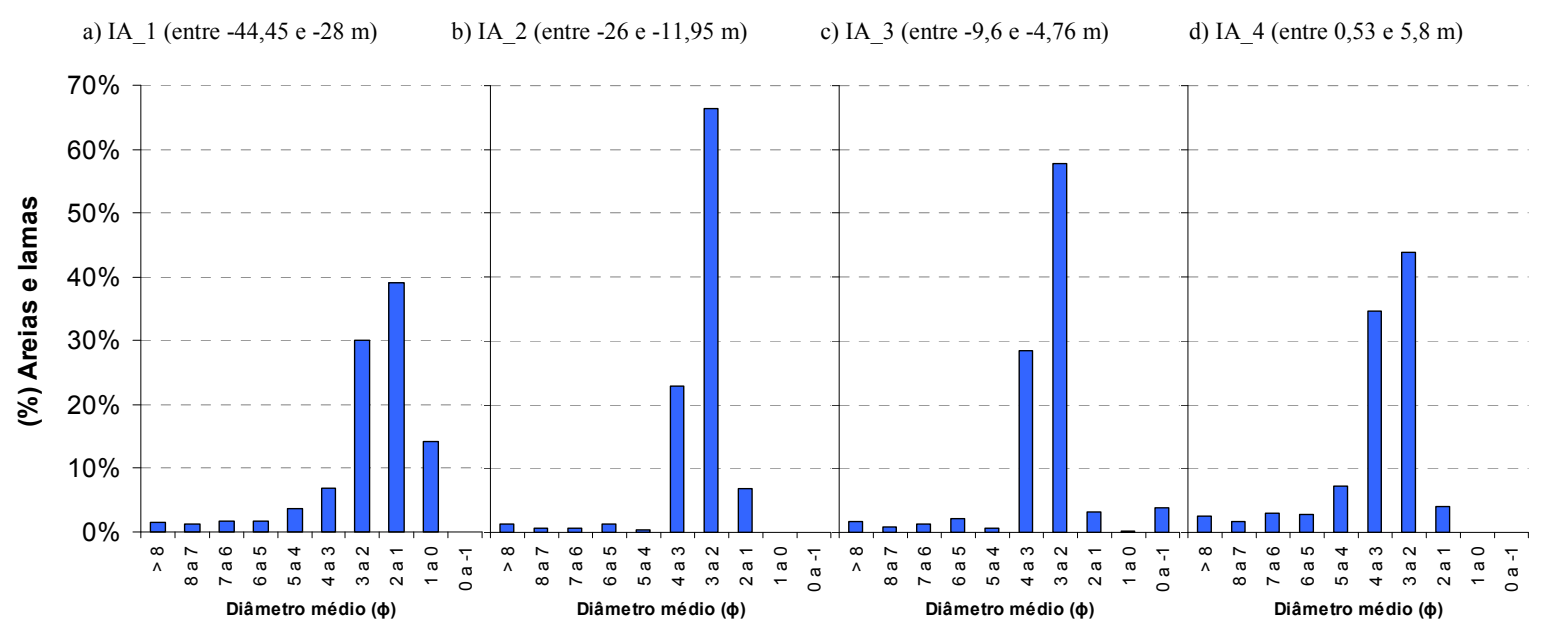

Fonte: Autor.

Para as ocorrências de lamas e areias lamosas, o IL_1 apresentou diâmetro médio de 3,32 $\varphi$ e predomínio de areia muito fina e areia fina, com importante presença de lamas (cerca de $30 \%$ ) e destaque da ocorrência de silte grosso $(\sim 13 \%)$, e, ainda que composto em sua maioria por areias, este intervalo foi considerado como lamoso devido à quantidade expressiva de lamas e respectivo comportamento geotécnico (semelhante ao de intervalos lamosos). O IL_2 apresentou diâmetro médio entre 3,76 $\varphi$ e 4,42 $\varphi$, com predomínio de silte grosso e areia muito fina e ocorrência de areia fina e lamas. Por fim, para o IL_3 o diâmetro médio variou entre 4,11 $\varphi$ e 4,27 $\varphi$, com predomínio de silte grosso e areia muito fina e ocorrência de areia fina e lamas. O percentual por classe granulométrica $\varphi$ para cada intervalo lamoso é mostrado na Figura 22. 
Figura 22 - Histogramas da granulometria da sondagem SP-05 por intervalo lamoso.

a) IL_1 (entre -28 e - -26 m)

b) IL 2 (entre - 11,95 e - $-9,6$ m)

c) IL_3 (entre $-4,76$ e $0,53 \mathrm{~m}$ )

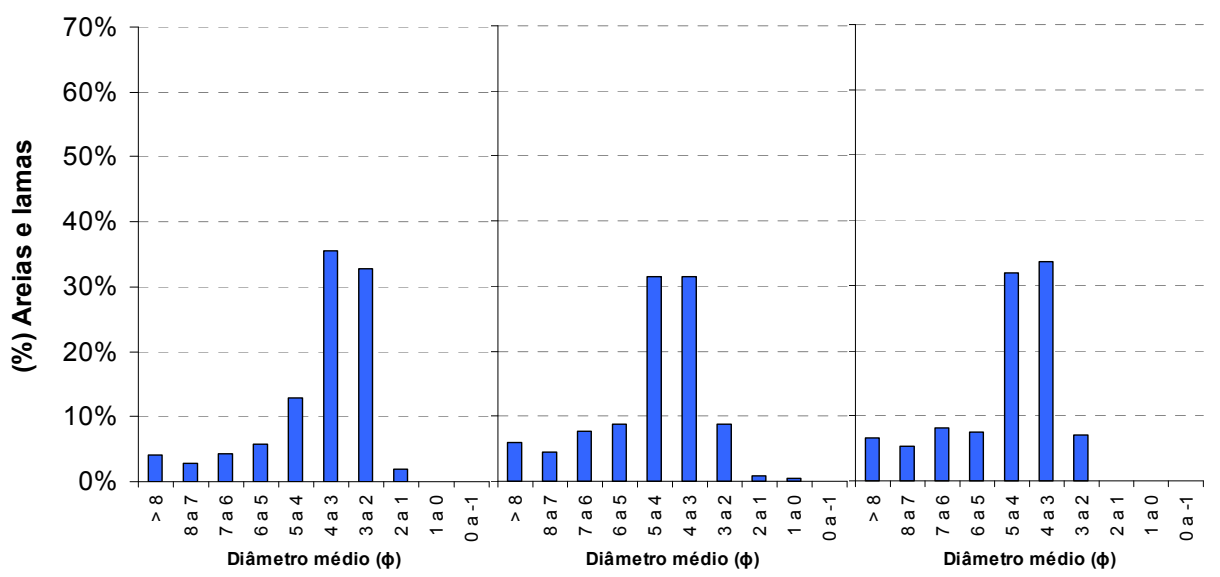

Fonte: Autor. 


\section{DISCUSSÃO}

Os resultados de diâmetro médio $\varphi$, SPT e $\mathrm{CaCO}_{3}$ apresentaram correlação na sondagem SP-02, observando-se para os maiores valores de $\varphi$, os menores de SPT e os maiores de $\mathrm{CaCO}_{3}$. Também na sondagem SP-05, o diâmetro médio $\varphi$ e o SPT estão correlacionados de modo semelhante ao observado na sondagem SP-02.

Entretanto, observaram-se diferenças entre as sondagens nos valores de SPT para sedimentos semelhantes granulométrica e estratigraficamente, com maior variabilidade e menores valores de SPT, de modo geral, na sondagem SP-02 em relação à SP-05.

Espera-se (não como regra) que os sedimentos basais ou porções basais dentro de um mesmo intervalo apresentem maiores valores de SPT em relação aos estratos superiores, devido principalmente, ao próprio peso da coluna sedimentar total sobre os sedimentos, e ainda, pela oscilação negativa do nível do mar nos últimos 7000 anos, com exposição subaérea dos sedimentos, expulsão da água intersticial e ressecamento, pela ação de dunas e “envelhecimento" (MASSAD, 2009). Tais observações foram verificadas na sondagem SP05, na qual, os valores de SPT, tanto para as areias quanto para as lamas, ficaram dentro dos padrões conhecidos na RMBS, com as areias apresentando números mais elevados nas porções inferiores (entre 10 e 40 no IA-1) e intermediárias (entre 13 e 38 no IA-2) do furo, bem como, maiores valores de SPT em direção à base de cada intervalo arenoso, enquanto os números de SPT das lamas foram sempre baixos (entre 1 e 3) nos três intervalos delimitados. Já para a sondagem SP-02, o padrão de SPT variou tanto dentro do mesmo intervalo quanto para intervalos distintos, ainda que com granulometria semelhante. Em alguns intervalos arenosos, nos quais houve uma variação no SPT dentro de um mesmo intervalo, especificamente no IA_2 (entre as cotas $-36,6 \mathrm{~m}$ e $-19,75 \mathrm{~m}$ ), anotaram-se valores de SPT entre 11 e 23 na porção basal do intervalo composto basicamente por areia fina (entre as cotas $-36,6 \mathrm{~m} \mathrm{e}-30 \mathrm{~m}$ ), decaindo para valores de SPT entre 4 e 15 entre as cotas $-30 \mathrm{~m}$ e $-19,75 \mathrm{~m}$ (o qual varia entre areia fina e areia muito fina com presença de silte grosso).

Tem-se ainda, a variação de SPT entre intervalos distintos estratigraficamente, porem, compostos por sedimentos de granulometria semelhante, a qual é observada na comparação entre os intervalos arenosos 3 e 4 . Embora posicionado estratigraficamente acima, e, portanto, com peso do pacote sedimentar menor do que o IA_3, o IA_4 (entre as cotas -6,9 m e 6,9 m) apresentou valores de SPT entre 3 e 21, enquanto no intervalo arenoso 3 (entre as cotas -17,5 $\mathrm{m}$ e - $10,15 \mathrm{~m}$ ) composto por areia muito fina e areia fina o SPT variou entre 2 e 4, atribuindo-se ao fato do IA_4 ser composto basicamente por areia (100\% de areia na maioria 
das amostras) com melhor seleção granulométrica (livre de lamas), devido à possível exposição subaérea e ação de dunas (refletindo no retrabalhamento e seleção do material, ressecamento e compactação), enquanto no IA_3, ocorre a presença de sedimentos finos em meio às areias (até $25 \%$ de lamas) depositadas provavelmente em ambiente lagunar, resultando em depósitos pouco adensados e não drenados. Com isso, supõe-se que a variabilidade de SPT anotada na sondagem SP-02 e a relação desta com a granulometria foi influenciada por: 1) seleção dos grãos nos intervalos arenosos, com diminuição dos valores de SPT dentro de intervalos arenosos contendo lamas disseminadas, observado principalmente nas porções superiores do IA_2 e em todo o IA_3, com o aumento na carga de finos pela provável mudança no ambiente de sedimentação devido às oscilações relativas do nível do mar local (mudança de ambiente praial para ambiente lagunar); 2) peso da coluna sedimentar associada a variações nas taxas de sedimentação, com menor compactação nas porções superiores dentro de um mesmo intervalo; 3 ) exposição subaérea do IA_4 com ação de dunas e respectiva seleção e ressecamento dos sedimentos expostos. As lamas do IA_1 na sondagem SP-02, apresentaram valores de SPT maiores ( 8 a 6) em relação às lamas dos intervalos lamosos superiores (2 e 4), devido provavelmente aos mecanismos de carga-descarga, pelas variações do nível do mar e pela compactação devido ao peso dos sedimentos. Isto foi observado também na sondagem SP-05, entretanto, de maneira muito discreta, uma vez que o SPT do IL_1 variou entre 2 e 3, enquanto no IL_2 e IL_3 o SPT ficou entre 1 e 2.

Para a sondagem SP-02, na qual foram feitas ainda análises geoquímicas e radiométricas, a amostra -40 (IL_1) apresentou idade limite para o radiocarbono $(>43500)$ (possível MIS5e?), e $\delta^{13} \mathrm{C}_{\mathrm{PDB}}$ de $-29,6 \%$, indicativo de matéria orgânica de origem terrestre. A amostra -19 (IL_2) apresentou idade de 44890 AP (2б: 45580-44200) (MIS3) e $\delta^{13} \mathrm{C}_{\mathrm{PDB}}$ de $-24,4 \%$, indicativo de matéria orgânica de origem marinha e terrestre. Por fim, a amostra -7 (IL_3) apresentou idade de 40950 AP (2б: 41530-40300) (MIS3) e $\delta^{13} \mathrm{C}_{\mathrm{PDB}}$ de $-24,5 \%$, também indicando matéria orgânica de origem marinha e terrestre.

Quanto à proveniência dos sedimentos, nas amostras -39 e -40 há clara indicação de material terrígeno. Esta condição muda para condições mixohalinas a partir da amostra -38 e segue para todas as amostras, entretanto, a amostra -14 apresenta condições de ambiente marinho devido aos valores de $\delta^{13} \mathrm{C}$ e $\mathrm{N} / \mathrm{C}$.

A distribuição dos metais revela a existência de dois grupos principais, os quais podem ser associados com a mineralogia predominante. O primeiro grupo envolve $\mathrm{K}, \mathrm{Ba}, \mathrm{Sc}, \mathrm{Al}, \mathrm{Mg}$ e Sr, e pode ser associado à dominância de minerais argilosos, enquanto o segundo grupo, composto por $\mathrm{Fe}, \mathrm{Ti}, \mathrm{Cr}, \mathrm{V}, \mathrm{Mn}, \mathrm{Cu}, \mathrm{Ni}$ e $\mathrm{Zn}$, corresponde aos elementos principais 
associados a óxidos. O cálcio permanece isolado, presente como um elemento característico exclusivo biogênico. A distribuição da relação de metais ao longo da sequência sedimentar mostra um padrão distinto, quando consideradas as duas sequências lamosas. A sequência basal é rica em metais associados com óxidos, como Fe e Ti. De outro lado, elementos característicos de minerais argilosos (silicatos) como Al, K e Sc estão mais presentes na sequência lamosa intermediária. Neste contexto, e, tendo em vista outros dados geoquímicos, os sedimentos com mais óxidos correspondem à fácies terrestre, enquanto sedimentos com mais silicatos argilosos estão associados ao ambiente mixohalino, indicando a possibilidade de rochas-fonte distintas ou mudanças nas condições climáticas entre MIS5e e MIS3.

$\mathrm{Na}$ interpretação da estratigrafia da planície costeira de Santos (Figura 23), Suguio e Martin (1978a) reconheceram a existência de argilas transicionais no topo dos sedimentos pleistocênicos e abaixo dos depósitos holocênicos, localizados a profundidades entre 5 a 20 m. Estes depósitos aparentemente ocupam somente áreas distais da planície, as quais podem estar associadas com a localização da sondagem SP-02. Entretanto, sem reconhecer a possibilidade da transgressão em MIS3, estes autores indicaram a ocorrência de sedimentos mixohalinos posicionados entre a MIS5e e depósitos holocênicos.

Figura 23 - Perfil geológico esquemático da planície costeira na Baixada Santista.

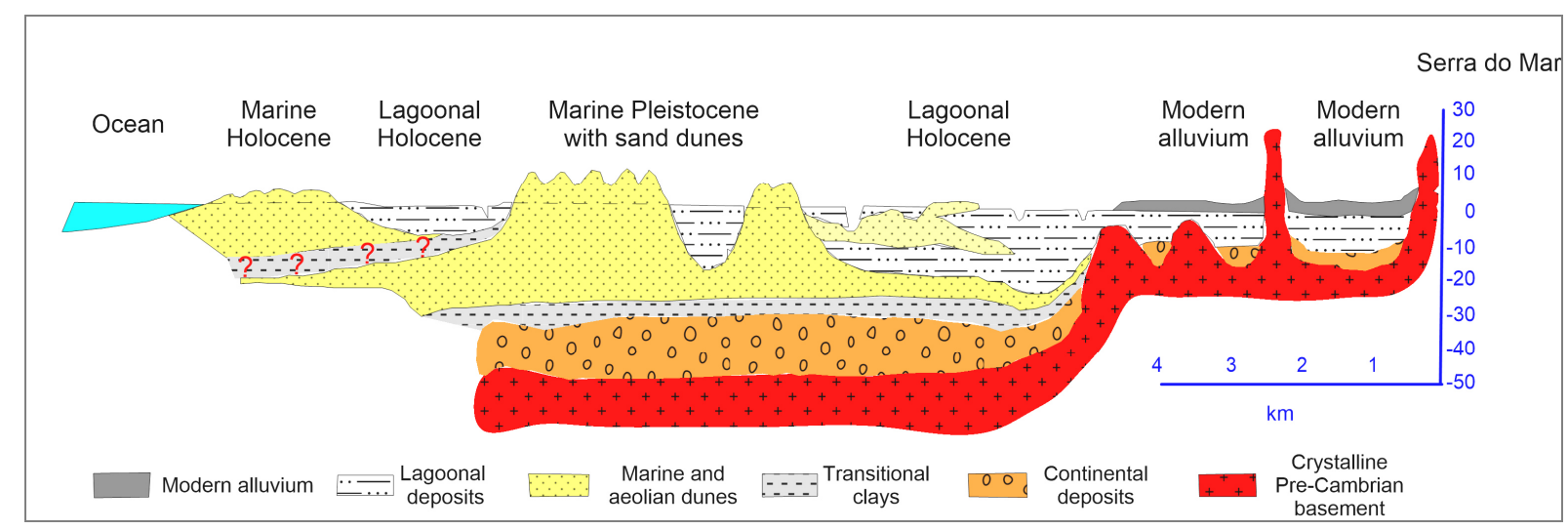

Fonte: Adaptado de Suguio e Martin (1978) apud Salvaterra et al. (2017).

Na sondagem SP-02, sedimentos do MIS5e estão depositados diretamente sobre solos de alteração de rochas do embasamento cristalino. Nesta sondagem, a sequência basal corresponde a sedimentos continentais que dão lugar a lama mixohalina (IL_1), a qual foi datada além do limite do radiocarbono. Com isso, a sequência de areia fina a areia muito fina, corresponde aos sedimentos regressivos depositados em nível marinho mais baixo. A segunda camada de lama datada entre 45000 e 40000 AP (MIS3) apresenta todas as características 
sedimentares e geoquímicas que apontam deposição em ambiente mixohalino. Entre 43000 e 42000 AP houve mudança nas características ambientais, indicada pela relação $\ln (\mathrm{Fe} / \mathrm{K})$, altos valores de $\delta^{13} \mathrm{C}_{\mathrm{PDB}}$ e $\mathrm{N} / \mathrm{C}$, apontando uma elevação do nível marinho ou uma mudança climática que teria levado a uma diminuição no intemperismo das rochas na área continental adjacente.

A ocorrência de depósitos transgressivos associados ao MIS3 em posições acima do previsto em curvas de isótopos de oxigênio (CHAPPELL; SHACKLETON, 1986) foi reportada em diversas áreas costeiras. No Texas foram identificados depósitos a $15 \mathrm{~m}$ de profundidade associados ao MIS3 (RODRIGUEZ et al., 2000). Na Carolina do Sul, foram reportados depósitos datados em MIS3 a $3 \mathrm{~m}$ de profundidade (DOAR III; KENDALL, 2017). Na Turquia, depósitos a profundidades de 39-40 m apresentaram idades de 53000 AP; entretanto, um forte componente tectônico não pode ser descartado devido à localidade localizar-se entre as placas Eurasiana, Africana e Arábica (DOĞAN et al., 2012). No sudeste da Ásia, depósitos costeiros apresentaram idades entre 40000 e 49000 AP a profundidades de $20 \mathrm{~m}$, possivelmente associados a um evento transgressivo durante o MIS3 (ZHAO et al., 2008). Na China, um regime tectônico específico foi proposto para explicar a ocorrência de depósitos associados ao MIS3 no Delta Changjiang, entretanto, mesmo retirando-se o tectonismo, tais depósitos MIS3 seriam encontrados a profundidades de $10 \mathrm{~m}$ (ZHAO et al., 2008). Ainda no sudeste Asiático, a possibilidade de depósitos associados ao MIS3 foi observada no Vietnam (HANEBUTH et al., 2006).

No sudeste do Brasil, De Mahiques et al. (2011) e Silva et al. (2014b) foram os primeiros autores a publicar referências sobre a transgressão MIS3, representada por depósitos mixohalinos/lagunares, localizados próximos ao nível marinho atual.

Próximo à área de estudo, no canal de São Sebastião (Estado de São Paulo), De Mahiques et al. (2011) descreveram uma transição completa de ambiente mixohalino para terrestre, baseado em datações por radiocarbono de foraminíferos e matéria orgânica com idades entre 39000 e 24000 AP Na região de Maricá (Estado do Rio de Janeiro), Silva et al. (2014b) descreveu a formação de uma barreira arenosa com idades entre 48000 e 45000 AP, depositada sobre sedimentos lagunares.

A reunião de dados obtidos por De Mahiques et al. (2011), Silva et al. (2014b) e neste trabalho apresenta um cenário (Figura 24), não para uma curva de nível marinho para o período entre 50000 e $40000 \mathrm{AP}$, mas para a posição, relativa ao nível marinho presente, de ambientes mixohalinos, sugerindo uma tendência de subida do nível marinho neste período. 
Importante notar a ocorrência de outros eventos geológicos, como a tectônica quaternária tardia (RICCOMINI, 1989; RICCOMINI; ASSUNÇÃO, 1999; WALKER et al., 2016), que devem ser considerados no caso da construção de curvas do nível marinho para a região.

Os dados aqui apresentados estão de acordo com as conclusões sobre as oscilações climáticas de curto prazo que ocorreram na primeira metade do MIS3 (FRIGOLA et al., 2012; SIDDALL et al., 2008). A transgressão aqui relatada pode estar associada a uma fase de elevação do nível do mar entre os eventos Heinrich HE4 e HE5 (ARZ et al., 2007; GONZÁLEZ; DUPONT, 2009).

Figura 24 - Plotagem da dispersão das datações de sedimentos mixohalinos em profundidade. Em verde (De Mahiques et al., 2011), em azul (Silva et al., 2014b) e em vermelho este trabalho.

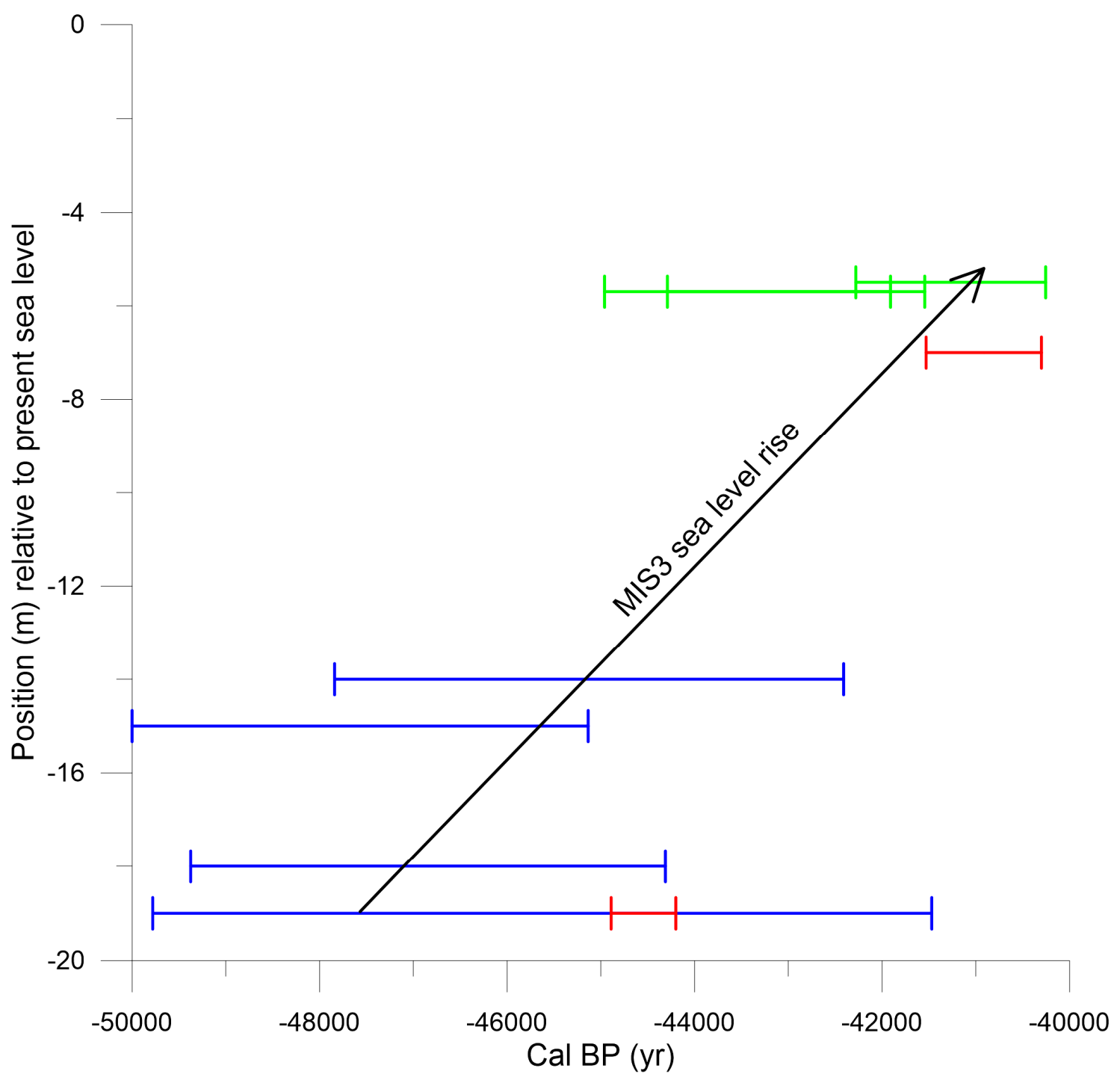

Fonte: Salvaterra et al. (2017). 
A integração das duas sondagens geotécnicas avaliadas neste trabalho (SP-02 e SP-05) com outras duas perfurações realizadas na mesma campanha (SP-03 e SP-04) permitiu a confecção de um perfil geológico local (Figura 25A e B). Futuramente, a adição e detalhamento de outros furos disponíveis nesta faixa costeira (não considerados neste estudo), pode indicar a ocorrência de depósitos sedimentares associados ao MIS3 de forma mais expressiva na região.

Figura 25 - (A) Locação das sondagens; (B) Perfil geológico entre as sondagens SP-02 e SP-05 ao longo da Rodovia dos Imigrantes - SP-160 em São Vicente/SP.

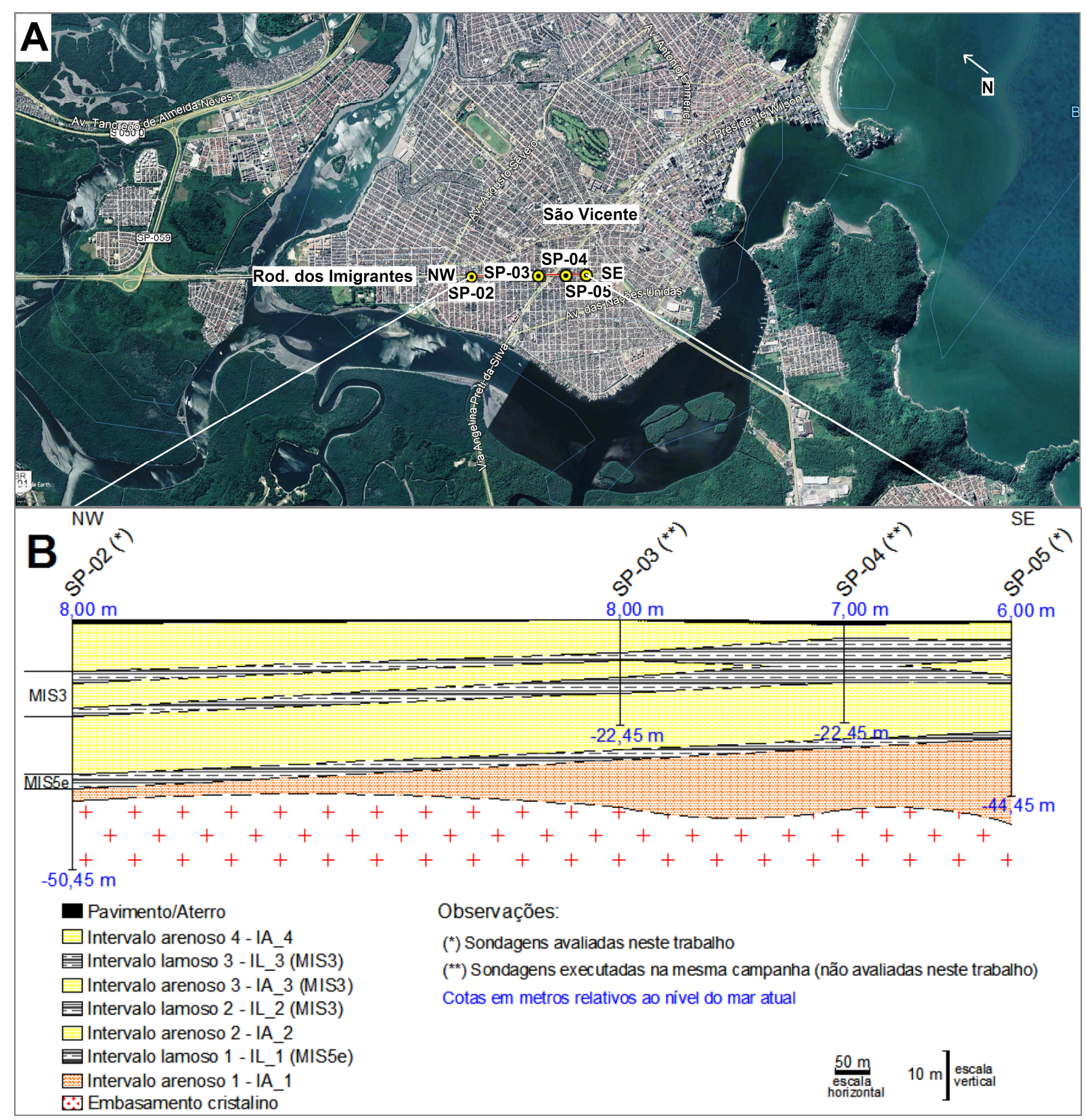

Fonte: (A) Modificado de GOOGLE INC. (2018); (B) Autor. 


\section{CONCLUSÕES}

Com base nos resultados de campo, descrição macroscópica e análises sedimentológicas das sondagens geotécnicas SP-02 e SP-05, e adicionalmente para a sondagem SP-02, análises geoquímicas e isotópicas, conclui-se que:

- A descrição macroscópica das sondagens permitiu o reconhecimento de três domínios geológico-geotécnicos distintos, sendo: (1) Solo de alteração de rocha (SAR) como produto da alteração de rochas do embasamento rochoso situado na base da sondagem SP-02, entre as cotas $-50,45 \mathrm{~m}$ e $-44,3 \mathrm{~m}$; (2) Sedimentos estuarinos (SE) pleistocênicos e holocênicos, entre as cotas $-44,3 \mathrm{~m}$ e $6,9 \mathrm{~m}$ na sondagem SP-02 e entre as cotas -44,45 m e 5,8 m na sondagem SP-05, e; (3) Pavimento asfáltico e aterro entre as cotas $6,9 \mathrm{~m}$ e $8,0 \mathrm{~m}$ na sondagem SP-02 e entre 5,8 $\mathrm{m}$ e $6 \mathrm{~m}$ na sondagem SP05 ;

- A macroscopia permitiu ainda, o reconhecimento e separação entre areias e lamas ao longo das duas perfurações, distinguindo-se quatro intervalos arenosos (IA_1, IA_2, IA_3, IA_4) e três intervalos lamosos (IL_1, IL_2, IL_3), da base para o topo de cada sondagem;

- Os valores de SPT medidos nas areias foram superiores aos das lamas nas duas sondagens, com os intervalos arenosos principais da sondagem SP-02 apresentando valores entre 2 e 23, e, 2 e 40 para a sondagem SP-05, estando os números mais elevados relacionados às areias com melhor seleção granulométrica, possivelmente pela ação de dunas, exposição subaérea, ressecamento e/ou posicionadas inferiormente na coluna estratigráfica (e/ou próximas à base de cada intervalo), ocorrendo, entretanto, quedas expressivas nos números de SPT em alguns intervalos arenosos (porção centro-superior do IA_2 e todo o IA_3) da sondagem SP-02 devido à presença de lamas nestas areias;

- Para as lamas, os valores de SPT são baixos nas duas sondagens (entre 1 e 8), apresentando, entretanto, pequeno aumento (6 e 8) no IL_1 da sondagem SP-02 pela maior compactação devido ao posicionamento estratigráfico, fato também observado na sondagem SP-05, só que de forma discreta;

- Datações por radiocarbono, proxies orgânicos e inorgânicos, têm sido usados para discriminar a transgressão MIS3 na planície costeira da Baixada Santista de um evento 
transgressivo mais antigo (MIS5e). Na idade indicada, entre 44890 e 40950 AP, um ambiente mixohalino desenvolveu-se entre 7 e 19 m abaixo do nível do mar atual, tendo ainda, proxies geoquímicos que sugerem uma transgressão marinha (ou mudança climática) entre 43000 e 42000 AP;

- Genericamente para a sondagem SP-02, os resultados de granulometria nos intervalos arenosos indicam a ocorrência predominante da fração areia fina, por vezes, com areia média a grossa associada (de forma predominante nas areias basais), e ainda, aparecimento de lamas disseminadas, principalmente nas areias intermediárias (IA_3 e IA_2), influenciando, inclusive, nos valores de SPT destes trechos. Já para as lamas, silte grosso aparece como fração principal, associado à areia muito fina, areia fina e silte médio a fino (ocorrendo ainda argila);

- Na sondagem SP-05, há o predomínio da fração areia fina nos intervalos arenosos, e secundariamente, areia muito fina, mas, diferentemente da SP-02, o material apresenta melhor seleção granulométrica, com discreto incremento de areia média e grossa na camada basal (IA_1), bem como, inexpressiva presença de lamas em todos os intervalos arenosos. Já para os intervalos lamosos, silte grosso, silte médio, silte fino aparecem associados à areia muito fina e areia fina (ocorrendo ainda argila), com valores de SPT baixos em todas as lamas;

- A diferença na relação dos metais entre duas sequências lamosas (IL_1 versus IL_2) aponta para características distintas entre ambiente terrestre versus mixohalino, associada com rochas-fonte ou condições climáticas;

- Trabalhos prévios, desenvolvidos na costa nordeste do Estado de São Paulo e na região costeira do Estado do Rio de Janeiro, no sudeste do Brasil, corroboram os resultados aqui apresentados e indicam a necessidade de uma revisão nas curvas do nível relativo do mar durante o Quaternário Tardio na costa sudoeste do Atlântico, assim como, para as planícies costeiras do sudeste do Brasil;

- Os dados obtidos convergem para a ocorrência de oscilações climáticas de curto prazo durante a primeira metade do MIS3. 


\section{REFERÊNCIAS}

ALMEIDA, F. F. M. DE. The system of continental rifts bordering the Santos Basin, Brazil. In: ANAIS DA ACADEMIA BRASILEIRA DE CIÊNCIAS, Rio de Janeiro, v. 48 (supl.), p. 15-26, 1976.

ALMEIDA, F. F. M. DE.; CARNEIRO, C. D. R. Origem e evolução da Serra do Mar. Revista Brasileira de Geociências, São Paulo, v. 28, n. 2, p.135-150, 1998.

ANGUlO, R. J.; LESSA, G. C.; SOUZA, M. C. DE. A critical review of mid- to lateHolocene sea-level fluctuations on the eastern Brazilian coastline. Quaternary Science Reviews, v. 25, n. 5-6, p. 486-506, 2006.

ARZ, H. W. et al. Dominant Northern Hemisphere climate control over millennial-scale glacial sea-level variability. Quaternary Science Reviews, v. 26, n. 3-4, p. 312-321, 2007.

ASSOCIAÇÃO BRASILEIRA DE GEOLOGIA DE ENGENHARIA. Boletim no 3: Manual de Sondagens. São Paulo: 5a ed. ABGE, 2013.

ASSOCIAÇÃO BRASILEIRA DE NORMAS TÉCNICAS. NBR 8036:1983: Programação de sondagens de simples reconhecimento dos solos para fundações de edifícios Procedimento. ABNT, 1983.

ASSOCIAÇÃO BRASILEIRA DE NORMAS TÉCNICAS. NBR 6502:1995: Rochas e solos - Terminologia. ABNT, 1995.

ASSOCIAÇÃO BRASILEIRA DE NORMAS TÉCNICAS. NBR 13441:1995: Rochas e Solos - Simbologia. ABNT, 1995.

ASSOCIAÇÃO BRASILEIRA DE NORMAS TÉCNICAS. NBR 6484:2001: Solo Sondagens de simples reconhecimento com SPT - Método de Ensaio. ABNT, 2001.

BLOTT, S. J.; PYE, K. GRADISTAT: A grain size distribution and statistics package for the analysis of unconsolidated sediments. Earth Surface Processes and Landforms, v. 26, n. 11, p. 1237-1248, 2001.

BUENO, E. Capitães do Brasil: a saga dos primeiros colonizadores. São Paulo: Objetiva, $1999,258 \mathrm{p}$.

CAMPANHA, G. A. C. et al. Análise do padrão de fraturamento mesozóico-cenozóico de bacias tafrogênicas continentais do sudeste do Brasil. In: SIMP. REG. GEOL., 5., 1985, São Paulo. Atas... São Paulo: SBG. v. 1, 1985, p. 337-350.

CAMPANHA, G. A. C.; ENS, H. H.; PONÇANO, W. L. Análise morfotectônica do planalto do Juqueriquerê, São Sebastião. Revista Brasileira de Geociências, São Paulo, v. 24, n. 1, p. 32-42, 1994. 
CANN, J. H. et al. Contemporany benthic foraminifera in Gulf St Vincent, South Australia, and a refined Late Pleistocene sea-level history. Australian Journal of Earth Sciences, v. 40, n. 2, p. 197-211, 1993.

CARON, F. et al. Características estratigráficas da barreira transgressiva holocênica na Praia dos Concheiros, planície costeira do Rio Grande do Sul, Brasil. In: XIII CONGRESSO DA ASSOCIAÇÃO BRASILEIRA DE ESTUDOS DO QUATERNÁRIO, Búzios. Resumos, 2011.

CHAPPELL, J.; SHACKLETON, N. J. Oxigen isotopes and sea level. Nature, 324, p. 137$140,1986$.

CHAPPELL, J. Sea level changes forced ice breakouts in the Last Glacial cycle: New results from coral terraces. Quaternary Science Reviews, v. 21, n. 10, p. 1229-1240, 2002.

CHEN, H-F. et al. The Ti/Al molar ratio as a new proxy for tracing sediment transportation processes and its application in aeolian events and sea level change in East Asia. Journal of Asian Earth Sciences, 73, p. 31-38, 2013.

COELHO, M. R. et al. Relação solo-relevo-substrato geológico nas restingas da planície costeira do Estado de São Paulo. Revista Brasileira de Ciência do Solo, Piracicaba, v. 34, n. 3, p. 833-846, 2010.

COMPANHIA DOCAS DO ESTADO DE SÃO PAULO. Resumo histórico. CODESP, 2017. Disponível em: <http://www.portodesantos.com.br/historia.php $>$. Acesso em: $10 / 01 / 2018$.

CONSULTORIA PAULISTA DE ESTUDOS AMBIENTAIS LTDA. - CPEA. Terminal Marítimo de Alemoa, RIMA - Relatório de Impacto Ambiental, Santos/SP, 2009. Mapa geológico da RMBS, 2009. Disponível em: $<$ http://licenciamento.ibama.gov.br/Porto/Terminal\%20Maritimo\%20de\%20Alemoa/EIARIMA/Figuras/figura_8_2_2_2_mapa_geologico_detalhe.pdf $>$. Acesso em: 16/01/2018.

CORRÊA, I. C. S. Les variations du niveau de la mer durant lês derniers 17.500 ans BP: l'exemple de la plate-forme continentale du Rio Grande do Sul-Brésil. Marine Geology, v. 130 (1-2), p. 163-178, 1996.

CUNHA, S. B.; GUERRA, A. J. T.. Geomorfologia do Brasil. $8^{\text {a }}$ ed. Rio de Janeiro: Bertrand, 2012, 392 p.

DE MAHIQUES, M. M. et al. Radiocarbon geochronology of the sediments of the São Paulo Bight (southern Brazilian upper margin). Anais da Academia Brasileira de Ciências, v. 83, n. 3, p. 817-834, 2011.

DE MAHIQUES, M. M. et al. Inorganic and organic geochemical fingerprinting of sediment sources and ocean circulation on a complex continental margin (São Paulo Bight, Brazil). Ocean Science, v. 13, p. 209-222, 2017.

DEPARTAMENTO DE ESTRADAS DE RODAGEM DO ESTADO DE SÃO PAULO DER. Mapa Rodoviário do Estado de São Paulo, São Paulo, 2006. Escala 1:1.000.000. 
DILLENBURG, S. R. et al. A barreira costeira de dunas altas no litoral médio do Rio Grande do Sul: um exemplo de barreira agradacional ou estacionária. Anais XI Congresso da Abequa, ABEQUA, Belém, Brasil. CD, 2007.

DILLENBURG, S.R. et al. Ground Penetration Radar (GPR) and Standard Penetration Test (SPT) records of a regressive barrier in southern Brazil. Journal of Coastal Research, Special Issue 64, p. 651-655, 2011.

DOAR III, W. R.; KENDALL, C. G. S. C. An analysis and comparison of observed Pleistocene South Carolina (USA) shoreline elevations with predicted elevations derived from Marine Oxygen Isotope Stages. Quaternary Research, v. 82, n. 1, p. 164-174, 2017.

DOĞAN, U. et al. MIS 5a and MIS 3 relatively high sea-level stands on the Hatay-Samandağ Coast, Eastern Mediterranean, Turkey. Quaternary International, 262, p. 65-79, 2012.

DORN, R. I. et al. Accelerator mass spectrometry radiocarbon dating of rock varnish. Geological Society of America Bulletin, v. 101, n. 11, p. 1363-1372, 1989.

DORNELES, L. O.; BECKER, J. E. G.; DILLENBURG, S. R. Variações granulométricas durante a progradação da barreira costeira holocênica no trecho Atlântida Sul - Rondinha Nova, RS. Gravel, Porto Alegre, v. 4, n. 1, p. 133-139, 2006.

ECORODOVIAS INFRAESTRUTURA E LOGÍSTICA S/A. Sistema Anchieta-Imigrantes, 2018. Disponível em: <http://www.ecovias.com.br/Institucional/Sistema-AnchietaImigrantes $>$. Acesso em: 10/01/2018.

EMILIANI, C. Pleistocene temperatures. The Journal of Geology, v. 63, n. 6, p. 538-578, 1955.

EMPRESA PAULISTA DE PLANEJAMENTO S/A. Região Metropolitana da Baixada Santista. GIP/CDI, 2017. Disponível em: <https://www.emplasa.sp.gov.br/RMBS $>$. Acesso em: 10/01/2018.

FRIGOLA, J. et al. A 500 kyr record of global sea-level oscillations in the Gulf of Lion, Mediterranean Sea: New insights into MIS 3 sea-level variability. Climate of the Past, 8, p. 1067-1077, 2012.

GONZÁLEZ, C.; DUPONT, L. M. Tropical salt marsh succession as sea-level indicator during Heinrich events. Quaternary Science Reviews, v. 28, n. 9-10, p. 939-946, 2009.

GOOGLE INC. Software Google Earth Pro, 2018.

GOVIN, A. et al. Distribution of major elements in Atlantic surface sediments $\left(36^{\circ} \mathrm{N}-49^{\circ} \mathrm{S}\right)$ : Imprint of terrigenous input and continental weathering. Geochemistry, Geophysics, Geosystems, v. 13, n. 1, 2012.

HAMMER, Ø; HARPER, D. A. T.; RYAN, P. D. PAST: Paleontological statistics software package for education and data analysis. Palaeontological Association. 2001. Available at: http://palaeo-electronica.org/2001_2001/past/issue2001_2001.htm [cited at Nov. 2016]. 
HANEBUTH, T. J. J. et al. Sea levels during late marine isotope stage 3 (or older?) reported from the Red River delta (northern Vietnam) and adjacent regions. Quaternary International, 145-146, p. 119-134, 2006.

HOGG, A. G., et al. SHCal13 Southern Hemisphere Calibration, 0-50,000 Years cal BP. Radiocarbon, v. 55, n. 4, p. 1889-1903, 2016.

INSTITUTO GEOGRÁFICO E CARTOGRÁFICO DO ESTADO DE SÃO PAULO - IGC. Divisão Municipal do Estado de São Paulo, São Paulo, 1998. Escala 1:1.000.000.

ISLA, F. I. Where was the sea-level 30-50,000 years ago? The Patagonian point of view. Quaternary of South America and Antarctic Peninsula, v. 6, p. 33-64, 1990.

ISLA, F. I.; SCHNACK, E. J. Sea level changes during Marine Isotopic Stage 3 (MIS 3) in Argentina. In: GASPARINI, G.M.; RABASSA, J.; DESCHAMPS, C.; TONNI, E. P. (eds.), Marine Isotope Stage 3 in Southern South America, 60 KA B.P.-30 KA B.P. Switzerland, Springer International Publishing, p. 147-154, 2016.

KLEIN, D. A.; DE MAHIQUES, M. M. Evidências de variações do nível relativo do mar durante o último ciclo glacial, na porção norte do Canal de São Sebastião, litoral norte do Estado de São Paulo. In: II CONGRESSO SOBRE PLANEJAMENTO E GESTÃO DAS ZONAS COSTEIRAS DOS PAÍSES DE EXPRESSÃO PORTUGUESA. Florianópolis, p. $1-5,2003$.

LAMBECK, K.; BARD, E. Sea-level change along the French Mediterranean coast for the past 30000 years. Earth and Planetary Science Letters, 175, p. 203-222, 2000.

LIMA, L. G. DE. Estratigrafia e evolução da barreira holocênica na Praia do Hermenegildo (RS). Dissertação de Mestrado. Programa de Pós-Graduação em Geociências. Instituto de Geociências. Universidade Federal do Rio Grande do Sul, Porto Alegre, 2008.

LIMA, L. G. DE. et al. Estratigrafia da zona de transição entre as fases transgressiva e regressiva de uma barreira costeira. In: XIII CONGRESSO DA ASSOCIAÇÃO BRASILEIRA DE ESTUDOS DO QUATERNÁRIO, Búzios. Resumos, 2011.

MARTIN, L. et al. Geoid change indications along the Brazilian coast during the last 7,000 years. In: V INTERNATIONAL CORAL REEF CONGRESS, 1985, Tahiti. Proceedings, v 3, p. 85-90, 1985.

MARTIN, L. et al. Fundamentos e reconstrução de antigos níveis marinhos do Quaternário. Boletim IG-USP, Publ. Esp, São Paulo, n. 4, p. 1-161, 1986.

MASSAD, F. Solos marinhos da Baixada Santista: características e propriedades geotécnicas. São Paulo: Oficina de Textos, 2009, 247 p.

MELLO, M. S.; PONÇANO, W. L. Gênese, distribuição e estratigrafia dos depósitos cenozóicos no Estado de São Paulo. São Paulo: Monografia 9, IPT, 1983. 
MELO, M. S. et al. Geologia e evolução do sistema de bacias tafrogênicas continentais do sudeste do Brasil. Revista Brasileira de Geociências, São Paulo, v. 15, n. 3, p. 193-201, 1985.

MUEHE, D. O litoral brasileiro e sua compartimentação. In: CUNHA, S.B.; GUERRA, A. J. T. Geomorfologia do Brasil. Rio de Janeiro: Bertand do Brasil, 1998, p. 273-349.

MURRAY-WALLACE, C. V. Pleistocene coastal stratigraphy, sea-level highstands and neotectonism of the southern Australian passive continental margin - a review. Journal of Quaternary Science, v. 17, n. 5-6, p. 469-489, 2002.

MURRAY-WALLACE, C. V. et al. Amino acid racemization and radiocarbon dating of interstadial marine strata (oxygen isotope stage 3), Gulf St. Vincent, South Australia. Marine Geology, v. 110, n. 1-2, p. 83-92, 1993.

NACE, T. E. et al. The role of North Brazil Current transport in the paleoclimate of the Brazilian Northeast margin and paleoceanography of the western tropical Atlantic during the late Quaternary. Palaeogeography, Palaeoclimatology, Palaeoecology, 415, p. 3-13, 2014.

PAHNKE, K. et al. 340,000-year centennial-scale marine record of Southern Hemisphere climatic oscillation. Science, v. 301, n. 5635, p. 948-952, 2003.

PISIAS, N. G. et al. High resolution stratigraphic correlation of benthic oxygen isotopic records spanning the last 300,000 years. Marine Geology, Elsevier, n. 56, p. 119-136, 1984.

PREFEITURA MUNICIPAL DE SÃO VICENTE. A história de São Vicente: o início da povoação, 2013. Disponível em: <http://www.saovicente.sp.gov.br/cidade-historia/>. Acesso em: 10/01/2018.

RABINEAU, M. et al. Paleo sea levels reconsidered from direct observation of paleoshoreline position during Glacial Maxima (for the last 500,000 yr). Earth and Planetary Science Letters, v. 252, n. 1-2, p. 119-137, 2006.

RAZIK, S. et al. Depositional provinces, dispersal, and origin of terrigenous sediments along the SE South American continental margin. Marine Geology, 363. p. 261-272, 2015.

RIBEIRO, M. C. S. et al. Evolução tectônica e denudacional da Serra do Mar (SE/Brasil) no limite entre o Cretáceo Superior e Paleoceno, utilizando análises de traços de fissão e UTh/He em apatitas. Revista Brasileira de Geomorfologia, v. 12, n. 3, p. 3-14, 2011.

RICCOMINI, C. O Rift Continental do sudeste do Brasil. Tese de Doutoramento. Instituto de Geociências. Universidade de São Paulo, São Paulo, 1989.

RICCOMINI, C.; ASSUMPÇÃO, M. Quaternary tectonics in Brazil. Episodes, v. 22, n. 3, p. 221-225, 1999.

RICCOMINI, C.; SANT'ANNA, L. G.; FERRARI, A. L. Evolução geológica do Rift Continental do sudeste do Brasil. In: MANTESSO NETO, V.; BARTORELLI, A.; CARNEIRO, C. D. R.; BRITO NEVES, B. B. Geologia do continente sul-americano: 
evolução da obra de Fernando Flávio Marques de Almeida. São Paulo: Beca. p. 383-405, 2004.

RODRIGUES, M. et al. Uma revisão histórica acerca do conhecimento sobre a sedimentação atual, em ambientes marinhos submersos, do Estado de São Paulo, Brasil. Revista Brasileira de Oceanografia, São Paulo, v. 47, n. 1, p. 91-106, 1999.

RODRIGUEZ, A. B. et al. Identification of a $-15 \mathrm{~m}$ Wisconsin shoreline on the Texas inner continental shelf. Palaeogeography, Palaeoclimatology, Palaeoecology, v. 158, n. 1-2, p. $25-43,2000$.

SALVADOR, E. D. Análise neotectônica da região do Vale do Rio Paraíba do Sul compreendida entre Cruzeiro (SP) e Itatiaia (RJ). Dissertação de Mestrado. Instituto de Geociências. Universidade de São Paulo, 1994, 129 p.

SALVATERRA, A. S. et al., Evidence of an Marine Isotope Stage 3 transgression at the Baixada Santista, south-eastern Brazilian coast. Brazilian Journal of Geology, v. 47, n. 4, p. 693-702, 2017.

SCHELLMANN, G.; RADTKE, U. Electron spin resonance (ESR) techniques applied to mollusc shells from South America (Chile, Argentina) and implications for palaeo sea-level curve. Quaternary Science Reviews, v. 16, n. 3-5, p. 465-475, 1997.

SCHMITZ, B. The $\mathrm{TiO}_{2} \mathrm{Al}_{2} \mathrm{O}_{3}$ ratio in the Cenozoic Bengal Abyssal Fan sediments and its use as a paleostream energy indicator. Marine Geology, v. 76, p. 195-206, 1987.

SIDDALL, M. et al. Marine isotope stage 3 sea level fluctuations: data synthesis and new outlook. Reviews of Geophysics, v. 46, n. 4, p. 1-29, 2008.

SILVA, A. L. C. DA. et al. Caracterização geomorfológica e sedimentar da planície costeira de Maricá (Rio de Janeiro). Revista Brasileira de Geomorfologia, v. 15, n. 2, p. 231-249, 2014a.

SILVA, A. L. C. DA. et al. Sedimentary architeture and depositional evolution of the Quaternary coastal plain of Maricá, Rio de Janeiro, Brazil. Brazilian Journal of Geology, v. 44, n. 2, p. 191-206, 2014 b.

SILVEIRA, J. D. Morfologia do litoral. In: AZEVEDO, A. DE (ed.) Brasil, a terra e o homem. São Paulo: Companhia Editora Nacional, 1964, p. 253-305.

SIMMS, A. R. et al. Revisiting marine isotope stage 3 and 5a (MIS3-5a) sea levels within the northwestern Gulf of Mexico. Global and Planetary Change, v. 66, n. 1-2, p. 100-111, 2009.

SIMON, M. H. et al. Eastern South African hydroclimate over the past 270,000 years. Scientific Reports, 5:18153, 2015.

SIQUEIRA, G. W. et al. Determinação da matéria orgânica e razões $\mathrm{C} / \mathrm{N}$ e $\mathrm{C} / \mathrm{S}$ em sedimentos de fundo do Estuário de Santos - SP/Brasil. Arq. Cien. Mar, Fortaleza. n. 39, p. 18-27, 2006. 
SOUSA, T. A. DE. Elementos terras raras como indicadores do aporte e proveniência sedimentar nos últimos 45 mil anos, Bacia de Santos - Brasil. Dissertação de Mestrado. Programa de Pós-Graduação em Geociências. Universidade Federal Fluminense, Niterói. 2017.

SOUZA, L. A. P. DE.; SILVA, R. F. DA; IYOMASA, W. S. Métodos de investigação. In: OLIVEIRA, A. M. S., BRITO, S. N. A. DE. (Ed.). Geologia de Engenharia. São Paulo: Associação Brasileira de Geologia de Engenharia, 1998, p. 163-196.

SOUZA, M. C. Estratigrafia e evolução das barreiras holocênicas paranaenses, sul do Brasil. In: CURITIBA, FEDERAL UNIVERSITY OF PARANÁ, p. 95, 2005.

SUGUIO, K. Geologia Sedimentar. São Paulo: Blucher, 2003, 400 p.

SUGUIO, K. Geologia do Quaternário e Mudanças Ambientais. São Paulo: Oficina de Textos, 2010, 408 p.

SUGUIO, K; BARCELOS, J. H. Quaternary sedimentary environments in Comprida Island, State of São Paulo, Brazil. In: Boletim IG, Instituto de Geociências USP, São Paulo, v. 9, p. 203-211, 1978.

SUGUIO, K; MARTIN, L. Formações quaternárias marinhas do litoral paulista e sulfluminense. Instituto de Geociências USP, Sociedade Brasileira de Geologia, São Paulo, $1978 \mathrm{a}$.

SUGUIO, K; MARTIN, L. Quaternary marine formations of the State of São Paulo and southern Rio de Janeiro. In: INTERNATIONAL SYMPOSIUM ON COASTAL EVOLUTION IN THE QUATERNARY, Sociedade Brasileira de Geologia, São Paulo, p. $1-55,1978 b$.

SUGUIO, K; MARTIN, L. Mapas geológicos na escala 1:100.000, cobrindo a costa paulista. São Paulo: DAEE, 1978c.

SUGUIO, K; MARTIN, L. Progress in research on Quaternary sea level changes and coastal evolution in Brazil. In: SYMPOSIUM ON VARIATIONS IN SEA LEVEL IN THE LAST 15,000 YEARS, MAGNITUDE AND CAUSES, Univ. South Caroline (USA), 1981.

SUGUIO, K; PETRI, S. Stratigraphy of the Iguape-Cananeia lagoonal region sedimentary deposits, São Paulo, Brazil. Part I: Field observations and grain size analysis. Boletim IGUSP, São Paulo, v. 4, p 1-20, 1973.

VARGAS, M. A Baixada Santista: suas bases físicas. Revista USP, São Paulo, n. 41, p. 1827, 1999.

VEIGA, F. A. Processos morfodinâmicos e sedimentológicos na plataforma continental rasa paranaense. In: CURITIBA, FEDERAL UNIVERSITY OF PARANÁ, p. 193, 2005. 
VICALVI, M. A.; COSTA, M. P. A.; KOWSMANN, R. Depressão de Abrolhos: uma paleolaguna holocênica na plataforma continental brasileira. Boletim Técnico da Petrobrás, 21, p. 279-286, 1978.

WALKER, R. T. et al. Rapid mantle-driven uplift along the Angolan margin in the Late Quaternary. Nature Geoscience, n. 9, p. 909-914, 2016.

YANEZ, D. G.; GONÇALVES, H. H. S. Parâmetros geotécnicos das argilas marinhas da região do Porto de Santos. In: COBRAMSEG: ENGENHARIA GEOTÉCNICA PARA O DESENVOLVIMENTO, INOVAÇÃO E SUSTENTABILIDADE, ABMS. São Paulo, 2010.

YIM, W. W. S. Radiocarbon dating and the reconstruction of late Quaternary sea-level changes in Hong Kong. Quaternary International, v. 55, n. 1, p. 77-91, 1999.

ZALÁN, P. V.; OLIVEIRA, J. A. B. DE. Origem e evolução estrutural do sistema de riftes cenozóicos do sudeste do Brasil. Boletim de Geociências da Petrobrás, v. 13, n. 2, p. 269$300,2005$.

ZHAO, B. et al. Marine sediment records and relative sea level change during late Pleistocene in the Changjiang delta area and adjacent continental shelf. Quaternary International, v. 186, n. 1, p. 164-172, 2008.

ZIEGLER, M. et al. Development of Middle Stone Age innovation linked to rapid climate change. Nature Communications, v. 4, n. 1905, 2013.

ZÜNDT, C. Baixada Santista: uso, expansão e ocupação do solo, estruturação de rede urbana regional e metropolização. In: CUNHA, J. M. P. (Org.). Novas Metrópoles Paulistas: população, vulnerabilidade e segregação. Campinas: NEPO/UNICAMP, 2006. 
ANEXO 
ANEXO A - Perfil sondagem geotécnica SP-02 


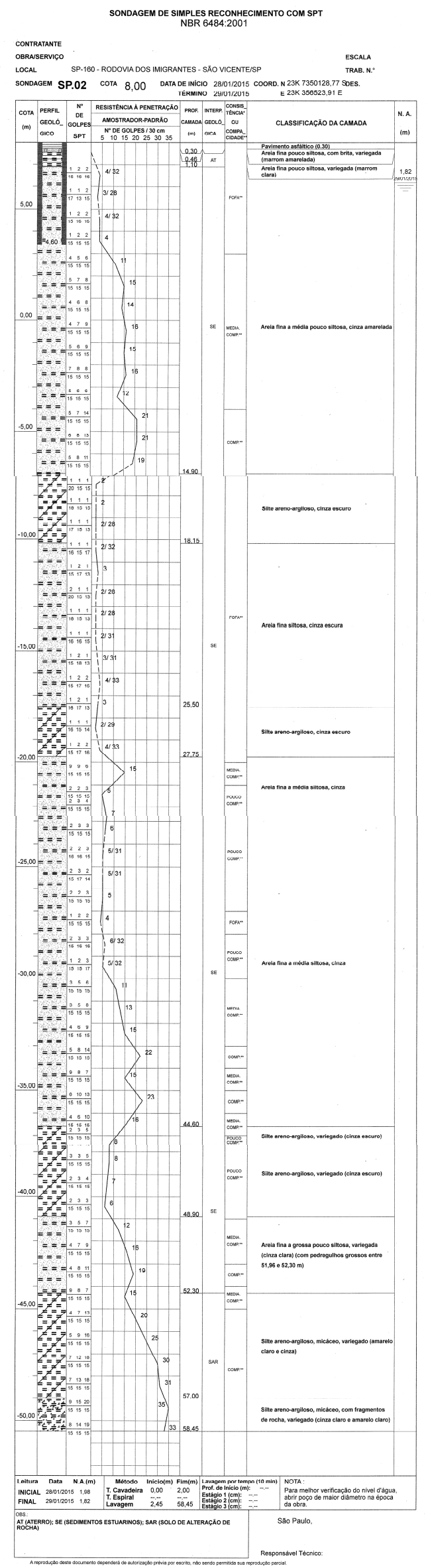


ANEXO B - Perfil sondagem geotécnica SP-05 


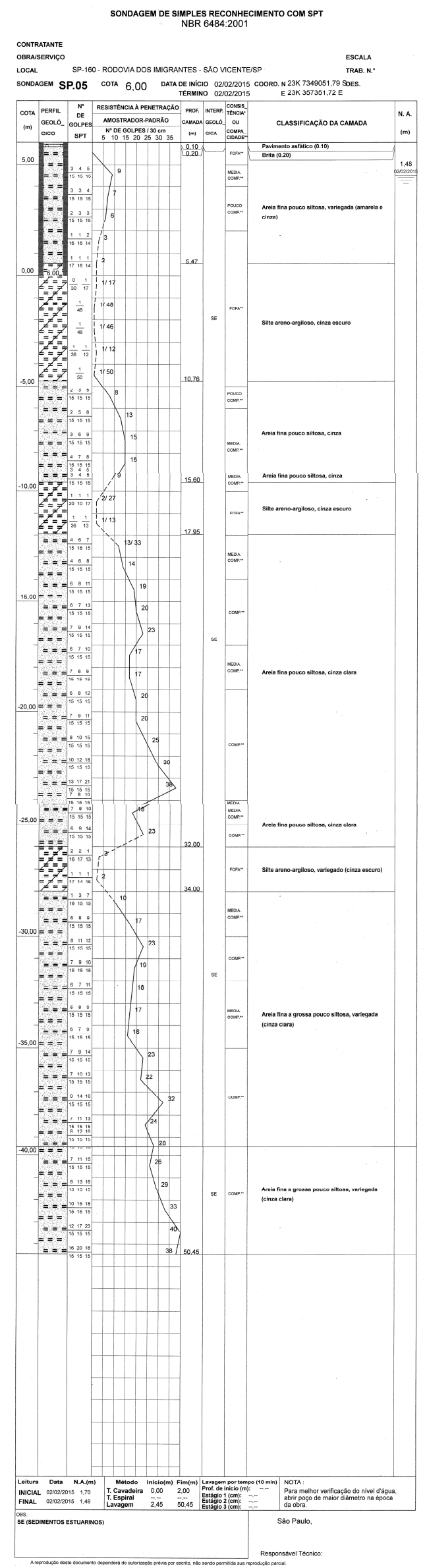

